\title{
Recent Trends and Prospects of Microbial Fuel Cell Technology for Energy Positive Wastewater Treatment Plants Treating Organic Waste Resources
}

\author{
Sunghoon Son ${ }^{1 \odot} \cdot{\text { Youngjin } \mathrm{Kim}^{2} \cdot \text { Myeong Woon } \mathrm{Kim}^{3++} \cdot \text { Sokhee P. Jung }}^{{ }^{1+\odot}}$ \\ 'Department of Environment and Energy Engineering, Chonnam National University, Gwangju, Republic of Korea, 61186 \\ ${ }^{2}$ Graduate School of Consulting, Kumoh National Institute of Technology, Gumi-si, Gyeongsangbuk-do, Republic of Korea, 39253 \\ ${ }^{3}$ Department of Energy and Environmental Engineering, Daejin University, Pocheon-si, Gyeonggi-do, Republic of Korea, 11159
}

(Received May 21, 2021; Revised October 12, 2021; Accepted October 12, 2021)

\begin{abstract}
Microbial fuel cell (MFC) technology is receiving a lot of attention recently as a promising technology for generating electricity by treating organic waste resources. Over the past 20 years, the MFC technology has made rapid progress: various research on system architectures, electrochemistry, materials, and microbiology has been conducted for developing practical ideas and fundamental principles. Recently, a lot of research on scaled-up systems for practical application is being conducted in the MFC field. In this review, materials, electrochemistry, system development and scale-up systems of MFCs studied so far are reviewed, and future prospects and directions of MFC technology are presented.
\end{abstract}

Keywords: microbial fuel cell, organic waste resource, wastewater treatment process, scale-up, water-energy nexus technology 


\title{
유기성 폐자원을 처리하는 에너지 공급형 하폐수처리장을 위한 미생물 연료전지 기술의 최근 동향 및 전망
}

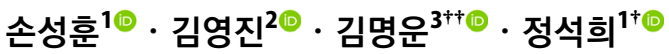 \\ ${ }^{1}$ 전남대학교 환경에너지공학과 광주캠퍼스, 61186 \\ 2금오공과대학교 컨설팅 대학원, 39253 \\ ${ }^{3}$ 대진대학교 환경에너지공학과, 11159
}

요약 : 미생물 연료 전지(MFC) 기술은 유기성 폐자원을 처리하며 전기를 생산하는 유망한 기술로서 최근 많은 각 광을 받고 있다. 지난 20 년간 $\mathrm{MFC}$ 기술은 급격한 발전을 이뤄왔다. 실용적인 기술 및 근본 원리의 발전을 위한 시스템 구조, 전기화학, 재료, 미생물학 등의 연구가 이뤄져 왔다. $\mathrm{MFC}$ 의 실용화를 위해 규모를 키운 반응조의 연 구도 최근 많이 진행되고 있다. 본 리뷰에서는 지금까지 연구된 MFC의 재료, 전기화학, 시스템 발전 및 스케일업 의 성과에 대해 살펴보고 이를 바탕으로 $\mathrm{MFC}$ 기술의 향후 전망과 방향을 제시하였다.

주제어 : 미생물 연료전지, 유기성 폐자원, 하폐수처리공정, 스케일업, 물-에너지 연계 기술

\section{1. 서론}

현재 인류는 지금까지 경험해 보지 못한 급격한 인구 증가 의 시대에 있으며, 이로 인해 안전한 수자원 확보의 많은 물을 소비한다. 2020년 기준 전 세계 인구는 약 78 억 명이며, 연간 소비된 물은 약 $4.0 \times 10^{12} \mathrm{~m}^{3}$, 물 관련 질병으로 인한 사망자 는 약 82.9만 명, 안전하지 않는 식수를 사용하는 사람은 약 20 억명이다. ${ }^{1,2)}$ 전세계 에너지 소비량은 13,508 Mtoe $(1.79 \times$ $10^{16} \mathrm{~W}, 1.57 \times 10^{14} \mathrm{kWh}, 2020$ 년 기준)이다. ${ }^{3)}$ 인구, 물 소비 량, 에너지 소비량 등이 매년 지속적으로 증가하는 현 상황에 서, 지속 가능한 지구환경을 위해 현 상황의 돌파구를 열어줄 물-에너지 연계(water-energy nexus) 기술들에 대한 수요는 나 날이 증가하고 있다.

미생물의 전기화학 현상을 응용한 미생물 전기화학 기술 (microbial electrochemical technology, MET)은 유망한 미래 물-에너지 연계 기술로 각광받고 있다. ${ }^{4,5)}$ 미생물이 전자를 체 외로 방출하여 전기를 발생하는 현상은 1911년 효모와 대장 균의 연구를 통해 Potter에 의해 발표됐다. ${ }^{6}$ 1931년에 영국 케임브리지 대학교에서는 스택 형태의 전기화학 장치에서 미 생물을 촉매로 사용하여 $0.2 \mathrm{~mA}$ 에서 $35 \mathrm{~V}$ 이상의 전압을 생 산했다. ${ }^{7}$ 1960년대에 미국 NASA는 장거리 우주 비행에서 유 기 폐기물을 전기로 변환하는 데 관심을 보이면서 연료 전지 에 대한 아이디어가 대중화됐다. 1962년 Rohrback 그룹에서 Clostridium butyricum 을 생체 물질로 사용하여 포도당 발효
에 의해 수소를 생산하는 최초의 생물학적 연료 전지를 설계 했다. ${ }^{89}$ 1966년 왕겨를 발효 시 생물학적 연료 전지에 사용 할 수 있는 에탄올과 같은 바이오 연료와 유용한 효소를 생 성한 것을 확인했고, 이를 통해 $6 \mathrm{~V}$ 에서 $40 \mathrm{~mA}$ 의 전류를 생 산했다. ${ }^{9}$ 나아가 1999년에 전자를 전극으로 전달하기 위해 매개체를 사용하지 않는 특정 전기화학적 활성 박테리아 종인 Shewanella putrefaciens 을 처음 발견했다. ${ }^{10)}$ 몇 년 후 Geobacter sulfurreducens를 이용하여 전기화학적 작용에 관 한 연구가 발표 후에 지구온난화를 일으키지 않는 청정에너지 원으로 $\mathrm{MFC}$ 의 연구가 본격적으로 시작됐다. ${ }^{10-12)}$

미생물 전기화학 시스템(microbial electrochemical system, $\mathrm{MES}$ )에는 여러 기술이 존재한다. 그중 가장 대표적인 기술은 미생물 연료전지(microbial fuel cell, MFC)는 음극(산화전극, anode)에 존재하는 미생물막을 통해 생분해성 기질을 산화하 고 전자가 음극으로 외부회로를 통해 양극(환원전극, cathode) 으로 이동하여 산소환원 반응을 통해 전류가 생성된다. ${ }^{13)}$

$\mathrm{MFC}$ 는 최근 10 년간 많은 연구가 진행되고 있다. 구글 학술 검색을 통해 확인한 결과 2010 년 약 1,120 개의 논문이 발표됐 으며, 이후 꾸준히 증가하여 2020년 약 5,090개의 논문이 발 표됐다(Fig.1). 이중 MFC scale-up의 연구는 연구가 활발히 진행함에 따라 2010 년 전체 MFC 논문의 $9.5 \%$ 의 비중을 차지 했지만, 2019년 $13.9 \%$ 까지 증가했다.

$\mathrm{MFC}$ 의 스케일 업은 몇 가지 제한 사항에 따라 손실이 발생 한다. ${ }^{8,14-16)}$ 첫 번째로 반응기의 부피가 증가할 때 성능이 비례 


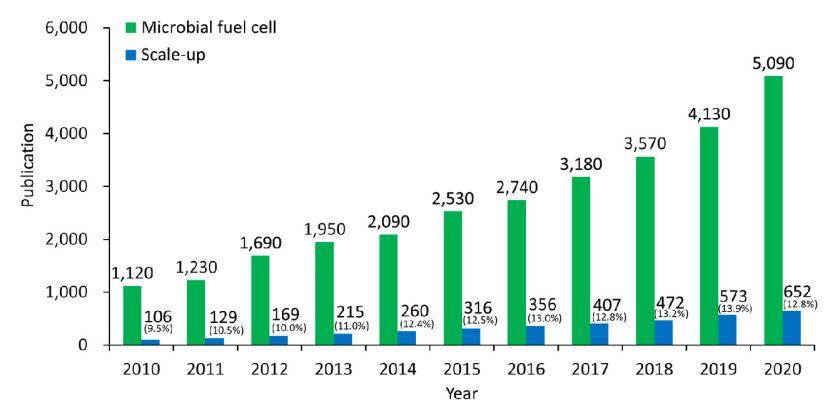

Fig. 1. Numbers of publications of the scientific literature on microbial fuel cells and microbial fuel cell scale-up (Google Scholar).
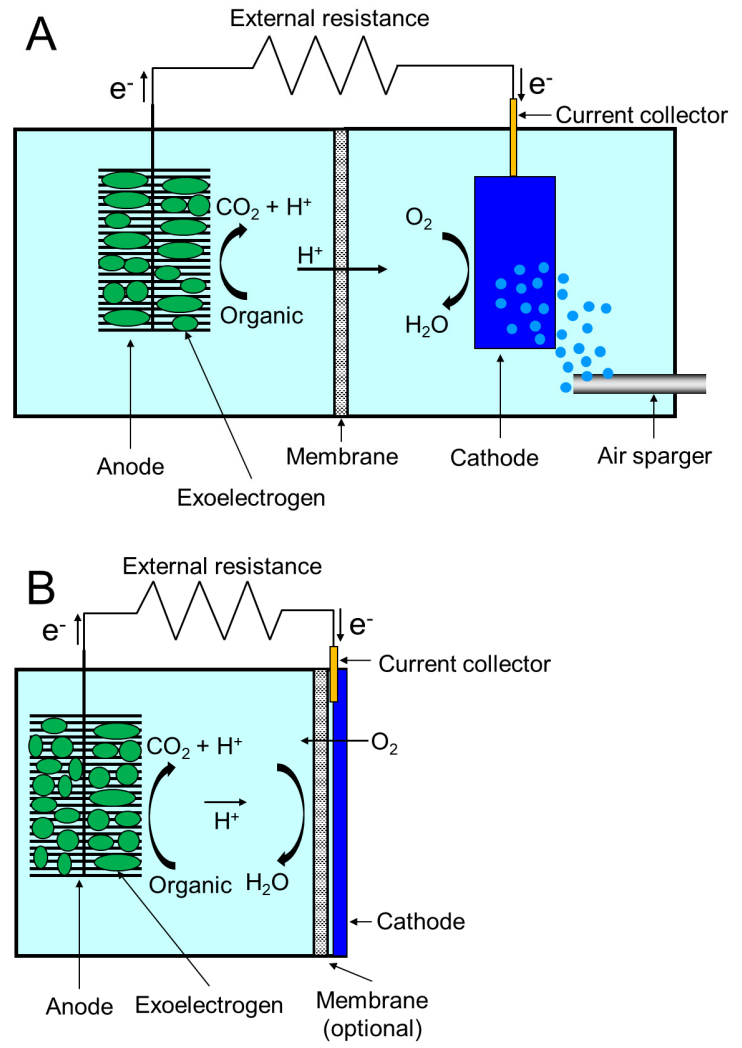

Fig. 2. Schematics of two chamber (A) and single chamber (B) microbial fuel cell.

적으로 증가하지 않는다. 즉, 스케일 업한 반응기의 실제 성능 은 저항, 전달 손실과 같은 여러 전기화학적 손실로 인하여 이론적인 값보다 낮다. 두 번째로, 성능을 향상시키기 위하여 여러 반응기를 연결하면 각 반응기 성능의 평준화와 같은 문 제가 발생한다. 이러한 문제는 실험실 규모의 반응기에서는 해결할 수 있지만, 스케일 업을 진행한 반응기에서는 아직 해 결되지 않았다. 그리하여 본 문헌은 $\mathrm{MFC}$ 의 원리, 지금까지 연구된 MFC 스케일 업 성능 비교, 실제 하수처리장에 접목한 사례 및 향후 $\mathrm{MFC}$ 의 전망에 관하여 논한다.

\section{MFC 재료의 최근 동향}

$\mathrm{MFC}$ 의 구성요소는 여러 가지가 있으나 그중 가장 중요한 구성요소는 음극(anode, 산화전극), 양극(cathode, 환원전극), 분리막이다. 음극은 미생물의 부착 및 산화반응을 하며, 양극 은 음극에서 방출된 전자를 수용하여 환원반응을 한다. 분리 막은 음극부(anode chamber)와 양극부(cathode chamber)를 물 리적으로 분리시켜 주는 역할을 하며, 분리막의 종류에 따라 양이온이나 음이온을 음극부나 양극부로 이동시키기도 한다. 또한, $\mathrm{MFC}$ 를 제작할 때 분리막을 사용하면 음극부, 양극부로 구분되고 이를 이실형 반응기(two chamber reactor)라 명칭하 며, 분리막을 사용하지 않으면 음극부, 양극부를 구분하지 않 고 일실형 반응기(single chamber reactor)라 한다. 이러한 음 극, 양극, 분리막은 여러 재료를 사용하여 제작한다. 각 재료 에 따라 $\mathrm{MFC}$ 의 전체적인 성능이 달라지며 이에 관한 연구가 활발하게 진행 중이다. 그리하여 이번 장에서는 $\mathrm{MFC}$ 의 가장 중요한 구성요소인 음극, 양극, 분리막의 재료의 최근 동향에 대해서 소개한다.

\section{1. 음극(Anode, 산화전극)}

\subsection{1. 음극의 전극 반응}

$\mathrm{MFC}$ 에서 생성되는 전기는 음극에서 방출되는 전자에 의존 하기 때문에 음극은 주요 구성 요소 중 하나이다. ${ }^{17)}$ 음극에서 전자방출균에 의해 기질이 분해되는 반응식은 다음과 같다. ${ }^{18-20)}$

$$
\begin{aligned}
& \text { Glucose: } \mathrm{C}_{6} \mathrm{H}_{12} \mathrm{O}_{6}+12 \mathrm{H}_{2} \mathrm{O} \rightarrow 6 \mathrm{HCO}_{3}^{-}+3 \mathrm{OH}^{+}+24 e^{-} \\
& \text {Acetate: } \mathrm{CH}_{3} \mathrm{COO}^{-}+4 \mathrm{H}_{2} \mathrm{O} \rightarrow 2 \mathrm{HCO}_{3}^{-}+9 \mathrm{H}^{+}+8 e^{-}
\end{aligned}
$$

위 식의 생성물인 전자는 음극의 미생물 막에서 방출되어 음극을 통해 전달되고 외부 회로를 통과하여 양극에 도달한 다. 그리고 기질에서 방출된 수소 이온은 내부용액이나 이온 막을 통과해 양극으로 이동하고 산소와 최종 전자 수용체와 결합하여 물을 형성하여 산화 환원 반응 과정을 통해 전류를 생산한다. 이러한 전기의 발생이 열역학법칙을 따른다면, 측 정된 음극의 전위는 Nernst식으로 계산이 가능하다. ${ }^{5)}$ 음극의 전위는 Table 1 에 나와 있다. ${ }^{5,21)}$

\subsection{2. 재료의 동향}

$\mathrm{MFC}$ 의 효율적인 음극의 재료는 강도, 화학적 안정성, 낮은 부식률, 높은 전기 전도성, 높은 표면적, 낮은 저항, 저렴한 가격, 강한 생체 적합성 등의 제한 조건이 있다. ${ }^{5,22-25)}$ 이러한 모든 특성을 가진 재료를 사용하는 것이 매우 바람직하지만 실제 사용 가능한 재료는 물리 화학적 특성과 미생물 부착 및 전자 전달에 대한 전도도에 따라 다르기 때문에 시스템에 맞게 선택을 해야 한다. 
Table 1. Anode and cathode theoretical potentials $\left(E^{\circ}\right)$ and real potentials in MFCs (E). All potentials are shown against SHE. Theoretical condition is STP. $E$ values are adjusted for $\mathrm{pH}=7, \mathrm{~T}=298.5 \mathrm{~K}$. Unless otherwise specified, chemical concentration is $1 \mathrm{~mol}$ or $1 \mathrm{~atm}^{21)}$

\begin{tabular}{|c|c|c|c|c|}
\hline Electrode & Reaction & $E^{0}(V)$ & conditions & $E(V)$ \\
\hline \multirow{2}{*}{ Anode } & $\mathrm{CH}_{3} \mathrm{COO}^{-}+4 \mathrm{H}_{2} \mathrm{O} \rightarrow 2 \mathrm{HCO}_{3}^{-}+9 \mathrm{H}^{+}+8 \mathrm{e}^{-}$ & 0.187 & $\begin{array}{c}\mathrm{CH}_{3} \mathrm{COO}^{-}=10 \mathrm{mM} \\
\mathrm{HCO}_{3}^{-}=20 \mathrm{mM}\end{array}$ & -0.289 \\
\hline & $\mathrm{C}_{6} \mathrm{H}_{12} \mathrm{O}_{6}+12 \mathrm{H}_{2} \mathrm{O} \rightarrow 6 \mathrm{HCO}_{3}^{-}+30 \mathrm{H}^{+}+24 \mathrm{e}^{-}$ & -0.001 & $\begin{array}{c}\mathrm{C}_{6} \mathrm{H}_{12} \mathrm{O}_{6}=10 \mathrm{mM} \\
\mathrm{HCO}_{3}{ }^{-}=20 \mathrm{mM}\end{array}$ & -0.539 \\
\hline \multirow{6}{*}{ Cathode } & $\mathrm{O}_{2}+2 \mathrm{H}^{+}+2 \mathrm{e}^{-} \rightarrow \mathrm{H}_{2} \mathrm{O}_{2}$ & 0.695 & Acidic, $\mathrm{pO}_{2}=0.2 \mathrm{~atm}$ & 0.260 \\
\hline & $\mathrm{H}_{2} \mathrm{O}_{2}+2 \mathrm{H}^{+}+2 \mathrm{e}^{-} \rightarrow 2 \mathrm{H}_{2} \mathrm{O}$ & 1.776 & Acidic, $\mathrm{pO}_{2}=0.2 \mathrm{~atm}$ & 1.335 \\
\hline & $\mathrm{O}_{2}+4 \mathrm{H}^{+}+4 \mathrm{e}^{-} \rightarrow 2 \mathrm{H}_{2} \mathrm{O}$ & 1.229 & Acidic, $\mathrm{pO}_{2}=0.2 \mathrm{~atm}$ & 0.805 \\
\hline & $\mathrm{O}_{2}+\mathrm{H}_{2} \mathrm{O}+2 \mathrm{e}^{-} \rightarrow \mathrm{HO}_{2}^{-}$ & -0.076 & Basic, $\mathrm{pO}_{2}=0.2 \mathrm{~atm}$ & -0.559 \\
\hline & $\mathrm{HO}_{2}^{-}+\mathrm{H}_{2} \mathrm{O}+2 \mathrm{e}^{-} \rightarrow 3 \mathrm{OH}^{-}$ & 0.878 & Basic, $\mathrm{pO}_{2}=0.2 \mathrm{~atm}$ & 0.432 \\
\hline & $\mathrm{O}_{2}+2 \mathrm{H}_{2} \mathrm{O}+4 \mathrm{e}^{-} \rightarrow 4 \mathrm{OH}^{-}$ & 0.401 & Basic, $\mathrm{pO}_{2}=0.2 \mathrm{~atm}$ & -0.023 \\
\hline
\end{tabular}

Table 2. Characteristics of anode materials in MFC

\begin{tabular}{|c|c|c|c|}
\hline Material & Advantage & Disadvantage & Ref. \\
\hline Graphite rod & $\begin{array}{l}\text { - Good electrical conductivity and chemical stability } \\
\text { - Relatively cheap }\end{array}$ & - Difficult to increase the surface area & 144) \\
\hline $\begin{array}{l}\text { Graphite fiber } \\
\text { brush }\end{array}$ & $\begin{array}{l}\text { - Higher specific surface areas } \\
\text { - Easy to produce }\end{array}$ & - Clogging & 239) \\
\hline Carbon cloth & - Large relative porosity & - Expensive & 240) \\
\hline Carbon paper & - Easy to connect wiring & $\begin{array}{l}\text { - Lack of durability } \\
\text { - fragile }\end{array}$ & 241) \\
\hline Carbon felt & - Large aperture & - Large resistance & 139) \\
\hline RVC & - Good electrical conductivity and plasticity & $\begin{array}{l}\text { - Large resistance } \\
\text { - Fragile }\end{array}$ & 143) \\
\hline $\begin{array}{l}\text { Metal/metal } \\
\text { oxides }\end{array}$ & $\begin{array}{l}\text { - High catalytic activity } \\
\text { - Low electrical resistance } \\
\text { - High-powered energy storage }\end{array}$ & $\begin{array}{l}\text { - Poor anti-corrosion and stability } \\
\text { - Redundant synthesis procedure }\end{array}$ & 242) \\
\hline CNTS & $\begin{array}{l}\text { - High elastic modulus, tensile strength } \\
\text { - Superior electrical resistance and catalytic activity } \\
\text { - Excellent energy density } \\
\text { - large specific surface area }\end{array}$ & $\begin{array}{l}\text { - Biotoxication } \\
\text { - Relatively high economic cost }\end{array}$ & 242) \\
\hline
\end{tabular}

$\mathrm{MFC}$ 에서 일반적으로 사용하는 음극의 재료는 탄소 종이 (carbon paper), 탄소 천(carbon cloth), 활성탄 천(activated carbon cloth), 탄소 펠트(carbon felt), 활성 탄소 섬유 펠트 (activated carbon fiber felt), 흑연 펠트(graphite felt), 탄소 섬 유 브러쉬(carbon fiber brush) 등과 같이 탄소 계열을 많이 사용하고 있다. ${ }^{25-29)}$ 이러한 탄소 계열의 물질의 대표적인 특 성은 안정적이고 상대적으로 저렴하며 전도성 및 화학적 안정 성에 의해 가장 널리 사용하고 있다. ${ }^{30,31)} \mathrm{MFC}$ 의 음극의 재료 로써 탄소 계열뿐만 아니라 금속 및 금속 산화물 재질도 사용 하며, 금속 재질은 탄소 계열보다 높은 전도도, 높은 전위창 (potential window) 및 높은 촉매 활성도를 보이지만, 탄소 계 열보다 부식되기 쉽다. ${ }^{32,33)}$ 대표적인 금속 재질의 음극은 스테 인리스 스틸(stainless steel), 팔라듐 $(\mathrm{Pd})$, 금 $(\mathrm{Au})$, 니켈 $(\mathrm{NiO})$,
망간 $\left(\mathrm{MnO}_{2}\right)$, 코발트 $\left(\mathrm{Co}_{\mathrm{x}} \mathrm{O}_{\mathrm{y}}\right)$, 티타늄 $\left(\mathrm{TiO}_{2}\right)$, 텅스텐 $\left(\mathrm{WO}_{3}\right)$ 과 이 금속들의 합금인 니켈망간산화물 $\left(\mathrm{Ni}_{0.1} \mathrm{Mn}_{0.9} \mathrm{O}_{1.45}\right)$, 니켈티 타늄(NiTi), 니켈텅스텐( $\left.\mathrm{NiWO}_{4}\right)$ 등을 사용한다. ${ }^{34-44)}$ 이러한 음극의 재료에 대한 특성은 Table 2에 나와 있다.

최근 음극 재료는 에너지 생성과 폐수 처리 문제에서 중요 한 중요성을 나타내는 두 가지 범주로 더 세분화된다. 이러한 음극 재료는 천연 바이오매스 기반 탄소 음극재, 복합 음극재, 그래핀계 물질로 구분할 수 있다. ${ }^{45)}$

첫 번째로 천연 바이오매스 기반 음극재는 천연 폐기물과 지속 가능성에서 가치 있는 바이오에너지를 생산하기 위한 잠재적인 친환경 방법을 제공한다. 식물 폐기물은 탄소 기반 음극에서 가장 자주 사용되는 천연 재료이며, 일반적으로 천 연 폐기물 유래 음극재로 알려져 있다. 이러한 식물 기반 탄소 
는 일반적으로 매우 높은 온도 $\left(1050^{\circ} \mathrm{C}\right)$ 에서 탄화가 이루어지 며, 탄화 전반에 걸친 수분 증발은 탄소 물질에서 다공성 구조 의 발달로 이어진다. ${ }^{46}$ 천연 폐기물을 이용한 사례로 빵 조각 을 사용하여 $3 \mathrm{D}$ 미세 다공성 물질을 음극재로 사용한 연구가 있다. 이 연구에서는 음극재의 표면적은 $295.07 \mathrm{~m}^{2} / \mathrm{g}$ 이었으며 이를 통해 $3134 \mathrm{~mW} / \mathrm{m}^{2}$ 의 최대 전력 밀도를 생산했다. 이는 carbon cloth를 사용한 음극보다 약 3 배 더 높은 결과이다. ${ }^{47)}$

두 번째로 복합 음극재는 최근 몇 년 동안 상당한 관심을 받았다. 복합 기반 재료는 일반적으로 두 가지 이상의 유형의 재료 또는 기본 재료의 개질 및 개선을 통해 시너지 효과를 얻기 위하여 활용되고 있다. 복합 음극재는 금속/금속 산화물, 전도성 고분자, 탄소계 복합재 등으로 분류된다. 음극에 박테 리아 부착량 증가 및 저항 손실 감소는 금속/금속 산화물-탄소 기반 재료 복합 재료에 의해 크게 영향을 받는다. ${ }^{48)}$ 금속 산화 물/탄소 복합 재료는 금속 기반 재료만으로는 부식의 문제와 탄소 기반 재료는 낮은 전도성 때문에 큰 관심을 받았다. 따라 서 복합재는 이 두 가지 요소를 해결하고 $\mathrm{MFC}$ 의 높은 성능을 위한 음극을 제공한다.

마지막으로 그래핀계 음극재는 전도성 $(7200 \mathrm{~S} / \mathrm{m})$, 표면적 $\left(2600 \mathrm{~m}^{2} / \mathrm{g}\right)$, 생체 적합성 및 박테리아 부착과 같은 현재 많은 문제를 충족하여 가장 유망한 재료로 간주된다. ${ }^{49)}$ 다른 금속 산화물 또는 전도성 고분자와 결합된 그래핀 기반 복합재는 높은 전자 이동 속도와 높은 전기 촉매 활성으로 인해 $\mathrm{MFC}$ 전극의 적용 범위를 넓힐 수 있는 돌파구를 제공한다. 현재의 에너지 공급 및 폐수 처리/오염 물질 제거 위기를 충족하기 위해서 MFC 접근 방식을 적용하기 위해 다른 재료와의 합성 을 통해 그래핀 기반 재료를 향상시키는 것을 고려해야 한다. 몇 가지 초기 연구는 그래핀으로 개질한 음극이 신호 분자를 분비하도록 박테리아 종을 자극할 수 있음을 보여주었다. 이 는 박테리아 성장을 향상시키고 전자 전달의 효율성을 증가시 키는 중간 분자로서 $\mathrm{MFC}$ 성능에 영향을 미쳤다. ${ }^{31}$ 또한, 그래 핀의 넓은 표면적은 기질 산화 및 계면 반응을 위한 더 많은 활성화 부위를 제공하여 저항 및 활성화 손실을 감소시켰다. 음극은 $\mathrm{MFC}$ 에서 중요한 역할을 하지만 가장 큰 문제점은 음극 재료의 비용이다. 또한, 음극의 적절한 설계와 크기는 박테리아 부착에 필요한 표면적을 제공하는 핵심 요소이다. 따라서 음극 재료의 선택은 높은 MFC 성능을 위한 이상적인 음극을 제작하는 데 중요한 단계이다. 종합적으로 현재 음극 의 재료로 가장 많은 연구가 되는 것은 각각의 단점을 최소화 하고 장점을 극대화하는 복합재이다. 이러한 음극재의 연구는

Table 3에 나와 있다.

\section{2. 양극(Cathode, 환원전극)}

$\mathrm{MFC}$ 의 주요 구성 요소 중 하나인 양극은 $\mathrm{MFC}$ 의 성능을 높이는 데 중요한 역할을 한다. MFC 양극에서 발생하는 주된 반응은 산소환원반응(oxygen reduction reaction, ORR)이다. ${ }^{50)}$
이러한 ORR이 일어나는 양극은 전류 수집체(current collector), 촉매층(catalyst layer), 확산층(diffusion layer)로 크게 3 개의 층으로 구분할 수 있다. 전류 수집체는 양극에서 발생한 전류 를 수집하고, 촉매를 부착시키기 위한 지지체로 사용한다. ${ }^{50-52)}$ 전류 수집체는 일반적으로 탄소 천을 주로 사용했지만 최근 탄소 천보다 저렴하고 높은 전도성을 가진 금속 계열의 망도 많이 사용하고 있으며, 대표적으로 사용하는 금속 계열의 망 은 스테인리스 스틸 망(stainless steel mesh, SSM)이다. ${ }^{50,53)}$ 촉 매층은 ORR반응이 일어나는 지점이며, 확산층은 양극의 산 소를 투과하고 방수의 기능을 가진다. 이러한 양극은 일반적 으로 바인더(binder)를 이용하여 촉매층과 확산층을 제조한다. 바인더는 일종의 접합제로써 촉매층과 전류 수집체의 결합을 용이하게 한다. ${ }^{54)}$ 가장 널리 사용된 바인더는 Nafion ${ }^{\mathrm{TM}}$ 이지만 높은 가격 때문에 상대적으로 저렴한 Polytetrafluoroethylen (PTFE), Poly (vinylidene fluoride) (PVDF)와 같은 바인더로 대체하여 사용하기도 한다. ${ }^{55-57)}$

\subsection{1. 양극의 전극 반응}

양극은 산소로 인하여 높은 전위값을 가지며, ORR반응은 2전자전달 반응과 4전자전달 반응이 있다. 양극에서 발생하는 ORR의 반응식은 다음과 같다. ${ }^{5,21,50)}$

$$
\begin{aligned}
& \text { 2전자: } \mathrm{O}_{2}+2 \mathrm{H}^{+}+2 e^{-} \rightarrow \mathrm{H}_{2} \mathrm{O}_{2} \text { (Acidic) } \\
& \text { 2전자: } \mathrm{H}_{2} \mathrm{O}_{2}+2 \mathrm{H}^{+}+2 e^{-} \rightarrow 2 \mathrm{H}_{2} \mathrm{O} \text { (Acidic) } \\
& \text { 4전자: } \mathrm{O}_{2}+4 \mathrm{H}^{+}+4 e^{-} \rightarrow 2 \mathrm{H}_{2} \mathrm{O} \text { (Acidic) } \\
& \text { 2전자: } \mathrm{O}_{2}+\mathrm{H}_{2} \mathrm{O}+2 e^{-} \rightarrow \mathrm{HO}_{2}^{-}+\mathrm{OH}^{-} \text {(Basic) } \\
& \text { 2전자: } \mathrm{HO}_{2}^{-}+\mathrm{H}_{2} \mathrm{O}+2 e^{-} \rightarrow 3 \mathrm{OH}^{-} \text {(Basic) } \\
& \text { 4전자: } \mathrm{O}_{2}+2 \mathrm{H}_{2} \mathrm{O}+4 e^{-} \rightarrow 4 \mathrm{OH}^{-} \text {(Basic) }
\end{aligned}
$$

대부분 $\mathrm{MFC}$ 의 반응기 전압은 약 $0.6 \mathrm{~V}$, 양극 전위는 0.3 $\mathrm{V}$ 의 값을 가진다(기질을 acetate 사용). ${ }^{5)}$ Table 1을 보면 acidic 에서 2전자전달 반응의 전위는 $0.260 \mathrm{~V}$ 이고, 이는 과산화수소 를 생산하는데 필요한 모든 에너지를 외부의 추가적인 공급 없이 MFC 자체적으로 생산하여 반응을 할 수 있다. ${ }^{57)}$ 즉, 대 부분의 $\mathrm{MFC}$ 는 4 전자전달 반응보다 과산화수소를 생성하는 2전자전달 반응이 주로 일어나며 추가적인 에너지 공급 없이 과산화수소를 생성할 수 있다. ${ }^{58)}$ 하지만 2전자전달 반응은 4 전자전달보다 느려 4전자전달 반응이 선호된다. ${ }^{49}$

\subsection{2 재료의 동향}

이상적인 ORR 촉매의 조건은 i) 높은 촉매 활성, ii) 높은 안정성, iii) 높은 선택성 및 iv) 저렴한 비용이다. ${ }^{59)}$ 일반적으 로 백금 $(\mathrm{Pt})$ 기반 촉매는 우수한 전기 촉매 활성으로 인해 
Table 3. List of biomass, composite material and graphene modified-based anode

\begin{tabular}{|c|c|c|c|c|c|c|}
\hline & Number & Materials & Organic substrate & Source of inoculum & $\begin{array}{l}\text { Power density } \\
\left(\mathrm{mW} / \mathrm{m}^{2}\right)\end{array}$ & Ref \\
\hline \multirow{12}{*}{$\begin{array}{l}\text { Biomass } \\
\text { material }\end{array}$} & 1 & Loofah sponge & Acetate & Pre-acclimated bacteria & 1090 & 243) \\
\hline & 2 & Bamboo charcoal & Acetate & Pre-acclimated bacteria & 1652 & 244) \\
\hline & 3 & Kapok fibers & Acetate & Activated sludge & 1738 & 245) \\
\hline & 4 & Coconut shell & Acetate & Sludge & 1069 & 246) \\
\hline & 5 & Chestnut shell & Acetate & Pre-acclimated bacteria & 759 & 247) \\
\hline & 6 & Municipal sludge & Lactate & Shewanella oneidensis MR-1 & 569 & 248) \\
\hline & 7 & Sewage sludge & Acetate & Pre-acclimated bacteria & 2228 & 249) \\
\hline & 8 & Cake & Acetate & Pre-acclimated bacteria & 1307 & 250) \\
\hline & 9 & Cotton textile & Acetate & Activated sludge & 931 & 251) \\
\hline & 10 & Neem wood & Simple glucose & Pre-acclimated bacteria & 256 & 252) \\
\hline & 11 & Coffee & Acetate & Domestic waste & 3927 & 253) \\
\hline & 12 & Corncob wastes & Acetate & Starch wastewater & 4990 & 154) \\
\hline \multirow{13}{*}{$\begin{array}{l}\text { Composite } \\
\text { material }\end{array}$} & 1 & $\mathrm{SnO}_{2} / \mathrm{rGO} / \mathrm{CC}$ & Phosphate buffer/glucose & Escherichia coli & 1624 & 254) \\
\hline & 2 & Mobil catalytic materials/GF & Synthetic wastewater & Anaerobic digester sludge & 71.8 & 255) \\
\hline & 3 & $\mathrm{MnO}_{2} / \mathrm{CF}$ & Phosphate buffer/acetate & MFCs effluent & 3580 & 256) \\
\hline & 4 & $\mathrm{Pd} / \mathrm{CC}$ & Phosphate buffer/acetate & Shewanella oneidensis MR-1 & 500 & 257) \\
\hline & 5 & PANI/Gr-CC & Phosphate buffer/acetate & MFCs effluent & 884 & 258) \\
\hline & 6 & $\mathrm{FeO} / \mathrm{CP}$ & Acetate & Strain breeding & 141 & 259) \\
\hline & 7 & $\mathrm{Mo}_{2} \mathrm{C} / \mathrm{CF}$ & Lactate & Shewanella putrefaciens CN32 & 1025 & 260) \\
\hline & 8 & Co/CoxOy/Graphite & Phosphate buffer/acetate & Food wastewater & 576 & 261) \\
\hline & 9 & PANI/CC & Phosphate buffer/acetate & MFCs effluent & 567 & 262) \\
\hline & 10 & $\mathrm{TiO}_{2} / \mathrm{SSM}$ & Acetate & MFCs effluent & 2870 & 39) \\
\hline & 11 & $\mathrm{Fe}_{3} \mathrm{O}_{4} / \mathrm{CC}$ & Simulated wastewater & Activated sludge & 728 & 263) \\
\hline & 12 & $\mathrm{NiO} / \mathrm{PANI} / \mathrm{CF}$ & Phosphate buffer/acetate & Anaerobic sludge & 1079 & 36) \\
\hline & 13 & PANI/SS plates & Phosphate buffer/acetate & Anaerobic mixed sludge & 780 & 36) \\
\hline \multirow{12}{*}{ Graphene } & 1 & GL/GP & Sodium acetate & Anaerobic sludge & 670 & 264) \\
\hline & 2 & GOA/GFB & Sodium acetate & Shewanella oneidensis MR-1 & 2520 & 266) \\
\hline & 3 & $\mathrm{rGO} / \mathrm{MnO}_{2} / \mathrm{CF}$ & Sodium acetate & MFC effluent & 2065 & 81) \\
\hline & 4 & GO/PANI/GP & Sodium acetate & Shewanella oneidensis MR-1 & 381 & 231) \\
\hline & 5 & DGMBE/CF & Glucose & Anaerobic sludge & 112.4 & 267) \\
\hline & 6 & GRF/GP & Lactate & Shewanella oneidensis MR-1 & 257 & 268) \\
\hline & 7 & $\mathrm{Gr} / \mathrm{CP}$ & Simulated wastewater & Anaerobic sludge & 2381 & 83) \\
\hline & 8 & $\mathrm{rGO} / \mathrm{Au} / \mathrm{CB}$ & Sodium acetate & Anaerobic sludge & 33.7 & 269) \\
\hline & 9 & GOZ/SSM & Simulated wastewater & Anaerobic sludge & 280 & 270) \\
\hline & 10 & $\mathrm{rGO} / \mathrm{PANI} / \mathrm{CC}$ & Sodium acetate & Wastewater & 306 & 271) \\
\hline & 12 & rGO-PAM & Sodium acetate & Sludge & 758 & 272) \\
\hline & 13 & CC-PDA-rGO & Acetate & Activated anaerobic sludge & 2047 & 273) \\
\hline
\end{tabular}

$\mathrm{GL}=$ Graphite layer; $\mathrm{GP}=$ Graphene particles; $\mathrm{GOA}=$ Graphene oxide aerogel; $\mathrm{GFB}=$ Graphite fiber brush; $\mathrm{rGO}=$ Reduced graphene oxide; $\mathrm{CF}=$ Carbon felt; $\mathrm{GO}=$ Graphene oxide; PANI = Polyaniline; $\mathrm{DGMBE}=$ Dual graphene modified bioelectrode; $\mathrm{GRF}=\mathrm{Graphene}$ riboflavin; $\mathrm{Gr}=$ Graphene; $\mathrm{CP}=$ Carbon paper; $\mathrm{CB}=$ Carbon brush; $\mathrm{GOZ}=$ Graphene oxide zeolite; $\mathrm{SSM}=$ Stainless steel mesh; $\mathrm{CC}=\mathrm{Carbon}$ cloth; $\mathrm{PAM}=$ Polyacrylamide; PDA-rGO = Polydopamine decorated reduced oxide graphene.

MFC 양극 ORR 촉매로 활용되어 왔다.,50-62) 그러나 백금 기 반 촉매의 높은 비용과 희소성으로 인해 새로운 촉매를 찾는 연구를 많이 진행했다. 그중 $\mathrm{Fe}, \mathrm{Co}, \mathrm{Ni}, \mathrm{Mn}$ 과 같은 전이 금속 이나 활성탄과 같은 탄소 기반 재료와 같은 물질이 높은 다공
성, 표면적, 전기 전도성 등 ORR 공정에 적합한 것으로 밝혀 졌다. ${ }^{61,63-66)}$ 그리하여 저렴하고 효율적인 양극을 위해 탄소 계 열과 전이 금속을 결합한 효율적인 촉매의 연구를 많이 진행 하고 있다. ${ }^{56,57,66)}$ 현재 대표적인 탄소 계열의 촉매는 흑연 
(graphite), 카본 블랙(carbon black), 활성탄(activated carbon, $\mathrm{AC}$ ), 탄소 나노튜브(carbon nanotube, CNT), 그래핀(graphene), 금속-질소-탄소 복합 촉매(metal-nitrogen-carbon complex, $\mathrm{M}-\mathrm{N}-\mathrm{C}$ ), 금속-유기 골격 촉매(metal-organic framework, MOF) 가 있다.

흑연은 비표면적, 생체 적합성, 화학적 안정성, 전자 전도성, 저렴한 비용 등으로 인해 양극 재료로 많이 사용된다. ${ }^{67,68)}$ 하 지만 처리하지 않은 흑연은 촉매 활성 부위가 적어 성능이 좋지 않다. ${ }^{69)}$ 표면적을 개선하기 위하여 질산으로 처리한 흑 연은 ORR을 향상시킨 연구가 있다. ${ }^{70)}$ 이 연구에 따르면 질산 으로 처리된 흑연의 열 활성화를 보고 했으며, 활성 흑연은 $\mathrm{OCP}$ 가 $40 \mathrm{mV}$ 증가했다. 이는 산소 및 질소와 같은 화학적 기능과 표면적이 증가했기 때문이다. 이후 최근 연구에 따르 면 흑연에 $\mathrm{CuO}$ 와 $\mathrm{ZnO}$ 을 합성하여 새로운 촉매를 개발했 다. ${ }^{71)}$ 결과는 $\mathrm{CuO} / \mathrm{ZnO} /$ 흑연 촉매는 대조군에 비하여 최대 전 력 밀도가 $32 \%$ 증가했다. 이러한 연구에도 불구하고 흑연은 낮은 반응성과 촉매적 특성으로 인하여 많이 사용되지 않는다.

카본 블랙은 탄화수소의 불완전한 열 산화로 인해 카본 블 랙이 형성된다. 카본 블랙 자체는 전기 촉매 특성을 가지고 있지만 금속 기반 촉매보다 낮은 성능을 가졌다. 또한, 카본 블랙은 불활성이며 촉매 활성이 매우 낮다. 카본 블랙의 전기 촉매 특성을 향상시키는 효과적인 방법 중 하나는 표면 활성 작용기를 통해 표면을 화학적으로 작용화 및 기능화하는 것이 다. 이 방법은 일반적으로 산을 사용하여 산 처리를 사용한다. 한 연구에서, 폴리아닐린(polyaniline, PANI)과 철-탈로시아닌 (iron-phthalocyanine, $\mathrm{FePc}$ )으로 기능화된 카본 블랙(PANI/C/ $\mathrm{FePc}$ )을 촉매로 개발했다. ${ }^{72)}$ 여기서 사용한 PANI는 $\mathrm{FePc}$ 를 위한 지지 금속물로 활용됐으며, 카본 블랙의 PANI 기능화는 $\mathrm{FePc}$ 의 흡수를 향상시켰다. 결과는 탄소 천에 백금 촉매(Pt/C) 를 사용하여 제작한 양극보다 약 $10 \%$ 더 높은 $630.5 \mathrm{~mW} / \mathrm{m}^{2}$ 의 최대 전력 밀도를 보였다. 또한, 최근 카본 블랙의 개질 연구에서 질소가 도핑된 카본 블랙(Vulcan XC-72R)을 산 처 리하여 질소 공급원으로 피라진아미드(pyrazinamide)로 기능 화했다. ${ }^{73)}$ XPS의 분석 결과는 graphitic-N, pyridinic-N 및 pyrrolic-N과 같은 다양한 형태의 N-기능기를 보였으며, 143 $\mathrm{m}^{2} / \mathrm{g}$ 의 표면적을 보였다. 이 촉매를 $\mathrm{MFC}$ 에 접목한 결과 371 $\mathrm{mW} / \mathrm{m}^{2}$ 의 최대 전력 밀도를 나타냈으며, 이는 $\mathrm{N}$-기능기의 차 이 때문이다.

활성탄은 표면적과 다공성을 향상시키는 탄소의 열처리로 생성한다. 다양한 기질을 사용할 수 있는 활성탄은 저렴한 가 격과 높은 표면적으로 $\mathrm{MFC}$ 의 양극 촉매로 가장 많이 사용하 고 있다. 하지만 활성탄은 낮은 전자 전도성 때문에 단일 촉매 로 사용하는 것보다 카본 블랙, 탄소 나노튜브 등과 같은 다른 전도성 탄소나 전이 금속을 혼합하여 사용한다. 활성탄 촉매 는 활성탄과 카본 블랙을 결합한 방법을 가장 널리 사용하고 있으며, 이는 $0.40 \mathrm{~S} / \mathrm{cm}$ 의 활성탄 전도도 보다 더 높은 0.53
$\mathrm{S} / \mathrm{cm}$ 의 전도도를 보였다. ${ }^{74)}$ 이 활성탄-카본 블랙 촉매를 $\mathrm{MFC}$ 에 접목한 결과 $\mathrm{Pt} / \mathrm{C}$ 양극보다 $41 \%$ 더 높은 $1900 \mathrm{~mW} / \mathrm{m}^{2}$ 의 최대 전력 밀도를 보였다. 이 외에도 활성탄에 질소를 도핑하 여 개질한 연구가 있다. ${ }^{75)}$ 이 연구는 활성탄을 코발트와 1,10 페난트롤린(1,10-phenanthroline)으로 $800^{\circ} \mathrm{C}$ 에서 개질하여 제 작한 양극(Co-N-C/AC)의 최대 전력 밀도가 $1,526 \mathrm{~mW} / \mathrm{m}^{2}$ 으 로 백금 환원 전극 $(\mathrm{Pt})$ 보다 $56 \%$ 높았다.

$\mathrm{MFC}$ 에 대한 탄소 나노튜브 기반 양극 촉매에 대한 많은 연구 논문이 있다. ${ }^{48,76,77)}$ 탄소 나노튜브는 우수한 전자 전도 성, 우수한 표면적 특성으로 인한 우수한 내식성을 갖추고 있 습니다. 탄소 나노튜브는 활성탄, 흑연, 카본 블랙과 마찬가지 로 산 처리를 사용한다. 그 외에 헤테로원자의 도핑 방법도 사용하는데 이 방법은 탄소 나노튜브의 ORR 활성을 향상시 키는 효과적인 방법으로 간주되며, $\mathrm{Co}, \mathrm{Fe}, \mathrm{Mn}$ 및 기타 전이 금속의 나노 입자도 탄소 나노튜브 표면에 침착되어 생성된 촉매는 다양한 구성의 $\mathrm{MFC}$ 에서 우수한 ORR 활성 및 성능을 나타냈다. ${ }^{78-80)}$ 탄소 나노튜브의 연구 중 탄소 천에 질소 도핑 한 탄소 나노튜브를 부착시킨 연구를 보면 최대 전력 밀도가 $542 \mathrm{~mW} / \mathrm{m}^{3}$ 으로 $\mathrm{Pt} / \mathrm{C}$ 보다 $8.6 \%$ 더 높은 성능을 보였으며, 이 는 탄소 나노뷰트의 우수한 전도도에 기인하며 질소 도핑에 의해서 성능이 더욱 증진됐다. ${ }^{81)}$

그래핀을 기반으로 하는 전기촉매는 우수한 전자 전도성, 넓은 표면적, 높은 흑연 특성, 화학적 및 물리적 기능화 용이 성으로 인해 큰 주목을 받고 있다. ${ }^{82)}$ 그러나 다른 탄소 물질과 마찬가지로 처리하지 않은 그래핀은 ORR 활성 기능기가 없 기 때문에 전기 촉매 응용 분야에 대해 불활성인 것으로 간주 된다. 전기음성도가 다른 다양한 헤테로원자로 그래핀을 화학 적으로 도핑하는 것은 그래핀을 우수한 전기촉매로 활용하는 효과적인 방법이다. $\mathrm{N}, \mathrm{B}, \mathrm{S}, \mathrm{P}$ 및 F와 같은 다양한 헤테로원 자는 그래핀 및 기타 탄소 재료에 대한 가능한 첨가제로 사용 된다. ${ }^{21)}$ 헤테로원자 도핑은 그래핀의 전하 밀도를 변경하여 산소의 잠재적 활성 부위를 생성한다. ${ }^{83)}$ 도핑된 그래핀은 전 자 전도성을 향상시켜 금속 나노입자 활성 부위로의 전자 이 동을 가속화하고, 이는 흡착된 산소와의 전자 교환에 긍정적 인 영향을 미친다. 다양한 형태의 그래핀은 환원그래핀옥사이 드(reduced graphene oxide, $\mathrm{rGO}$ ), 단층 및 다층 그래핀 시트, 그래핀 나노리본과 같은 ORR 촉매로 활용된다. ${ }^{84-86)}$ 최근 연 구 중 산화 그래핀과 구형 실리콘으로 기능화된 세틸트리메틸 암모늄 브로마이드(cetyltrimethyl ammonium bromide) 사이 의 정전기적 상호 작용을 활용한 후 알칼리 에칭을 통해 실리 콘을 제거하여 질소 도핑된 그래핀에 $\mathrm{Co}_{3} \mathrm{O}_{4}$ 를 합성했다. ${ }^{87)}$ 합 성된 그래핀은 $\mathrm{O}_{2}$ 분자당 3.91 개의 전자가 이동하여 알칼리성 매질에서 거의 유사한 ORR 활성으로 우수한 ORR 활성을 나 타냈으며, $0.59 \mathrm{~V}$ 의 $\mathrm{OCV}, 578 \mathrm{~mW} / \mathrm{m}^{2}$ 의 최대 전력 밀도를 생산했다.

금속-질소-탄소(M-N-C, M= Co, Fe, $\mathrm{Mn}$ 등)는 금속-대형 탄 
Table 4. List of various ORR catalysts for MFCs.

\begin{tabular}{|c|c|c|c|c|c|c|}
\hline & Number & Cathode Catalyst & Anode & Type of MFC & $\begin{array}{l}\text { Power density } \\
\left(\mathrm{mW} / \mathrm{m}^{2}\right)\end{array}$ & Ref \\
\hline \multirow{5}{*}{ Carbon black catalysts } & 1 & CoNPc/CB & Carbon paper & Dual & 64 & 274) \\
\hline & 2 & $\mathrm{ZrO}_{2} / \mathrm{CB}$ & Graphite brush & Single & 596 & 275) \\
\hline & 3 & $\mathrm{CuPc} / \mathrm{CB}$ & Carbon paper & Double & 118.2 & 276) \\
\hline & 4 & $\mathrm{CB} / \mathrm{AC}$ & Graphite brush & Single & 1560 & 277) \\
\hline & 5 & PANI-NF/CB & Carbon cloth & Single & 496 & 278) \\
\hline \multirow{5}{*}{$\begin{array}{l}\text { Activated carbon } \\
\text { catalysts }\end{array}$} & 1 & $A C$ & Carbon brush & Single & 892 & 279) \\
\hline & 2 & $A C$ & Carbon brush & Single & 2348 & 265) \\
\hline & 3 & Heat treated AC & Carbon brush & Single & 1400 & 280) \\
\hline & 4 & $A C$ & Graphite brush & Single & 1430 & 281) \\
\hline & 5 & $A C$ & Carbon brush & Single & 2151 & 282) \\
\hline \multirow{5}{*}{$\begin{array}{l}\text { Graphene }(\mathrm{Gr}) \text { based } \\
\text { catalysts }\end{array}$} & 1 & r-GO particles & Carbon brush & Double & $3.3 \mathrm{~W} / \mathrm{m}^{3}$ & 283) \\
\hline & 2 & $\mathrm{MnO}_{2} / \mathrm{Gr}$ & Carbon cloth & Single & $4.68 \mathrm{~W} / \mathrm{m}^{3}$ & 284) \\
\hline & 3 & $\mathrm{Pt}-\mathrm{Co} / \mathrm{Gr}$ & Carbon cloth & Single & 1378 & 285) \\
\hline & 4 & $\mathrm{Fe}_{3} \mathrm{O}_{4} / \mathrm{PEDOT} / \mathrm{rGO}$ & Carbon cloth & Single & 3525 & 286) \\
\hline & 5 & $\mathrm{MnO}_{2} / \mathrm{Gr}$ & Carbon felt & Single & 2084 & 287) \\
\hline \multirow{5}{*}{ CNT based catalysts } & 1 & Pt-Ni/MWCNTs & Carbon cloth & Single & 1220 & 288) \\
\hline & 2 & Pt/CNTs & Carbon felt & Single & 911 & 289) \\
\hline & 3 & CuSe/CNTs & Carbon cloth & Single & 425 & 290) \\
\hline & 4 & CNTs-dual layered & Fabric Graphite & Single & 207 & 291) \\
\hline & 5 & $\mathrm{MnO}_{2} / \mathrm{CNT}$ & Fabric Graphite & Single & 210 & 79) \\
\hline \multirow{10}{*}{$\begin{array}{c}\text { Etc } \\
(\mathrm{M}-\mathrm{N}-\mathrm{C}, \mathrm{MOF})\end{array}$} & 1 & N/Carbon powder & Carbon brush & Single chamber & 937 & 292) \\
\hline & 2 & $\mathrm{~N}-\mathrm{gr} / \mathrm{C}_{3} \mathrm{~N}_{4}$ & Carbon brush & Single chamber & 1618 & 293) \\
\hline & 3 & $\mathrm{CO}_{3} \mathrm{O}_{4}-\mathrm{N}-\mathrm{Gr}$ & Carbon granule & Dual Chamber & 1340 & 294) \\
\hline & 4 & Mesoporous N-carbon & Graphite brush & Single chamber & 979 & 295) \\
\hline & 5 & N/CNT & Carbon brush & Single chamber & 1600 & 296) \\
\hline & 6 & N/Carbon & Graphite brush & Single chamber & 1041 & 297) \\
\hline & 7 & $\mathrm{~N}$-carbon/Gr & Carbon brush & Single chamber & 1159 & 298) \\
\hline & 8 & $P-A C$ & Carbon felt & Single chamber & 1278 & 299) \\
\hline & 9 & P-Carbon & Graphite brush & Single chamber & 1312 & 285) \\
\hline & 10 & $\mathrm{~N}-\mathrm{S} / \mathrm{CNS}$ & Carbon brush & Dual Chamber & 1500 & 300) \\
\hline
\end{tabular}

소 혼합물의 간단한 열분해 $\left(400-1000^{\circ} \mathrm{C}\right)$ 에 의해 생성되어 금속이 질소 원자와 결합하는 활성 촉매를 생성할 수 있다. ${ }^{88)}$ 최초의 M-N-C 촉매의 ORR 활성은 촉매의 ORR 활성이 ${ }^{57} \mathrm{Fe}$ Mössbauer 분광법에 의해 N-도핑된 탄소에 배위결합된 $\mathrm{Fe}$ 원 자의 수에 직접적으로 의존하는 것으로 관찰됐다. ${ }^{89}$ 이후 $\mathrm{M}-\mathrm{N}-\mathrm{C}$ 에서 ORR 중간체의 흡착/탈착에서 $\mathrm{M}-\mathrm{N}-\mathrm{C}$ 활성 부위 의 메커니즘을 확인했다. ${ }^{90)}$ 이를 통해 M-N-C 촉매는 우수한 $\mathrm{ORR}$ 촉매로 제안됐으며, 최근 $\mathrm{MFC}$ 양극에 새로운 종류의 활성 촉매로 떠오르고 있다. ${ }^{91)}$ 최근 연구에서 $\mathrm{Fe}-\mathrm{N}-\mathrm{C}$ 촉매를 개발했는데, $\mathrm{N}$ 은 키토산 하이드로겔, $\mathrm{C}$ 는 활성탄을 이용했 다. ${ }^{92)}$ 실험의 결과는 $\mathrm{Fe}-\mathrm{N}-\mathrm{C}$ 촉매는 $630 \mathrm{mV}$ 의 OCV를 보였 으며, 약 120 시간 동안 $\mathrm{OCV}$ 의 변동이 거의 없어 우수한 안정
성을 보였다. 또한 $2.4 \mathrm{~W} / \mathrm{m}^{2}$ 의 최대 전력 밀도로 대조군인 활성탄 양극보다 약 $33 \%$ 더 높은 값이다.

금속-유기 골격 촉매(metal-organic framework, MOF)는 완 벽하게 배열된 방식으로 규칙적으로 배열된 금속 이온과 유기 리간드로 구성된다. ${ }^{93)}$ 금속 전구체는 $\mathrm{Fe}, \mathrm{Co}, \mathrm{Mn}, \mathrm{Ni}, \mathrm{Zn}$ 등을 사용하며, N, S와 같은 헤테로원자를 포함하는 유기 리간드를 사용한다. 가장 중요한 것은 $\mathrm{MOF}$ 에서 합성된 촉매는 높은 다공성 구조와 특정 촉매 적용에 대한 조정 가능한 특성을 가지고 있다. 대부분의 $\mathrm{MOF}$ 는 금속이온인 $\mathrm{Zn}^{2+}$ 와 리간드로 $\mathrm{N}$ 을 포함하는 2-methyl imidazole로부터 합성된다. 생성된 $\mathrm{MOF}$ 는 $\mathrm{Zn}$ 의 끓는점 이상에서 열분해되고 $\mathrm{MOF}$ 를 생성한다. 열분해 과정에서 $\mathrm{Zn}^{2+}$ 는 $\mathrm{Zn}$ 으로 전환 및 증발하여 불활성 가 
스에 의해 운반된다. 이후 $\mathrm{Zn}$ 원자가 0 인 촉매를 생성하고 동 시에 유기 리간드가 $\mathrm{N}$-도핑된 탄소로 분해 및 탄화된다. 대표 적인 MOF로 ZIF-8 (Zeolitic imidazolate framework-8)을 사용 하여 $\mathrm{MFC}$ 에 접목한 연구가 있다. ${ }^{94)}$ 그 결과 $2103 \mathrm{~mW} / \mathrm{m}^{2}$ 의 최대 전력 밀도를 생산했으며, ZIF-8에서 파생된 N-도핑된 탄 소는 우수한 흑연화, 전자 전도성을 가져서 $90 \%$ 이상의 COD 제거율, 110 시간 동안 운전하여 우수한 내구성이 평가됐다. 이 외에 ZIF-67을 이용한 연구도 있다. ${ }^{93)}$ 이 연구는 ZIF-67과 활성탄을 초음파로 결합하여 양극을 제작했다. 결과는 4203 $\mathrm{mW} / \mathrm{m}^{2}$ 의 최대 전력 밀도를 생산했으며, 이는 $50 \mathrm{mM} \mathrm{PBS}$, cubic 크기 $(4 \times 3 \mathrm{~cm})$ 을 사용한 $\mathrm{MFC}$ 기준으로 세계 최고의 성능을 달성했다. 지금까지 MFC 양극 촉매로 가장 많이 사용 한 물질은 활성탄이지만 낮은 전도성으로 인해 추가적인 물질 과 결합하여 사용하고 있다. 하지만 최근 금속-질소-탄소 촉매 나 금속-유기 골격 촉매가 새로운 양극 촉매로 각광받고 있으 며, 효율적인 양극의 촉매로 사용하기 위해 많은 연구를 진행 하고 있다.

\section{3. 막(Membrane)과 세퍼레이터(Separator)}

$\mathrm{MFC}$ 에서 물리적 분리기 역할을 하는 분리막은 음극부와 양극부 사이에 설치하며, 음극부에서 양극부로 기질의 확산을 효과적으로 방지한다. 또한, 음극부에서 양극부로 양성자의 수 송을 용이하게 하고 양극부의 산소를 음극부로 이동하는 것을 방지하거나 전자의 이동을 차단하여 단락 현상을 방지한다.95,90

분리막은 크게 2 가지로 구분되며, 이온 교환을 용이하게 하 는 이온막(membrane)과 전자나 양이온과 같은 물질의 이동을 차단하는 세퍼레이터(separator)가 있다. 세퍼레이터는 음극과 양극의 거리가 가까운 경우 전극의 단락 현상이 발생하기 때 문에 음극과 양극 사이에 삽입하여 단락 현상을 방지한 다. ${ }^{29,97,98)}$ 이온막은 일반적으로 양이온과 음이온을 교환할 수 있는 기능기를 포함하는 중합체 막이다. 이 막은 유사한 전하 이온(co-ion)을 차단하면서 일부 반대 전하 이온(counter-ion) 의 전달을 선택적으로 허용하여 이온을 이동시킨다.99)

이온막은 다공성, 비다공성 막으로 구분할 수 있다. ${ }^{100)}$ 다공 성 막은 나노여과(nanofiltration, NF), 한외여과(ultrafiltration, $\mathrm{UF}$ ), 미세여과(microfiltration, MF)으로 구분이 가능하며, 비 다공성 막은 양성자 교환막(proton exchange membrane, PEM), 음이온 교환막(anion exchange membrane, AEM), 양성자 교 환막(bipolar membrane, BPM), 역삼투압막(reverse or forward osmosis, RO or FO)이 있다. ${ }^{5,100,101)} \mathrm{PEM}$ 은 CEM (cation exchange membrane)이라고도 하며 막을 통해 양이온이 양극 부로 이동하게 하고, $\mathrm{AEM}$ 은 $\mathrm{PEM}$ 과는 다르게 음이온을 양극 부에서 음극부로 이동하게 한다. ${ }^{102)}$ 또한, $\mathrm{AEM}$ 은 막에서 부 착된 인산염 또는 탄산염과 같은 양전하는 양성자 운반체를 적용하여 양성자 이동을 촉진할 수 있다. ${ }^{103)} \mathrm{BPM}$ 은 음이온 교환층과 양이온 교환층의 구성으로 습윤접합 계면을 형성하
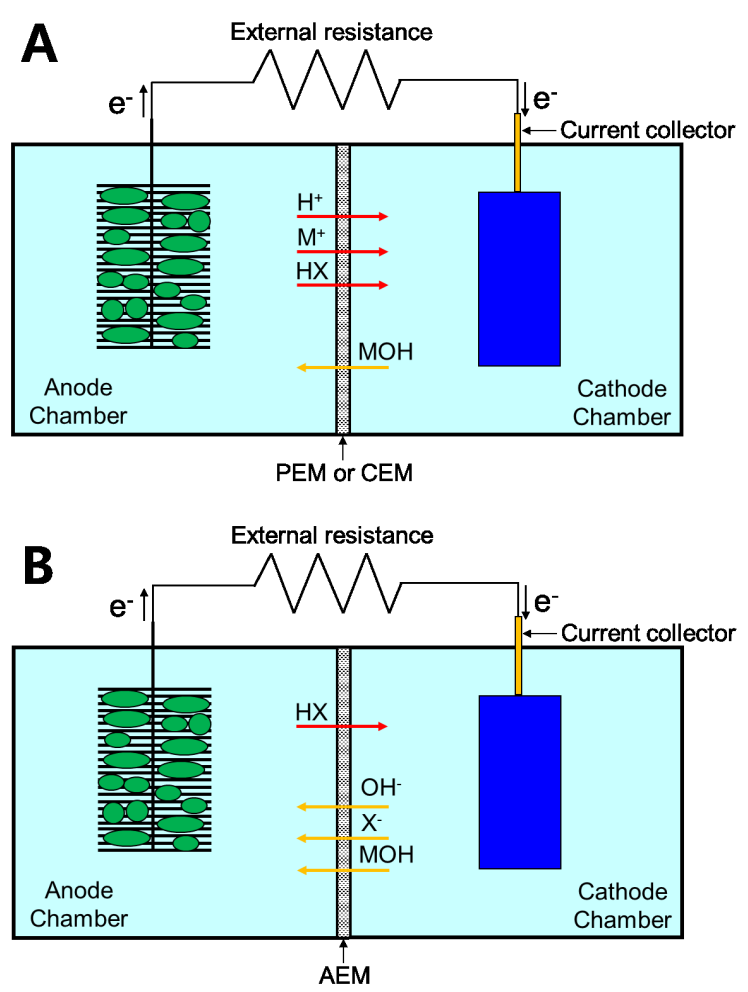

Fig. 3. Schematics of two-chamber MFC with PEM (A) and AEM (B). M: metal ion; $X$ : anion; PEM: proton exchange membrane; CEM: cation exchange membrane; AEM: anion exchange membrane.

는 막이며, BPM의 이온 전도도는 이온막을 가로지르는 이온 플럭스에 의한 것이 아니라 $\mathrm{PEM}$ 과 $\mathrm{AEM}$ 사이의 전이 영역 또는 표면에서 발생한 물 분해 반응을 통해 발생한다. ${ }^{102,104)}$ 이러한 이온막은 양성자보다 양이온의 전달 속도가 더 높다. 실제 하폐수에는 양이온이 양성자보다 $10^{5}$ 배 더 높은 농도로 존재하는데, 양이온의 전달 속도가 더 높으면 이온막과 양이 온이 결합하여 양성자의 이동을 억제할 수 있다. ${ }^{105-107)}$ 양성자 의 이동이 억제되면 음극부의 $\mathrm{pH}$ 가 감소하고 양극부의 $\mathrm{pH}$ 가 증가함에 따라 $\mathrm{MFC}$ 의 성능을 저하시킬 수 있다. 그에 따라 부직포와 같은 전도성이 없는 일반적인 막을 사용하기도 한 다. ${ }^{108-111)}$ 부직포와 같은 분리막을 사용하면 분리막의 세척이 용이하고 개질이 편하다는 장점이 있으며, 양이온이 많은 폐 수에서도 일정한 성능을 달성할 수 있다. ${ }^{112)}$

\subsection{1 최근 동향}

이온막은 MFC 시스템의 전체 비용과 성능에 상당한 영향 을 미치는 주요 구성 요소 중 하나이다. 하지만 내부 저항이 높은 이온막은 이온 교환 및 양성자 확산 감소로 인해 낮은 성능을 보이기 때문에 이온막은 시스템의 내부 저항에서 중요 한 역할을 한다. ${ }^{113)}$ 그리하여 이온막을 사용할 때 재질에 관계 없이 내부 저항, 물질 전달률, 전도도, 에너지 회수율, 이온 전도도, 내구성, 산소 확산 방지와 같은 몇 가지 주요 특징을 
Table 5. List of various types of membrane for MFCs.

\begin{tabular}{|c|c|c|c|c|c|c|}
\hline & Number & Cathode Catalyst & Anode & Membrane & $\begin{array}{l}\text { Power density } \\
\left(\mathrm{mW} / \mathrm{m}^{2}\right)\end{array}$ & Ref \\
\hline \multirow{5}{*}{$\begin{array}{c}\text { Cation Exchange } \\
\text { Membranes }\end{array}$} & 1 & $\mathrm{Pt} / \mathrm{C}$ & Graphite fiber brushes & Polyvinyl alcohol & 1220 & 301) \\
\hline & 2 & Carbon cloth & Carbon cloth & PDMS & $12.4 \mathrm{~mW} / \mathrm{m}^{3}$ & 302) \\
\hline & 3 & $\mathrm{Pt} / \mathrm{C}$ & Plain Carbon paper & SPEEK/CC/TAP & 81 & 303) \\
\hline & 4 & $\mathrm{Pt} / \mathrm{C}$ & Carbon cloth & SPSEBS + sulfonated $\mathrm{SiO}_{2}$ & 1209 & 304) \\
\hline & 5 & $\mathrm{Pt} / \mathrm{C}$ & Carbon cloth & SPSEBS + sulfonated $\mathrm{TiO}_{2}$ & 1345 & 305) \\
\hline \multirow{4}{*}{$\begin{array}{c}\text { Anion Exchange } \\
\text { membranes }\end{array}$} & 1 & $\mathrm{Pt} / \mathrm{C}$ & Carbon cloth & QPEEK & $58 \mathrm{~W} / \mathrm{m}^{3}$ & 306) \\
\hline & 2 & $\mathrm{Pt} / \mathrm{C}$ & Carbon cloth & QPEI & 612 & 307) \\
\hline & 3 & $\mathrm{Pt} / \mathrm{C}$ & Carbon cloth & QPSU/GO & 1036 & 308) \\
\hline & 4 & Pure graphite black & SS304 & RALEX AEM-PES & 58 & 309) \\
\hline
\end{tabular}

충족해야 한다. ${ }^{96,100,114)}$ 이뿐만 아니라 이온막과 관련된 주요 문제 중 하나는 산소와 기질이 반대 방향으로 크로스오버하는 것이다. 음극부에서 양극부로 기질이 이동하면 음극에 미생물 이 성장하여 ORR을 하지 못하게 되며, 양극에서 유기 기질이 산화되어 전력 효율이 감소한다. 따라서 $\mathrm{MFC}$ 를 효율적으로 운전하기 위해 기질과 산소의 균형을 유지하는 것이 중요하다. 막의 생물학적 요염은 막에서 중요한 문제이다. 이온막 표면 에 미생물이 부착되는 것을 이온막의 바이오파울링(biofouling) 이라 한다. 바이오파울링이 발생하면 이온막의 전자 전도성이 감소하기 때문에 바이오파울링을 줄이거나 제거하는 것이 중 요하다. ${ }^{115,116)}$ 이러한 바이오파울링을 줄이기 위해 부직포와 같은 전도성이 없는 물질에 미생물을 부착시킨 미생물 분리막 (microbial separator)의 연구가 진행 중이다. 미생물 분리막은 일종의 여과막으로서 이온의 이동뿐만 아니라 폐수 및 분자의 이동이 가능하고, 분리막에서 기질의 분해가 일어나 전력을 생산할 수 있다. 또한, 분리막에서 오염물질의 처리가 가능하 여 바이오파울링이 일어나지 않아 장시간 운전 시 긍정적인 성능을 보여줄 수 있다. ${ }^{117)}$

미생물 분리막은 현재 많은 연구가 되지 않아 추가적인 연 구가 필요하며, 향후 지속 가능한 분리막은 $\mathrm{MFC}$ 스케일업에 중요한 부분으로 자리매김할 것이다. 정리하면 $\mathrm{MFC}$ 에 적합 한 이온막은 우수한 이온 전도, 이온 선택성, 절연, 내구성, 생체 적합성, 화학적 안정성, 오염 등이 우수해야 하며 막힘에 민감하지 않고 비용이 저렴해야 한다. ${ }^{118)}$

\section{MFC 전기화학의 최근 동향}

일반적으로 $\mathrm{MFC}$ 의 성능을 평가하기 위해서 가장 많이 사용 하는 실험은 선형 강하 전압-전류법(linear sweep voltammetry, $\mathrm{LSV}$ ), 순환 전압전류법(cyclic voltammetry, CV), 전기화학 임 피던스 분광법(electrochemical impedance spectroscopy, EIS) 로 크게 3 가지가 있다.

$\mathrm{LSV}$ 는 $\mathrm{MFC}$ 에서 가장 기본적인 성능 평가로 측정하며 전
세계적으로 가장 많이 사용하는 실험이다. 이 실험은 전압 (voltage) 및 전위(potential) 또는 전류를 일정한 속도로 강하 하는 실험으로 전압 및 전위를 강하하면 전류를, 전류를 강하 하면 전압을 측정한다. 일반적으로 전극의 전위를 강하하는 실험을 $\mathrm{LSV}$, 반응기 전압을 강하하는 실험을 분극 실험 (polarization test)라고 명칭 한다. ${ }^{55,93,119,120)}$ 분극 실험은 LSV 의 일부분으로 반응기의 전압을 강하하고 그에 따른 전류를 측 정한다. 측정 결과를 이용하여 반응기의 분극 곡선(polarization curve), 최대 전력 밀도(maximum power density), 각 전극의 전위 등을 확인하고 반응기의 성능을 평가한다. 최대 전력 밀 도는 반응기에서 사용한 전극의 유효 면적이나 부피를 기반으 로 반응기에서 생산하는 전력을 확인할 수 있다. 또한, 전극 전위를 기반으로 각 전극 및 내부 저항을 계산할 수 있으며, 이 방법은 2017년 처음 사용되어 현재 세계적으로 반응기 성 능 평가의 지표로 많이 사용하고 있다. ${ }^{29,55,97,121-123)}$

$\mathrm{CV}$ 는 전기화학적 거동을 설명하기 위해 수행하는데 다시 말하면 가역적인 전기화학 활성을 기반으로 전자 이동 구성 요소를 식별 및 설명하기 위하여 수행한다. ${ }^{25,126)}$ 이러한 $\mathrm{CV}$ 는 일정한 범위를 지정한 뒤 전극의 전위를 일정한 속도로 주사하여 그에 따른 전류를 측정하며, 대표적으로 음극과 생 물막의 전자 전달 작용, 전극에서의 산화 및 환원반응 전위, 시간 경과에 따른 전극의 성능 평가 등을 정량적으로 비교하 는데 사용한다. ${ }^{126,127)}$

$\mathrm{MFC}$ 연구의 핵심 중 하나는 전력 생산을 제한하는 생물학 적 및 비생물학적 요인을 조사하는 것이다. 이러한 요소는 내 부 저항이나 전극의 임피던스(impedance)로 표현할 수 있 다. ${ }^{128)}$ 내부 저항은 위에서 기술한 것과 같이 분극 실험을 통 해서 계산이 가능하며 용액 저항, 전자 전달 저항, 확산 저항 3 가지로 구분할 수 있다. ${ }^{93,119,120)}$ 하지만 분극 실험을 통해 계 산하면 저항을 구분할 수 없기 때문에 세밀하고 정밀하게 분 석하기 위해 내부 용액 또는 전극의 계면 등에서 전하의 역학 을 조사하는 유용한 방법인 $\mathrm{EIS}$ 를 사용하여 분석한다. ${ }^{129)}$

쿨롱 효율 $\left(\mathrm{CE}_{(\mathrm{S} \mid \mathrm{E})}\right.$, coulombic efficiency, \%)은 기질로부터 
Table 6. Energy efficiency corrected using $-874.3 \mathrm{~kJ} / \mathrm{mol}$ heat of combustion.

\begin{tabular}{|c|c|c|c|c|}
\hline Number & $\begin{array}{l}\text { Heat of combustion in the literature } \\
\qquad(\mathrm{kJ} / \mathrm{mol})\end{array}$ & $\begin{array}{l}\text { Energy efficiency in the literature } \\
\qquad(\%)\end{array}$ & $\begin{array}{l}\text { Modified energy efficiency } \\
(\%)\end{array}$ & Ref \\
\hline \multirow{5}{*}{1} & -709.3 & 10.8 & 8.8 & \multirow{5}{*}{ 97) } \\
\hline & -709.3 & 10.2 & 8.3 & \\
\hline & -709.3 & 6.9 & 5.6 & \\
\hline & -709.3 & 7.9 & 6.4 & \\
\hline & -709.3 & 8.8 & 7.1 & \\
\hline \multirow{5}{*}{2} & -855.5 & 3 & 2.9 & \multirow{5}{*}{ 310) } \\
\hline & -855.5 & 10.4 & 10.2 & \\
\hline & -855.5 & 4.4 & 4.3 & \\
\hline & -855.5 & 2.7 & 2.6 & \\
\hline & -855.5 & 1 & 1.0 & \\
\hline 3 & -1139.94 & 13.7 & 17.9 & 311) \\
\hline 4 & -506.445 & 1.6 & 0.9 & 312) \\
\hline
\end{tabular}

음극으로 실제 전달된 전체 쿨롱의 비율로 정의된다. ${ }^{5,122)}$ 즉, $\mathrm{COD}$ 제거량으로부터 전환된 전류이다. 그리하여 $\mathrm{MFC}$ 의 운 전 시 시간에 따른 전류 생산량을 적분함으로써 쿨롱 효율을 계산한다. 이를 식으로 표현하면 다음과 같다.

$$
C E_{S \mid E}=\frac{M \int_{0}^{t} I d t}{F b v_{a n} \Delta C O D}
$$

$\mathrm{M}$ 은 32 (산소의 분자량), $\mathrm{F}$ 는 패러데이 상수 $\left(9.64853 \times 10^{4}\right.$ $\mathrm{C} / \mathrm{mol}$ ), $\mathrm{b}$ 는 4 (산소 1 몰당 교환되는 전자의 수), $\mathrm{van}$ 는 음극의 체적, $\triangle \mathrm{COD}(\mathrm{g}-\mathrm{COD})$ 는 운전 시 $\mathrm{COD}$ 의 변화, $\int_{0}^{\mathrm{t}} \mathrm{I} \mathrm{dt}$ 는 처 음부터 $\mathrm{t}$ 시간까지의 전류 생산량을 적분한 값이다. 여기서 $\mathrm{M}$ 과 $\mathrm{b}$ 가 상수이므로 이를 대입하여 식을 다시 계산하면 다음과 같이 간편하게 바뀐다.

$$
\mathrm{CE}_{\mathrm{S} \mid \mathrm{E}}=\frac{\int_{0}^{\mathrm{t}} \mathrm{I} \mathrm{dt}}{\mathrm{F} \mathrm{van}_{\mathrm{an}} \Delta \mathrm{COD} / 8}
$$

만약 $\mathrm{MFC}$ 를 운전 시 회분식이 아닌 연속흐름식으로 운전 하면 식은 다음과 같이 바뀐다.

$$
\mathrm{CE}_{S \mid \mathrm{E}}=\frac{\mathrm{M} \int_{0}^{\mathrm{t}} \mathrm{Idt}}{\mathrm{Fbq} \Delta \mathrm{COD}}=\frac{\int_{0}^{\mathrm{t}} \mathrm{Idt}}{\mathrm{Fq} \Delta \mathrm{COD} / 8}
$$

여기서 q는 유입수의 유속이고, $\triangle \mathrm{COD}$ 는 유입수와 유출수의 $\mathrm{COD}$ 의 차이 즉, 분해된 $\mathrm{COD}$ 의 농도이다. ${ }^{5)}$

$\mathrm{MFC}$ 의 성능을 평가하는 가장 중요한 요소는 기준 기술에 비해 에너지 회수 측면에서 평가하는 것이다. 에너지 효율 (EE, energy efficiency, \%)은 기질의 열소열으로부터 생산한 전력의 비율로 정의되며 식은 다음과 같다.

$$
\mathrm{EE}=\frac{\int_{0}^{\mathrm{t}} \mathrm{VIdt}}{\Delta \mathrm{Hn}}
$$

여기서 $\Delta \mathrm{H}$ 는 기질의 연소열 $(\mathrm{kJ} / \mathrm{mol})$ 이고, $\mathrm{n}$ 은 기질의 양 (mol)이다. 이전 연구를 보면 acetate의 연소열을 계산한 문헌 이 있다. ${ }^{130,131)}$ 이 문헌의 계산값을 보면 $-874.3 \mathrm{~kJ} / \mathrm{mol}$ 이며 이 값이 실제 미생물 전기화학 시스템에서 가장 정확한 값이다. 그리하여 acetate를 사용하는 경우 기질의 연소열을 -874.3 $\mathrm{kJ} / \mathrm{mol}$ 을 사용하는 것을 추천한다. 기질의 연소열은 문헌마다 다른 값을 사용하거나 표기를 하지 않는다. ${ }^{97,132-135)}$ 그리하여 $\mathrm{MFC}$ 의 정확한 비교 분석을 위해서는 동일한 값의 연소열을 사용하거나 사용한 값을 표기해야 한다. 서로 다른 연소열을 사용한 것을 $-874.3 \mathrm{~kJ} / \mathrm{mol}$ 로 치환하여 계산한 결과는 Table 6에 나와 있다. 기질의 양은 MFC에서 소모된 기질의 양을 의 미하며 이를 식에 연관시켜서 다시 표현하면 다음과 같다. ${ }^{122)}$

$$
\mathrm{EE}=\frac{\int_{0}^{\mathrm{t}} \mathrm{VIdt}}{\Delta \mathrm{Hv}_{\mathrm{an}} \Delta \mathrm{COD} / 8}
$$

또한, 에너지 회수(ER, energy recovery, $\mathrm{kWh} / \mathrm{kg}-\mathrm{COD})$ 은 스 케일 업을 진행한 $\mathrm{MFC}$ 를 평가할 때 사용된다. 이 에너지 회수 는 제거한 $\mathrm{COD}$ 당 생산한 전력이며, 계산식은 다음과 같다. ${ }^{136)}$

$$
\mathrm{ER}=\frac{\mathrm{P}}{\mathrm{Q} \times \triangle \mathrm{COD}}
$$

여기서 $\mathrm{P}$ 는 전력 $(\mathrm{W})$ 이며, $\mathrm{Q}$ 는 유량 $(\mathrm{L} / \mathrm{h}), \triangle \mathrm{COD}$ 는 분해된 $\mathrm{COD}$ 의 농도이다.

$\mathrm{MFC}$ 를 운전할 때 기준전극을 사용하여 운전하는데 이때 주로 $\mathrm{Ag} / \mathrm{AgCl}$ 전극을 사용한다. $\mathrm{Ag} / \mathrm{AgCl}$ 전극은 standard hydrogen electrode (SHE)값으로 변환이 가능하며 관계식은 다음과 같다. ${ }^{137,138)}$ 


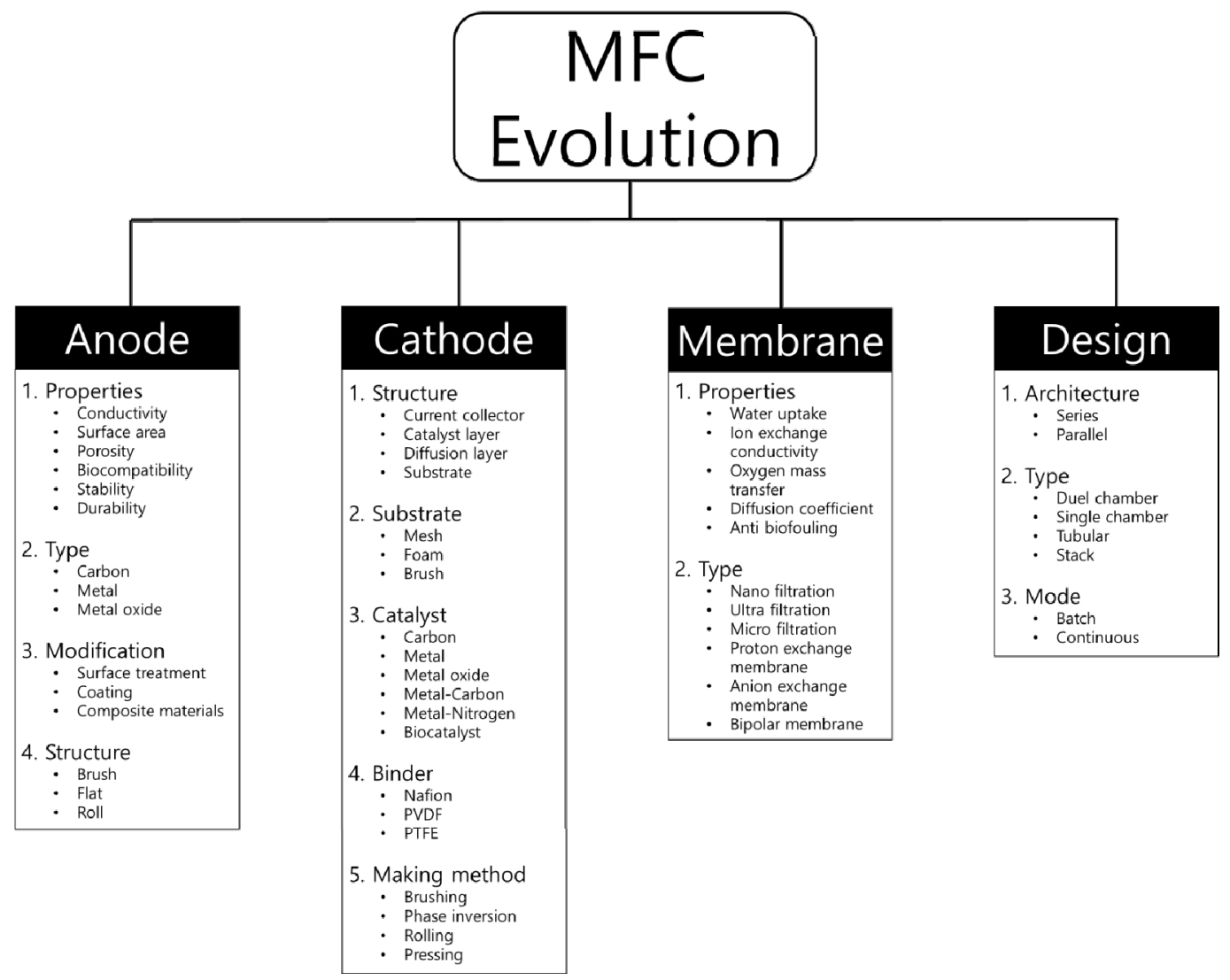

Fig. 4. Schematic diagram of the microbial fuel cell in each component for research.

$$
\mathrm{E}=\mathrm{E}^{0, \mathrm{Ag} / \mathrm{AgCl}}-\frac{\mathrm{RT}}{\mathrm{F}} \ln \mathrm{a}_{\mathrm{Cl}^{-}}
$$

$\mathrm{E}$ 는 $\mathrm{SHE}$ 값 $(\mathrm{mV}), \mathrm{E}^{(0, \mathrm{Ag} / \mathrm{AgCl})}$ 는 $\mathrm{Ag} / \mathrm{AgCl}$ 전극의 표준 전 위, $\ln a_{\mathrm{Cl}^{-}}$는 은 이온의 활성도, $\mathrm{R}$ 은 기체상수 $(8.314 \mathrm{~J} / \mathrm{K} \cdot$ $\mathrm{mol}), \mathrm{T}$ 는 온도 $(\mathrm{K}), \mathrm{F}$ 는 패러데이 상수 $\left(9.64853 \times 10^{4} \mathrm{C} / \mathrm{mol}\right)$ 이다. 이때 기준전극 내부용액의 종류와 농도에 따라 계산값 이 은 이온의 활성도가 달라진다. 여기서 $\mathrm{E}^{0, \mathrm{Ag} / \mathrm{AgCl}}$ 는 다음과 같이 계산한다.

$$
\begin{aligned}
& \mathrm{E}^{0, \mathrm{Ag} / \mathrm{AgCl}}= \\
& \quad-0.111658+0.011134 \mathrm{~T}-0.001757268 \mathrm{~T} \ln \mathrm{T}
\end{aligned}
$$

식. 13 과 14 을 합치면 다음과 같이 표현된다.

$$
\begin{aligned}
\mathrm{E}= & \\
& -0.111658+0.011134 \mathrm{~T}-0.001757268 \mathrm{~T} \ln \mathrm{T}-\frac{\mathrm{RT}}{\mathrm{F}} \ln \mathrm{a}_{\mathrm{Cl}^{-}}
\end{aligned}
$$

이 식을 기반으로 $\mathrm{Ag} / \mathrm{AgCl}$ 전극과 $\mathrm{SHE}$ 의 차이를 계산하면 다음과 같다. 계산에서 사용한 전극은 $\mathrm{MFC}$ 에서 많이 사용하 는 $3 \mathrm{M} \mathrm{KCl}$ 과 $\mathrm{NaCl}$ 을 기준으로 한다. 결과값은 $\mathrm{KCl}$ 은 +210 $\mathrm{mV}$ vs. $\mathrm{SHE}, \mathrm{NaCl}$ 은 $+209 \mathrm{mV}$ vs. $\mathrm{SHE}$ 로 계산된다 $\left(25^{\circ} \mathrm{C}\right.$, $1 \mathrm{~atm}$ 기준). 이를 기반으로 $30^{\circ} \mathrm{C}$ 기준으로써 계산을 하면 $\mathrm{KCl}$ 은 $207 \mathrm{mV}$ vs. $\mathrm{SHE}, \mathrm{NaCl}$ 은 $+206 \mathrm{mV}$ vs. SHE로 $3 \mathrm{mV}$ 의
차이가 생긴다.

\section{Lab scale MFC}

$\mathrm{MFC}$ 의 초창기 연구는 전극이나 반응기가 아닌 미생물의 연구를 중점적으로 진행했다. 2002년 CV와 연료 전지를 사용 하여 철 환원 박테리아인 Shewanella putrefaciens에서 전극으 로 직접 전자가 이동하는 것을 확인했으며, 이는 전자의 이동 에 중간 매개체가 없어도 전자를 전극으로 전달할 수 있는 것을 증명했다. ${ }^{139)}$ 이후 2003 년 중간 매개체가 없는 $\mathrm{MFC}$ 의 성능을 최적화하기 위해 여러 조건에서 실험을 진행했고, 최 적의 $\mathrm{pH}$ 는 7 외부 저항은 $500 \Omega$ 보다 낮으면 양성자 전달 및 용존 산소 공급을 제한하여 성능이 감소한 것을 밝혔다. ${ }^{140)}$ 이 시기의 다른 연구를 보면 하수슬러지를 생체촉매로 하고 $\mathrm{Mn}_{4}{ }^{+}$흑연 음극과 $\mathrm{Fe}_{3}{ }^{+}$흑연 양극을 사용하여 $1750 \mathrm{~mA} / \mathrm{m}^{2}$ 의 최대 전류 밀도와 $788 \mathrm{~mW} / \mathrm{m}^{2}$ 최대 전력 밀도를 달성했다. ${ }^{141)}$ 이러한 결과는 미생물 연료 전지에 의해 전기를 충분히 생산 할 수 있음을 증명했다.

이후 2004년부터 연구는 전극, 반응기와 같은 미생물이 아 닌 연구가 중점적으로 진행되기 시작했다. 2004년의 연구 중 일실형과 이실형 반응기를 통해 가정 폐수를 처리함과 동시에 전기를 생산하는 것을 증명하는 연구가 있다. 이 연구에서 음 
Table 7. Comparison of maximum power density in various MFC.

\begin{tabular}{|c|c|c|c|c|c|c|}
\hline Number & Anode & Cathode & Medium & $\begin{array}{l}\text { Chamber and volume } \\
(\mathrm{mL})\end{array}$ & $\begin{array}{l}\text { Power density } \\
\left(\mathrm{mW} / \mathrm{m}^{2}\right)\end{array}$ & Ref \\
\hline 1 & $\mathrm{TiO}_{2} / \mathrm{SSM}$ & Carbon felt & $\begin{array}{c}\text { A: M9 } \\
\text { C: } 20 \mathrm{mM} \text { PFS }\end{array}$ & $\begin{array}{l}\text { Two } \\
\text { A: } 50 \\
\text { C: } 50\end{array}$ & 2870 & 39) \\
\hline 2 & Coffee AC/Carbon cloth & AC/Carbon cloth & LB medium & $\begin{array}{l}\text { Single } \\
40\end{array}$ & 3927 & 253) \\
\hline 3 & $\mathrm{MnO}_{2} /$ Carbon felt & Carbon brush & $\begin{array}{l}\text { A: } 50 \mathrm{mM} \text { PBS } \\
\text { C: } 10 \mathrm{mM} \text { PFS }\end{array}$ & $\begin{array}{l}\text { Two } \\
\text { A: } 28 \\
\text { C: } 21\end{array}$ & 3580 & 256) \\
\hline 4 & GOA/Graphite felt brush & Graphite felt & $\begin{array}{l}\text { A: LB medium } \\
+100 \mathrm{mM} \text { PBS } \\
\text { C: } 100 \mathrm{mM} \text { PBS } \\
+50 \mathrm{mM} \text { PFS }\end{array}$ & $\begin{array}{l}\text { Two } \\
\text { A: } 75 \\
\text { C: } 75\end{array}$ & 2520 & 266) \\
\hline 5 & Carbon brush & $\mathrm{rGO}, \mathrm{AC}, \mathrm{CB} / \mathrm{SSM}$ & $50 \mathrm{mM}$ PBS & $\begin{array}{c}\text { Single } \\
28\end{array}$ & 2642 & 120) \\
\hline 6 & Carbon felt & $\mathrm{N}$-doped Carbon felt & $50 \mathrm{mM}$ PFS & $\begin{array}{l}\text { Two } \\
\text { A: } 80 \\
\text { C: } 70\end{array}$ & 4990 & 154) \\
\hline 7 & Carbon felt & $\mathrm{AC}, \mathrm{CB} / \mathrm{SSM}$ & $50 \mathrm{mM}$ PBS & $\begin{array}{c}\text { Single } \\
28\end{array}$ & 2311 & 313) \\
\hline 8 & Carbon brush & ZIF-67,AC/SSM & $50 \mathrm{mM}$ PBS & $\begin{array}{l}\text { Single } \\
28\end{array}$ & 4203 & 93) \\
\hline 9 & Carbon paper & NiCoNC/Carbon cloth & $130 \mathrm{mM}$ PBS & $\begin{array}{c}\text { Single } \\
100\end{array}$ & 4335 & 153) \\
\hline
\end{tabular}

SSM = Stainless steel mesh; $A C=$ Activated carbon; $G O A=$ Graphene oxide aerogel; $r G O=$ Reduced graphene oxide; $C B=C$ arbon black; $A=$ anode chamber; $C$ = cathode chamber; $L B=$ luria-bertani; $P B S=$ Phosphate buffered saline; PFS = Potassium ferricyanide solution.

극은 탄소 종이, 양극은 탄소 천을 사용했으며, 이실형에서 사용한 이온막은 PEM을 사용했다. 실험 결과는 이실형에서 $262 \mathrm{~mW} / \mathrm{m}^{2}$, 일실형에서 $494 \mathrm{~mW} / \mathrm{m}^{2}$ 의 최대 전력 밀도 및 이실형에서 $45-55 \%$ 일실형에서 $9-12 \%$ 의 쿨롱 효율을 생산했 다. 이는 이온막을 사용하지 않고 산소를 직접 탄소 양극으로 전달하는 시스템이 비용 효율적인 접근 방식에서 필요할 것이 라고 했다. ${ }^{142}$ 2005년 상향류 $\mathrm{MFC}$ 가 개발과 일실형 MFC의 전극 간격 및 구성, 온도, 이온 강도(ionic strength)에 따른 성 능을 연구했다. ${ }^{143,144)}$ 이러한 연구는 MFC의 다양한 연구가 시작됐다는 것을 보여주었다. 2006년의 대표적인 연구는 확 산층을 촉매층과 분리한 양극, 양극에서 바인더로 주로 사용 하던 나피온이 아닌 PTFE의 새로운 발견, 미생물 양극의 개 발, 새로운 디자인인 스택 형태의 개발 등이 있었다. $52,66,145,140$ 2007년 이전 MFC에서 주로 사용하는 음극은 탄소 종이, 탄소 천과 같은 평평한 형태를 사용했지만, 2007년 흑연 과립을 사 용한 음극을 관(tubular) 형태의 반응기와 접목시켜 새로운 시 스템 개발과 현재 가장 많이 사용하는 브러쉬 형태의 음극이 개발됐다. ${ }^{147,148)}$ 브러쉬 음극을 사용한 연구에서 $2400 \mathrm{~mW} / \mathrm{m}^{2}$ 의 최대 전력 밀도를 생산했으며, 이후 양극의 연구뿐만 아니 라 음극의 개질, 새로운 형태의 음극 등 많은 음극의 연구가 시작됐다. ${ }^{149,150)}$

$\mathrm{MFC}$ 의 전력 밀도를 향상시키기 위해 많은 연구가 진행됐

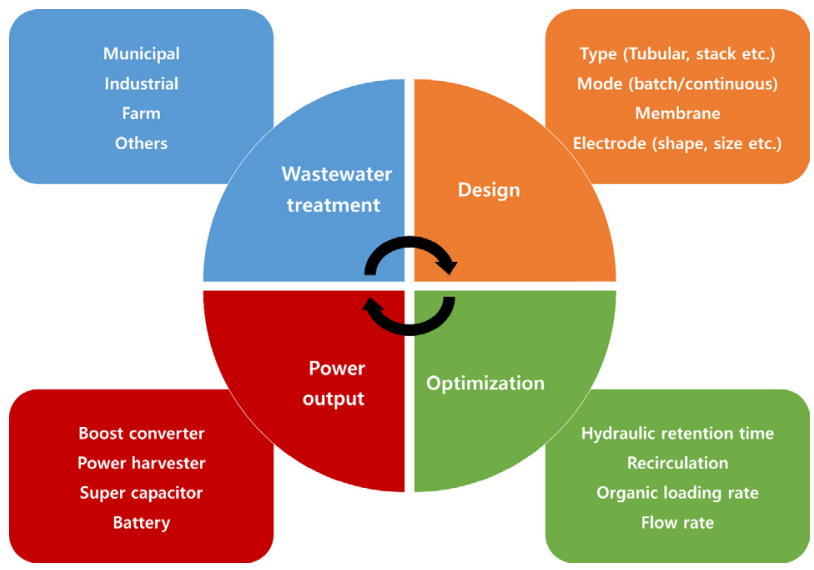

Fig. 5. Schematic diagram of research advancement in MFC scale-up.

다. 1999년 음극의 표면적 기반으로 $0.001 \mathrm{~mW} / \mathrm{m}^{2}$ 에서 0.01 $\mathrm{mW} / \mathrm{m}^{2}$ 로 증가했으며, 2003년 $\mathrm{Mn}_{4}{ }^{+}$흑연 음극과 $\mathrm{Fe}_{3}{ }^{+}$흑연 양극을 사용하여 $788 \mathrm{~mW} / \mathrm{m}^{2}$ 로 증가했다. ${ }^{141,151)}$ 2007년에 일 실형 반응기에서 음극과 양극이 붙어있는 형태의 전극 2 개와 $0.2 \mathrm{M}$ 의 bicarbonate buffer를 사용하여 $2770 \mathrm{~mW} / \mathrm{m}^{2}$ 의 최대 전력 밀도를 달성했다. ${ }^{152)}$ 이후 전력 밀도는 꾸준히 향상하여 최근 $4000 \mathrm{~mW} / \mathrm{m}^{2}$ 이상의 전력 밀도를 달성했다. 첫 번째로 브러쉬 음극, 활성탄과 ZIF-67을 결합하여 제작한 양극, 50 
Table 8. Recent scale-up studies on microbial fuel cell

\begin{tabular}{|c|c|c|c|c|c|c|}
\hline $\begin{array}{l}\text { Volume } \\
\text { (L) }\end{array}$ & Operation mode & Substrate & $\begin{array}{l}\text { Hydraulic retention } \\
\text { time }\end{array}$ & $\begin{array}{l}\text { COD removal } \\
(\%)\end{array}$ & Power density & Ref. \\
\hline 1 & Continuous & Synthetic & $28.4 \mathrm{~h}$ & 43 & $0.13 \mathrm{~W} / \mathrm{m}^{2}$ & 314) \\
\hline 1.5 & Continuous & Swine WW & $\begin{array}{l}1.21 \mathrm{~d} \\
4.84 \mathrm{~d}\end{array}$ & 77 & $175 \mathrm{~W} / \mathrm{m}^{2}$ & 184) \\
\hline 1.5 & Batch & Sludge, Fed synthetic & $91 \mathrm{~h}$ & 88 & $0.133 \mathrm{~W} / \mathrm{m}^{2}$ & 315) \\
\hline 1.5 & Continuous & Sludge, Fed synthetic & $15.5 \mathrm{~h}$ & NA & $0.108 \mathrm{~W} / \mathrm{m}^{2}$ & 315) \\
\hline 1.8 & Continuous & Sludge & $14 d$ & $<60$ & $3.2 \mathrm{~W} / \mathrm{m}^{3}$ & 165) \\
\hline 2 & Continuous & Primary effluent & $11.1 \mathrm{~h}$ & $<53$ & $0.37 \mathrm{~W} / \mathrm{m}^{3}$ & 316) \\
\hline 2.5 & Batch & Manure slurry & NA & NA & $0.03 \mathrm{~W} / \mathrm{m}^{2}$ & 194) \\
\hline 2.7 & Batch & Landfill leachate & $4 d$ & 79 & NA & 317) \\
\hline 2.7 & Continuous & Landfill leachate & $4.68 d$ & 31 & $0.0018 \mathrm{~W} / \mathrm{m}^{2}$ & 317) \\
\hline 3.5 & Continuous & Synthetic & NA & $<80$ & $3.32 \mathrm{~W} / \mathrm{m}^{3}$ & 318) \\
\hline 4 & Continuous & Primary effluent & $11 \mathrm{~h}$ & $>90$ & NA & 319) \\
\hline 5 & Continuous & Synthetic & $2.15 \mathrm{~min}$ & NA & $2.0 \mathrm{~W} / \mathrm{m}^{2}$ & 320) \\
\hline 7.5 & Continuous & Synthetic & $6.2 \mathrm{~h}$ & $\sim 97$ & $2-10 \mathrm{~W} / \mathrm{m}^{3}$ & 321) \\
\hline
\end{tabular}

$\mathrm{mM} \mathrm{PBS}$ 를 사용하여 $4203 \mathrm{~mW} / \mathrm{m}^{2}$ 을 달성했으며 이는 50 $\mathrm{mM}$ PBS 기준으로 현재 세계에서 가장 높은 수치이다. ${ }^{93)}$ 두 번째로 탄소 천의 음극, $\mathrm{Ni} / \mathrm{CoNC}$ 의 촉매를 사용한 양극, 130 $\mathrm{mM}$ PBS를 사용하여 $4335 \mathrm{~mW} / \mathrm{m}^{2}$ 을 달성했다. ${ }^{153)}$ 마지막으 로 탄소 펠트의 음극, 옥수수대를 기반으로 제작한 N-도핑 탄 소 펠트 양극, $50 \mathrm{mM}$ PFS (potassium ferricyanide solution)을 사용하여 $4990 \mathrm{~mW} / \mathrm{m}^{2}$ 을 달성했다. ${ }^{154)}$

\section{5. 스케일 업 MFC}

스케일 업은 크기를 키우는 것 또는 규모를 확대하는 것을 의미한다. 즉, 스케일 업 $\mathrm{MFC}$ 는 실제 실용화를 위해 반응기 의 크기 및 규모를 키우는 것이다. 대부분의 MFC 연구는 실 험실 규모에서 수행됐지만 실제 전기 장치에 전력을 공급하는 데 필요한 전력 수준을 달성하려면 스케일 업을 하는 것이 불가피하다 ${ }^{15)}$. 또한, $\mathrm{MFC}$ 를 하폐수처리장과 같은 실제 응용 분야에 적합하게 만들려면 스케일 업을 하여 높은 전력 밀도 를 달성하는 것이 중요하다.

$\mathrm{MFC}$ 스케일 업은 크게 일실형, 이실형, 플레이트(plate), 관(tubular) 및 스택(stack) 형태의 반응기로 구분할 수 있으며, 이 중 주로 관과 스택 형태로 스케일 업을 진행한다. ${ }^{155)}$ 하지 만, MFC 스케일 업은 규모가 커지면 내부 저항의 증가, 전극 간의 거리의 변경, $\mathrm{pH}$, 유량, 온도와 같은 운전조건 등에 의해 서 성능이 감소한다. ${ }^{29,119,122,156-159)}$ 예를 들어 $250 \mathrm{~L}$ 로 규모로 스케일 업된 $\mathrm{MFC}$ 는 $0.47 \mathrm{~W} / \mathrm{m}^{3}$ 의 최대 전력 밀도를 생산했 다. ${ }^{160)}$ 이는 크기에 비례하여 높은 전력 밀도를 생산하지 않고 상대적으로 낮은 전력 밀도를 생산했다. 이는 반응기가 커짐 에 따라 음극, 양극, 이온막 등 구성 요소의 내부 저항이 증가 했기 때문이다. 이러한 MFC 스케일 업의 성능 감소를 밝히고
최적화를 위해 많은 연구가 진행 중이다. 이 외에도 내부 저항 과 반응기 부피를 곱한 부피 기반 저항률의 관점을 연구한 사례가 있으며, 결과는 반응기 부피가 증가하면 부피 기반 저 항이 증가하는 것을 확인했다. ${ }^{158)}$ 또한 $\mathrm{MFC}$ 의 전극의 표면적 과 생성된 전력 사이의 관계를 정량화한 연구는, 최대 전력 밀도가 음극의 표면적의 로그에 비례하는 것을 밝혔다. ${ }^{157)}$

최근 음극과 양극의 거리와 방향에 따라 MFC 성능과 내부 저항에 상당한 영향을 미치는 것을 확인한 연구가 있다. ${ }^{97)}$ 결 과는 음극의 방향을 수직에서 수평으로 변경하면 최대 전력 밀도가 $20 \%$ 증가, 음극의 저항은 $60 \%$ 감소, 내부 저항은 $49 \%$ 가 감소하는 것을 확인했다. 또한 음극의 전류 포집체 중심과 탄소 섬유 중심을 brush 형태의 음극을 사용하는 MFC의 전기 화학을 설명하는데 통계적으로 중요한 기준점으로 발견했다. 그리고 동일한 크기를 가진 brush 형태의 음극을 사용할 때, 음극의 수와 구성이 MFC 성능 및 전기화학에 미치는 영향을 확인하고, $\mathrm{MFC}$ 성능 향상을 위한 음극의 위치와 삽입 방법을 제안한 연구도 있다. ${ }^{121)}$ 마지막으로 MFC 스케일 업을 진행할 때 전력 생산에 영향을 미치는 결정적인 요인은 부피가 커짐 에 따라 음극과 양극의 표면적의 증가로 제시했다. ${ }^{161)}$ 즉, 전 극의 표면적이 충분히 증가하면 전력 생산과 유기물 이용률이 극대화되어 더 높은 성능을 달성할 수 있다. 위 연구의 결과들 을 종합하면 전극의 간격, 면적, 구성, 부피 등을 고려하고 최 적화하면 스케일 업한 $\mathrm{MFC}$ 의 성능을 증가시킬 수 있다.

\section{1. 실험실 규모}

실험실 규모의 $\mathrm{MFC}$ 는 $1.5 \mu \mathrm{L}$ 에서 $\mathrm{L}$ 단위까지 여러 가지 규모의 반응기로 연구됐다. ${ }^{162-166)}$ 이중 실험실 규모로 스케일 업한 반응기는 $1 \mathrm{~L}$ 이상의 규모로 간주할 수 있다. 이러한 규모의 반응기는 Table 8와 같이 주로 오랜 시간 동안 운전하 
거나 연속흐름식 형태로 운전된다. ${ }^{168-170)}$

MFC 스케일 업에서 중요한 부분인 전극의 연구는 많이 진 행되고 있다. 예시로 가정용 폐수를 사용하여 여러 가지 부피 와 음극 양극의 크기와 표면적에 따라 성능을 평가한 연구가 있다. ${ }^{167)}$ 이 연구는 $250 \mathrm{~mL}, 1 \mathrm{~L}, 1.6 \mathrm{~L}$ 로 총 3 개의 반응기를 구성했다. $250 \mathrm{~mL}$ 와 $1 \mathrm{~L}$ 반응기는 사각형 형태의 통과 원통 형 형태의 플라스틱 통을 사용하여 반응기를 제작했으며, 1.6 $\mathrm{L}$ 반응기는 플렉시글라스(plexiglas)를 사용하여 제작했다. 사 용한 음극은 brush 형태로 $250 \mathrm{~mL}$ 에서 직경 $5 \mathrm{~cm}$, 길이 7 $\mathrm{cm}$ 를 사용했으며, $1 \mathrm{~L}$ 는 직경 $5 \mathrm{~cm}$, 길이 $14 \mathrm{~cm}$, 마지막으로 $1.6 \mathrm{~L}$ 는 $250 \mathrm{~mL}$ 에서 사용한 음극과 동일한 크기의 음극을 총 4 개 사용했다. 양극의 표면적은 $250 \mathrm{~mL}$ 에서 $24,48,72$, $96 \mathrm{~cm}^{2}$ 까지 크기를 점점 늘려가며 사용했으며, $1 \mathrm{~L}$ 는 132 $\mathrm{cm}^{2}, 1.6 \mathrm{~L}$ 는 $290 \mathrm{~cm}^{2}$ 를 2 개 사용했다. 각 규모별 결과는 1.6 $\mathrm{L}$ 에서 $6.8 \mathrm{~W} / \mathrm{m}^{3}, 1 \mathrm{~L}$ 에서 $4.3 \mathrm{~W} / \mathrm{m}^{3}$ 의 최대 전력 밀도를 생산 했다. 또한 $250 \mathrm{~mL}$ 에서 양극의 표면적이 $96 \mathrm{~cm}^{2}$ 인 경우에 최대 전력 밀도 $78 \mathrm{~W} / \mathrm{m}^{3}$ 을 생산했다. 다른 예시로 $\mathrm{MFC}$ 에 여러 가지 탄소 과립을 첨가하여 미생물의 성장과 음극의 유 효 면적을 증가시킨 연구한 사례가 있다. ${ }^{171,172)}$ 탄소 과립이 첨가되면 전하 용량(charge storage)이 증가하여 $\mathrm{MFC}$ 의 최대 전력 밀도가 증가하고 내부 저항이 감소했다. 하지만 너무 많 은 탄소 과립은 오히려 쿨롱 효율이 낮아지고 미생물의 다양 성이 낮아졌다. 이러한 연구들은 $\mathrm{MFC}$ 의 내부 구성요소인 음 극, 양극의 면적, 크기에 따라 성능을 연구했으며, 이를 최적 화하면 스케일 업에 비례하여 성능을 증가시킬 수 있는 방법 중 하나로 시사되고 있다.

$\mathrm{MFC}$ 스케일 업의 연구에서 전극뿐만 아니라 운전조건의 연구도 성능에 많은 영향을 미치는 것으로 밝혀졌다. 회분식 으로 $1 \mathrm{~L}$ 규모의 반응기를 낙농 폐수를 사용하여 MFC 여러 실험 조건에 따라 성능을 평가한 연구를 보면 반응기는 양성 자 교환막(PEM)을 사용하여 음극부와 양극부로 구분하여 1 $\mathrm{L}$ 규모의 이실형 반응기로 제작했으며, 음극은 brush 형태를 사용했고, 양극은 탄소 천(carbon cloth)에 platinum black을 코팅하여 사용했다. ${ }^{173)}$ 실험 조건은 운전시간, 음극의 면적, 이온막의 두께, 이온막의 면적 등을 설정했다. 결과는 음극 면적 $61 \mathrm{~cm}^{2}, 48$ 시간의 운전시간, 효모 추출물 $50 \mathrm{mg} / \mathrm{L}$ 일 때, 최대 전력 밀도 $5.04 \mathrm{~mW} / \mathrm{m}^{2}$ 을 생산했다.

운전조건 중 연속흐름식에서 공기의 흐름과 물이 흐르는 방 향을 연구한 문헌이 있다. ${ }^{153,174,175)} \mathrm{MFC}$ 의 양극부에 스페이서 를 부착하면 공기의 흐름이 원활하게 흐르게 하고 양극 표면 의 막힘을 최소화하여 $32 \mathrm{~W} / \mathrm{m}^{3}$ 의 최대 전력 밀도를 달성 및 HRT 8 시간에서 COD 제거율 $57 \%$ 를 달성했다. 물이 흐르는 방향에 관한 연구는 $85 \mathrm{~L}$ 의 규모로 진행을 했다. 물의 방향은 대각선과 수평 방향 2 가지와 추가적으로 HRT 22분과 77 분에 따른 성능을 비교 분석했다. 결과는 대각선 방향 HRT 22분은 $0.118 \mathrm{~W} / \mathrm{m}^{2}, 77$ 분은 $0.106 \mathrm{~W} / \mathrm{m}^{2}$, 수평방향 HRT 22분은 0.109
$\mathrm{W} / \mathrm{m}^{2}, 77$ 분은 $0.100 \mathrm{~W} / \mathrm{m}^{2}$ 을 나타냈으며, 대각선 방향 HRT 22 분이 $0.118 \mathrm{~W} / \mathrm{m}^{2}$ 의 최대 전력 밀도로 가장 높은 성능을 달 성했다. 이 결과는 수평방향 HRT 77분과 비교하여 최대 전력 밀도가 약 $18 \%$ 의 차이를 보였으며, 이러한 이유는 음극의 과 전압의 감소 때문이었다. 이 연구들은 스케일 업에 영향을 미 치는 여러 조건들을 밝혔다. $\mathrm{MFC}$ 스케일 업에서 운전조건은 중요한 요소임을 밝혔으며, 운전조건을 최적화하면 성능 향상 에 긍정적인 영향을 미칠 수 있음을 입증했다.

위 연구들은 스케일 업을 할 경우 성능에 영향을 미칠 수 있는 각 조건들을 연구했다. $\mathrm{MFC}$ 를 하폐수처리장과 같은 실 제 응용 분야에 접목하기 위하여 처리를 진행함과 동시에 에 너지를 생산 및 회수하는 연구도 많이 진행 중에 있다. ${ }^{176-178)}$ 최근에는 MFC 양극에서 금속 촉매 양극을 사용하지 않고 미 생물 양극을 사용한 연구도 활발하게 진행 중이다. 이러한 연 구 중 $1.84 \mathrm{~L}$ 규모에서 ANAMMOX 첫 단계에 접목하여 탈질 과 전력 생산을 동시에 달성한 연구가 있다. ${ }^{179)}$ 반응기는 각각 2 개의 브러시 형태 음극과 양극을 사용했으며, 이를 병렬로 연결했다. 음극부와 양극부는 이온막을 사용하여 구분했는데 이때 사용한 이온막은 미생물 이온막을 사했였다. 탈질을 위 해 초기 유입수의 총 질소 농도를 $150,300,450,600 \mathrm{mg} / \mathrm{L}$ 로 설정했다. 최대 전력 생산은 총 질소 농도가 $150 \mathrm{mg} / \mathrm{L}$ 에서 $3.4 \mathrm{~W} / \mathrm{m}^{3}$ 을 달성했으며, 총 질소 농도가 $150 \mathrm{mg} / \mathrm{L}$ 보다 높아 지면 오히려 전력 밀도가 떨어졌다. $\mathrm{NH}_{4}{ }^{+}-\mathrm{N}$ 제거는 총 질소 농도가 $50 \mathrm{mg} / \mathrm{L}$ 일 때 최대 $98 \%$ 까지 달성했다. 이는 미생물 양극을 사용한 $\mathrm{MFC}$ 는 $\mathrm{ANAMMOX}$ 공정의 첫 단계로 적합하 는 것을 입증했다.

위의 연구 외에 고강도 축산 폐수를 이용하여 $4 \mathrm{~L}$ 규모에서 지속적으로 처리함과 동시에 전력 생산한 연구가 있다. ${ }^{180)}$ 처 리는 2단계 공정으로 진행했으며, 1단계는 연속 교반 방식으로 처리를 진행하고 1 단계 유출수를 2 단계 공정에서 미생물 양극 을 사용하여 2차 처리를 했다. 처리 결과는 COD 제거율 $97.7 \%$, $\mathrm{NH}_{4}{ }^{+}$-N제거율 $85.1 \%$, TN 제거율 $43.8 \%, 2.509 \mathrm{kWh} / \mathrm{m}^{3}$ 의 순 에너지 생산을 달성했다. 또한, 미생물 양극과 이온막을 사용 하여 $10 \mathrm{~L}$ 규모에서 미생물 이온막의 재료와 개수에 따라 성 능을 평가한 연구도 있다. ${ }^{181)}$ 결과는 $\mathrm{COD}$ 제거율 $86 \%$, 최대 전력 밀도 $67.5 \mathrm{~mW} / \mathrm{m}^{2}$ 을 달성했다. 성능은 미생물 양극과 더 높은 투과성을 가진 미생물 이온막에 의해서 제한됐으며, 미생물 이온막 투과성은 미생물 양극과 이온막의 미생물 군집 구조에도 영향을 미친 것을 확인했다.

\section{2. 스택 반응기}

$\mathrm{MFC}$ 는 현재 실험실 수준의 분석 및 평가 단계에 있지만 최근 몇 년 동안 $\mathrm{MFC}$ 를 실제 구현에 통합하기 위해 새롭고 독창적인 디자인이 개발됐다. 그중 전극 간격, 면적 및 방향 등의 문제를 해결하기 위해 스택 형태의 연구가 진행되고 있 다. 스택 $\mathrm{MFC}$ 는 연속흐름 시스템에서 하나의 유입수를 공유 
하는 여러 장치나 모듈을 연결하여 폐수처리를 목적으로 사용 할 수 있으며, 몇몇 연구에서 스택 형태는 스케일 업에 더 효 과적인 방법일 수 있음을 입증했다. ${ }^{14,84,163,182-187)}$ 스택 형태의 스케일 업 초기 연구 중 하나는 고강도 축산 폐수를 5 개의 모듈로 구성한 스택 MFC에 연결하여 처리했다. ${ }^{184)}$ 이 연구는 기존의 스택 $\mathrm{MFC}$ 의 양극의 단점을 극복하기 위하여 새롭게 설계 및 개발했다. 5 개의 모듈이 직렬 또는 병렬로 연결됐고, $\mathrm{COD}$ 제거율 $77 \%$, 최대 전력 밀도 $176 \mathrm{~W} / \mathrm{m}^{2}$ 을 달성했다. $\mathrm{MFC}$ 스케일 업에서 최적의 구성을 제안하기 위해 연속흐름 에서 운전하는 다양한 $\mathrm{MFC}$ 크기를 연구한 사례가 있다. ${ }^{182)}$ 반응기 구성은 소규모 $\mathrm{MFC}(6.25 \mathrm{~mL})$ 를 각각 5 개 및 10 개씩 연결했고, $25 \mathrm{~mL}$ 규모 반응기 및 $500 \mathrm{~mL}$ 규모 반응기의 성능을 비교했다. 그 결과 음극부 부피 단위당 전력 밀도는 대조군 대비 소규모 5 개를 연결한 반응기에서 $33 \%$, 소규모 10 개를 연결한 반응기에서 $29 \%, 25 \mathrm{~mL}$ 반응기에서 $35 \%, 500$ $\mathrm{mL}$ 반응기에서 $72 \%$ 감소했다. 이러한 결과는 단일 장치의 크기를 늘리는 것보다 여러 소규모 장치를 연결하는 것이 $\mathrm{MFC}$ 스케일 업을 더 잘 수행할 수 있음을 시사한다.

$\mathrm{MFC}$ 장치가 스택으로 연결된 경우 스택 크기 및 구성에 따라 전압, 전류 또는 둘 모두를 높일 수 있다. 각각의 모듈을 추가하거나 제거를 통해 스택의 전체 부피 및 크기를 조정하 여 에너지 요구 사항을 충족할 수 있으므로 매우 유용하다. 그러나 여러 $\mathrm{MFC}$ 를 직렬로 연결하면 전압 반전, 전압 손실 및 각 모듈별 불규칙한 작동 등과 같은 일부 문제가 발생한 다. ${ }^{14,183,188)}$ 직렬 연결한 $\mathrm{MFC}$ 의 예시로 5 개의 모듈을 직렬로 연결하여 8 개월 동안 하수를 처리한 연구가 있다. ${ }^{189)}$ 이는 연 속흐름 방식으로 운전됐으며 COD 제거율과 총 질소 제거 효 율은 처음 1 달 동안 각각 $78 \%, 77 \%$ 였지만, 8 개월 운전 후 처리 효율이 증가하여 각각 $85 \%, 94 \%$ (COD 유출수 농도: $20.7 \pm 2.5 \mathrm{mg} / \mathrm{L}, \mathrm{T}-\mathrm{N}$ 유출수 농도: $1.7 \pm 0.1 \mathrm{mg} / \mathrm{L})$ 를 달성했 다. 이 연구에서 $\mathrm{COD}$ 제거와 질소 제거는 대부분 처음과 두 번째 모듈에서 진행됐으며, 뒤쪽 모듈로 갈수록 유입수의 $\mathrm{COD}$ 와 총 질소가 낮아져서 높은 성능을 보이지 못했다.

구불구불한 형태(serpentine-type)로 총 40 개의 모듈을 연결 하여 스택 $\mathrm{MFC}$ 를 제작한 연구가 있다. ${ }^{185)}$ 이 연구에서 스택 $\mathrm{MFC}$ 는 $10 \mathrm{~L}$ 규모로 제작됐으며 양조장 폐수를 처리했다. 결 과는 개방 회로 전압을 $23 \mathrm{~V}$ 까지 생산했으며, 최대 전력 밀도 는 $4.1 \mathrm{~W} / \mathrm{m}^{3}$ 을 달성했다. 하지만 장시간 운전을 하니 성능이 감소했다. 이는 스택 $\mathrm{MFC}$ 에서 장시간 운전 시 성능이 저하되 는 것은 양극에 의한 것으로 밝혀졌다. ${ }^{185,189)}$ 스택 $\mathrm{MFC}$ 를 장 시간 운전하면 유입수에 존재하는 여러 유기물과 무기물에 의해 양극 표면에 염, 침전물 및 미생물 부착이 되어 양극이 비활성화됐고 이는 성능 저하로 이어졌다. 이러한 성능 저하 를 해결하기 위해 양극에 붙어 있는 염이나 이물질을 물로 세척하면 성능이 회복됐다. 양극 표면에 염이나 침전물이 부 착에 의한 성능 저하는 장기간 운전 시 공통적으로 발생하는
문제이다. ${ }^{14,184,185,189-191)}$ 이를 극복하는 방법 중 하나는 양극에 서 수분이 증발하는 양을 줄이거나 부분적으로 잠긴 양극을 충분히 물에 적셔주는 것이다. ${ }^{178,192-194)}$

스택 $\mathrm{MFC}$ 는 일반적으로 전기적, 수리학적으로 모두 연결 되어 연속흐름 조건에서 운전한다. 하지만, 연결하는 모듈의 수가 증가할수록 모듈간의 연결이 더욱 복잡해지며, 연결한 모듈을 연속흐름 조건으로 연결 및 운전하려면 모듈의 유입 및 유출을 유동적(fluidic)으로 결합해야 한다. ${ }^{122,195)} \mathrm{MFC}$ 의 초창기 연구 중에서 모듈을 전기적, 수리학적 연결과 분리에 따른 성능을 평가한 연구가 있다. ${ }^{14)}$ 이 결과에 따르면 전기적 으로 연결되고 수리학적 분리가 된 상태에서의 성능은 1.3 $\mathrm{W} / \mathrm{m}^{3}$ 으로 둘 다 연결된 상태보다 약 $36 \%$ 더 높은 값을 나타 냈다. 이는 수리학적 분리가 스택 $\mathrm{MFC}$ 에 더 좋은 영향을 미 칠 수 있다는 것을 시사한다. 하지만 수리학적 분리가 된 스택 $\mathrm{MFC}$ 는 기질의 공급 및 배출을 위한 개별적인 재순환이 필요 하며 특히 하수처리장과 같은 곳에서 응용을 하기 위해서는 필수적이다. 이러한 연결 문제를 해결하기 위해 양이온 교환 막을 추가하여 내부적으로 연결된 새로운 형태의 스택 $\mathrm{MFC}$ 가 개발됐다. ${ }^{183)}$ 각 모듈의 성능은 $\mathrm{COD}$ 제거율과 전력 밀도에 중점을 두었으며, 단일 모듈에서 $1 \mathrm{~W} / \mathrm{m}^{3}$ 의 최대 전력 밀도와 $32 \%$ 의 $\mathrm{COD}$ 제거율을 보였지만 2개의 모듈을 연결한 결과 $1.4 \mathrm{~W} / \mathrm{m}^{3}$ 의 최대 전력 밀도와 $54 \%$ 의 $\mathrm{COD}$ 제거율을 달성했다.

\section{3. 파일럿(Pilot) 규모 스케일 업}

파일럿 규모의 반응기를 테스트하는 대표적인 방법은 MFC 기반 시스템을 폐수처리 시설에 접목하는 것이며, 실제 많은 파일 럿 규모의 연구들은 실제 하수처리와 접목하여 진행했다. ${ }^{178,196-200)}$ 하지만 $\mathrm{MFC}$ 의 연구는 파일럿 규모의 연구보다 실험실 규모 로 많이 진행 중에 있으며 파일럿 규모의 연구는 아직 많이 진행되지 않았다. $\mathrm{MFC}$ 에 대한 첫 번째 파일럿 규모 스케일 업은 호주 퀸즐랜드 골드 코스트시에 있는 야탈라에서 진행됐 다. ${ }^{201)}$ 이때 사용한 반응기는 높이가 $3 \mathrm{~m}$, 부피는 $1 \mathrm{~m}^{3}$ 로 총 12 개를 제작했다. 반응기는 관형 반응기로 내부에 탄소 섬유 brush를 음극으로 사용했고, 반응기 외부는 흑연 섬유 brush를 사용한 양극을 설치했다. 유입수는 반응기 내부로 들어가서 튜브를 통해 위로 흐르고 양극으로 이동했다. 이 연구에 관한 내용은 많이 알려져 있지 않다. 현재까지 알려진 바로는 i) 양조장에서 진행을 했으며, ii) 용액의 전도도가 낮고, iii) 전류 생산이 제한됐으며, iv) 음극부의 유출수에 과도한 COD로 인 해 양극에 생물막이 과도하게 축적됐다는 것이다.

최근 파일럿 규모의 연구에서 낮은 농도의 $\mathrm{COD}$ 로 운영될 때에도 안정성을 보여준 도시 폐수 처리장에 막이 없는 $45 \mathrm{~L}$ 스택의 통합을 제시했다. ${ }^{202)}$ 이온막을 사용하여 총 부피 $72 \mathrm{~L}$ 스택 반응기를 사용하여 회분식과 연속흐름식을 연구한 사례 가 있다. ${ }^{203)}$ 결과는 회분식에서는 $51 \mathrm{~W} / \mathrm{m}^{3}$ 의 최대 전력 밀도, $97 \%$ 의 $\mathrm{COD}$ 제거율을 보였고, 연속흐름식에서는 $42 \mathrm{~W} / \mathrm{m}^{3}$ 의 
최대 전력 밀도, $5.2 \mathrm{~kg} \mathrm{COD} / \mathrm{m}^{3} \cdot \mathrm{d}$ 의 $\mathrm{COD}$ 제거율을 달성했 다. 하지만 병렬 회로에서 전류 손실이 발생했다. 이 외에도 총 부피 $90 \mathrm{~L}(18 \mathrm{~L}$ 모듈 5 개)의 양조장 폐수를 활용한 파일 럿 연구에서 직물 기반 분리막을 사용하여 음극과 양극 사이 의 단락을 방지하고 생산된 전기를 펌핑 시스템을 구동하는 데 사용한 연구가 있다. ${ }^{204}$

$\mathrm{MFC}$ 의 실증을 위해 파일럿 규모로 $\mathrm{MFC}$ 를 스케일 업하여 실제 하수처리장과 접목한 사례가 있다. ${ }^{117,196,197,199)}$ 파일럿 규 모로 하수처리장에 접목한 사례 중에서 $1000 \mathrm{~L}$ 스택 $\mathrm{MFC}$ 시스템을 구축하여 도시 폐수를 처리한 연구가 있다. ${ }^{197)}$ 이 연구는 MFC 반응기 안에서 물이 흘러가는 방향을 2 가지 방 식으로 설정하고 2 개의 폐수처리장에서 1년 이상 $\mathrm{COD}$ 농도 에 따른 폐수 처리 능력을 평가했다. 결과는 유출수의 COD 농도는 $50 \mathrm{mg} / \mathrm{L}$ 미만으로 $\mathrm{COD}$ 제거율 $90 \%, 70 \mathrm{~W} / \mathrm{m}^{3}$ 의 최대 전력 밀도, HRT 2시간으로 도시 폐수 $1 \mathrm{~m}^{3}$ 당 $0.033 \mathrm{kWh} / \mathrm{m}^{3}$ 의 에너지 회수를 달성했다. 다른 연구는 $1.5 \mathrm{~m}^{3}$ 규모로 미생 물 음극, 양극 그리고 분리막을 사용하여 여름부터 겨울까지 4 개월 동안 1 차 침전조 방류수를 처리했다. ${ }^{117)}$ 그 결과 HRT 5 시간 기준으로 $\mathrm{COD}(25 \pm 7 \mathrm{mg} / \mathrm{L}), \mathrm{TN}(13 \pm 2 \mathrm{mg} / \mathrm{L})$, $\mathrm{NH}_{4}{ }^{+}-\mathrm{N}(3 \pm 1 \mathrm{mg} / \mathrm{L})$ and $\mathrm{SS}(10 \pm 3 \mathrm{mg} / \mathrm{L})$ 를 처리했으며, 미생물 분리기의 경우 $1 \mathrm{~m}^{3}$ 당 $406 \pm 30 \mathrm{~mW} / \mathrm{m}^{3}$ 의 전력 생산 을 달성했다. 이 외에 미생물 양극과 이온막을 이용하여 1.5 $\mathrm{m}^{3}$ 규모의 스택 $\mathrm{MFC}$ 를 개발 및 성능을 평가한 연구가 있다 199. 반응기는 1 차 침전지, 생물학적 전기화학 처리조, 2 차 침전지로 구분했으며, 원활한 처리를 위하여 생물학적 전기화 학 처리조에 폭기를 했다. 각 반응조의 HRT는 1차 침전지 1시 간, 생물학적 전기화학 처리조 5 시간, 2 차 침전지 0.5 시간으로 설정했다. 유입수의 방향은 48시간마다 주기적으로 변경하여 음극의 성능을 안정화했고, 이는 물의 흐름에 따라 반응기의 균일성을 유지하는데 효과적인 것을 입증했다. 최대 전력 밀 도는 $20 \mathrm{~mW} / \mathrm{m}^{2}$ 이었으며, 에너지 요구량은 일반적인 활성 슬 러지 공정의 $7.3 \%$ 에 불과했다. 이 외에도 최근 64 개의 모듈로 구성하여 $1 \mathrm{~m}^{3}$ 의 규모로 제작한 연구가 있다. ${ }^{196)}$ 유입수는 하 수처리장의 1 차 정화조 유출수를 사용했다. 결과는 최대 $95 \%$ 의 $\mathrm{COD}$ 제거율, 암모니아는 $48 \%$, 유기 미량 오염물질은 $65 \%$ 를 제거했고 약 $12 \%$ 의 에너지 효율로 $0.06 \mathrm{kWh} / \mathrm{m}^{3}$ 의 전력을 생산했다.

파일럿 규모 연구 중 하수처리장이나 양조장과 같은 폐수를 사용한 것이 아닌 실제 화장실에 접목한 연구가 있다. ${ }^{178,198)}$ 이 연구는 화장실 소변기에 $\mathrm{MFC}$ 를 접목하여 실제 화장실의 내부 조명에 필요한 전력을 $\mathrm{MFC}$ 로 생산하여 사용했다. ${ }^{178)}$ 첫 번째 테스트는 2015년 2월부터 5월까지 브리스틀 웨스트잉글 랜드 대학교 Frenchay 캠퍼스에 설치했으며, 두 번째 테스트는 2015년 6월 영국 남서부 Worthy Farm에서 열린 Glastonbury Music Festival에 설치했다. 소변기의 실시간 전기 출력은 온 도와 유속에 따라 사용된 MFC의 수에 비례했다. 캠퍼스 소변
기는 288개의 $\mathrm{MFC}$ 로 구성되어 평균 $75 \mathrm{~mW}$, 최대 $160 \mathrm{~mW}$ 의 전력을 생산했으며, 축제에 설치된 소변기는 432 개의 MFC 로 구성되어 평균 $300 \mathrm{~mW}$, 최대 $400 \mathrm{~mW}$ 의 전력을 생산했다. $\mathrm{COD}$ 제거율은 캠퍼스 소변기의 경우 약 $95 \%$, 축제 소변기의 경우 평균 $30 \%$ 이었다. 이러한 결과는 파일럿 규모의 $\mathrm{MFC}$ 를 화장실에 접목하여 전력 생산과 $\mathrm{COD}$ 제거에 $\mathrm{MFC}$ 를 입증한 첫 번째 시도이다. 이 연구 이후 다시 한 번 Glastonbury Music Festival의 화장실 소변기에 $\mathrm{MFC}$ 를 접목하여 설치했다. ${ }^{198)}$ 반 응기는 총 12 개의 모듈로 이루어진 스택 $\mathrm{MFC}$ 로 구성했다. 이 실험의 결과는 이전 연구에 비하여 COD 제거율은 $37 \%$ 가 향상됐으며, 전력 생산은 약 $30 \%$ 가 증가함에 따라 에너지 회 수는 $0.022 \mathrm{kWh} / \mathrm{m}^{3}$ 에서 $0.346 \mathrm{kWh} / \mathrm{m}^{3}$ 으로 향상됐다. 이 결 과는 MFC 스케일 업의 난제 중 하나인 크기가 커짐에 따라 생산되는 전력이 감소하는 것을 개선했으며, 국내 하수처리장 에서 하수처리에 필요한 전력 사용량 $\left(0.4 \mathrm{kWh} / \mathrm{m}^{3}\right)$ 의 약 $86.5 \%$ 를 MFC를 통해 충당할 수 있다. ${ }^{205,206)}$ 다시 말하면, 스 택형 $\mathrm{MFC}$ 를 통해 향상된 전력 생산은 $\mathrm{MFC}$ 실용화의 궁극적 인 목표인 에너지 공급형 하수처리장이 가까워졌다는 것을 시사한다.

파일럿 규모의 $\mathrm{MFC}$ 는 주로 하수처리장에 접목하여 테스트 하지만 그 외 습지나 식물 뿌리를 이용하여 테스트하는 경우 가 있다. ${ }^{207-211)}$ 습지에 접목한 연구의 예시로 $30 \mathrm{~L}$ 파일럿 규모 로 습지에 접목하여 연구한 사례가 있다. 이 연구의 결과는 $92 \%$ 의 $\mathrm{COD}$ 제거율, $97 \%$ 의 $\mathrm{NH}_{4}{ }^{+}-\mathrm{N}$ 제거, $8 \mathrm{~mW} / \mathrm{m}^{2}$ 의 최대 전력 밀도를 달성했다. ${ }^{207}$ 연구에서 사용한 전극은 1 개의 양 극과 4 개의 양극을 이용했는데, 이때 음극과 양극을 병열로 연결하는 것이 4 개의 음극을 1 개의 외부저항과 연결시켜 양 극과 연결하는 것보다 더 좋다는 것을 밝혔다. 또한, 습지에 접목하여 $\mathrm{MFC}$ 를 테스트할 때, 양극과 공기의 접촉을 꾸준히 유지하는 것이 습지에 접목한 $\mathrm{MFC}$ 의 핵심 요소임을 밝혔다. 식물 뿌리에 접목한 사례는 식물 뿌리 아래 즉, 땅속에 MFC 를 접목해서 $11.67 \mathrm{~mW} / \mathrm{m}^{3}$ 의 최대 전력 밀도를 달성했다. ${ }^{208)}$ 이 연구는 $\mathrm{MFC}$ 를 땅속에 접목하면 $\mathrm{MFC}$ 의 음극이 오염물질 의 산화를 위한 임시 전자 수용체 역할을 해서 오염물질의 처리 성능을 약 $33 \%$ 이상 향상시킬 수 있음을 입증했다. 이러 한 연구 결과는 MFC가 하수처리장뿐만 아니라 더 많은 범위 에 접목할 수 있으며, 탁월한 폐수처리 능력을 가진 것을 알 수 있다.

\section{6. 향후 전망}

폐수는 환경 오염의 주요 원인으로 인식되고 있다. 현재 폐 수처리기술은 악취, 에너지, 슬러지, 비용 등의 많은 단점이 있다. $\mathrm{MFC}$ 는 폐수를 처리함과 동시에 추가적인 공정 없이 에너지를 폐수에서 바로 추출할 수 있고, 이 추출된 에너지는 하수처리 공정으로 다시 사용이 가능하여 하수처리공정에 필 
요한 에너지와 관련된 비용을 줄일 수 있다. 또한, MFC는 활 성 또는 혐기성 처리에 비해 슬러지 생산량이 낮고 이전 연구 에 따르면 $\mathrm{MFC}$ 를 통해 여러 종류의 오염물질을 효과적으로 제거할 수 있다.212-214) 이러한 이점을 제공하는 $\mathrm{MFC}$ 는 환경친 화적인 공정으로 폐수처리 분야에서 혁신적인 기술로 인식되 고 있다.

지난 20여년 동안 MFC의 실용화를 위해 많은 연구가 수행 됐고, 그에 따라 많은 문제가 확인됐다. 가장 중요한 문제는 $\mathrm{MFC}$ 의 비용 효율성이다. 이전 연구에 따르면 $\mathrm{MFC}$ 의 스케일 업에 필요한 비용은 $735-36,000 \$ / \mathrm{m}^{3}$ 이다. ${ }^{197,215)}$ 높은 비용의 문제는 $\mathrm{MFC}$ 의 구성 요소인 전극과 이온막이 주요 원인이었 으며. 양극의 촉매와 이온막의 비용이 전체 비용의 약 $80 \%$ 를 차지한다. ${ }^{216)}$ 대표적으로 양극과 이온막에서 많이 사용하는 촉매인 백금 촉매의 비용은 $150 \$ / \mathrm{g}$ 으로 가격이 매우 높으며, 백금 촉매를 사용하면 비용이 크게 증가하여 스케일 업에 적 합하지 않다. ${ }^{217)}$ 즉, 비용을 줄이기 위해 높은 경제성과 성능 을 가진 전극과 막 개발이 필요하다. 최근 스케일 업에 미생물 을 양극과 이온막에 접목시켜 사용하기 시작했다. ${ }^{117,218)}$ 미생 물 양극과 미생물 이온막은 기존 전극과 이온막의 문제점인 안전성, 내구성, 높은 비용, 막힘 현상, 높은 내부 저항 등을 개선할 수 있다. ${ }^{219,220)}$ 즉, 미생물 양극과 미생물 이온막은 $\mathrm{MFC}$ 스케일 업에 가장 중요한 문제인 비용을 획기적으로 줄 일 수 있고 에너지 생산 및 오염물질 제거를 할 수 있어 향후 실용화에 유망한 방법으로 생각된다.

전극과 이온막의 비용 외에도 펌프, 혼합, 폭기와 같은 전력 소비에 관한 운영 비용도 전체적인 비용에 영향을 미친다.221) 그리하여 수중에 $\mathrm{MFC}$ 를 사용하거나 스택형 모듈을 사용하여 기존 하수처리장에 접목하여 펌프나 폭기에 필요한 에너지 소비를 줄일 수 있어 비용 효율적이고 지속 가능하다. 222) 운영 비용을 줄이기 위한 방법으로 $\mathrm{MFC}$ 의 전력 생산을 높이는 것 도 있다. 즉, 폐수처리와 관련하여 $\mathrm{MFC}$ 에 필요한 에너지를 소비하는 것이 아닌 $\mathrm{MFC}$ 에서 생산한 자체 전력을 이용하여 운영 비용을 낮추는 것이다. 전력 생산을 높이는 방법으로는 전극이나 이온막의 개선도 있지만, 여러 모듈을 사용하는 스 택형 반응기를 사용하는 방법도 있다. 스택형 반응기를 사용 하면, 에너지 손실을 줄일 수 있어 더 높은 전력을 생산하는 것이 입증됐다. ${ }^{223)}$ 하지만 반응기를 스택형으로 구성하면 동 역학적 불균형 및 전압 역전(voltage reversal)이 생기는 문제 가 있다. ${ }^{203,224-225)}$ 스택 $\mathrm{MFC}$ 의 높은 성능을 달성하고 전압 역 전 등을 방지하려면 전극 유형, 모듈 형태, 연결 방법 등을 신중하게 고려하고 선택해야 한다. 이러한 비용은 MFC의 구 성 및 운전 방법 등에 따라 달라지므로 구성 요소의 비용과 운영비용 간의 균형은 전력 생산과 함께 지속 가능한 폐수처 리의 핵심이다.

$\mathrm{MFC}$ 의 실용화를 위해서는 비용뿐만 아니라 운전조건, 장 기적인 내구성, $\mathrm{COD}$ 및 영양염류의 제거도 고려해야 한다.
운전조건은 온도, $\mathrm{pH}$, 유기물 부하율, 전도도, $\mathrm{HRT}$, 기질의 염도, 접종 방법 등이 연구되고 있으나 이러한 연구들은 대부 분 실제 폐수에서 연구되지 않고 특정 기질 및 농도를 사용하 여 연구된다. ${ }^{227-233)}$ 따라서 운전조건에 관한 연구는 MFC 실용 화를 위해 실제 폐수를 기반으로 심도 있게 연구되어야 한다. 또한, 실제 폐수를 이용하여 연구를 진행하면 생물학적 오염, 부식, 막힘 현상을 야기할 수 있어 장기적으로 운전하기 위해 내구성에 관한 연구도 필요하다. ${ }^{234-236)}$ 이러한 연구뿐만 아니 라 MFC의 실용화를 위해서는 높은 유기물 및 영양염류의 제 거를 달성해야 한다. 하지만 실제 폐수는 많은 오염물질이 존 재하여 $\mathrm{MFC}$ 가 모든 물질을 제거할 수는 없으므로 오염물질 의 제거는 기존의 다른 하수처리 공정을 접목하여 전처리와 후처리를 통해 높은 제거율을 달성할 수 있다. ${ }^{237,238)}$

$\mathrm{MFC}$ 는 많은 분야에 적용이 가능하지만, 가장 유망한 응용 분야는 폐수처리 분야이다. $\mathrm{MFC}$ 는 하수처리장에 접목하여 남아있는 유기물을 제거할 수 있고 하수처리장 운영을 위한 에너지를 생산할 수 있다. 이러한 $\mathrm{MFC}$ 는 성능 개선을 위해 많은 연구가 수행됐고, 실제 하수처리장과 접목하는 성과를 보이는 등 MFC 실용화의 가능성을 보여줬다. 현재 MFC 스 케일 업의 연구 추세는 다음과 같다. i) 높은 비용을 줄이기 위한 높은 경제성과 성능을 가진 전극과 막의 개발, ii) 장기간 운전을 위해 오염, 부식 및 막힘에 대한 내성을 가진 재료의 개발, iii) 손실을 최소화하기 위해 여러 개의 모듈을 연결하는 방식인 스택 형태로 스케일 업을 진행한다. 하지만 스케일 업 을 방해하는 여러 가지 장애물은 여전히 존재한다. 주요 장애 물로는 높은 비용, 내부 손실에 따른 낮은 전력 생산, 내구성 및 오염물질의 제거이다. 따라서 높은 비용과 내부 손실을 줄 이기 위해 효율적인 전극과 이온막의 개발과 실제 폐수의 처 리 효율을 증가시키는 것이 중요하다. 지금까지 MFC 스케일 업의 연구 결과를 보면 스택 형태로 구성하는 것이 내부 손실 을 줄여 높은 성능을 달성할 수 있고 단일 반응기의 규모를 키우는 것보다 저렴하며, 높은 오염물질 처리능력을 보여줬 다. 향후 실용화를 위한 스케일 업의 연구 전략을 제안하면 다음과 같다. 첫 번째로 스택 형태의 반응기를 이용, 두 번째 로 내부 저항과 비용을 줄이기 위해 이온막이 없는 반응기 사용, 세 번째로 양극을 내구성과 지속가능성의 궁극적인 촉 매인 미생물 양극의 사용, 마지막으로 처리 효율을 높이기 위해 다른 하수처리 공정을 접목하여 전처리 및 후처리를 통 해 높은 처리 효율 달성이다. 이러한 MFC 기술은 환경, 화학, 에너지, 생물학, 재료 등과 같은 많은 학문이 결합된 연구이 다. 즉, 학자들의 긴밀한 협업이 중요하다. 앞으로 지속적인 연구를 진행하면 MFC 기술의 궁극적인 목표인 에너지 공급 형 하폐수처리장의 실용화가 멀지 않았으며, 지속 가능한 물에너지 연계(water-energy nexus)의 유일한 기술로 우뚝 설 것 이다. 


\section{Acknowledgement}

이 논문은 대한민국 과학기술정보통신부의 재원으로 한국 연구재단 중견연구자지원사업(NRF-2021R1A2C1013989), 전 남대학교 학술연구비(과제번호 2020-3907) 및 2021학년도 대 진대학교 학술연구비의 지원을 받아 수행되었습니다.

\section{References}

1. http://www.worldometers.info/kr/1. Worldmeters.info, Real time world statistics, (Nov 01 2018).

2. Unicef, Progress on household drinking water, sanitation and hygiene, 2000-2020 https://data.unicef.org/resources/progress -on-household-drinking-water-sanitation-and-hygiene-2000-2 020/, (2021).

3. Enerdata, World energy https://yearbook.enerdata.co.kr/totalenergy/world-consumption-statistics.html, (Nov 01 2018).

4. D. R. Lovley, Bug juice: harvesting electricity with microorganisms, Nature Reviews Microbiology, 4(7), 497-508 (2006).

5. B. E. Logan, B. Hamelers, R. Rozendal, U. Schröder, J. Keller, S. Freguia, P. Aelterman, W. Verstraete, K. Rabaey, Microbial fuel cells: methodology and technology, Environmental science \& technology, 40(17), 5181-5192(2006).

6. M. C. Potter, Electrical effects accompanying the decomposition of organic compounds, Proc. R. Soc. Lond. B, 84(571), 260-276(1911).

7. B. Cohen, The bacterial culture as an electrical half-cell, J. Bacteriol, 21(1), 18-19(1931).

8. S. G. A. Flimban, I. M. I. Ismail, T. Kim, S.-E. Oh, Overview of Recent Advancements in the Microbial Fuel Cell from Fundamentals to Applications: Design, Major Elements, and Scalability, Energies, 12(17), 3390(2019).

9. A. Shukla, P. Suresh, B. Sheela, A. Rajendran, Biological fuel cells and their applications, Current science, 87(4), 455-468(2004).

10. B. H. Kim, H. J. Kim, M. S. Hyun, D. H. Park, Direct electrode reaction of Fe (III)-reducing bacterium, Shewanella putrefaciens, Journal of Microbiology and Biotechnology, 9, 127-131(1999).

11. D. R. Bond, D. R. Lovley, Electricity Production by Geobacter sulfurreducens Attached to Electrodes, Applied and Environmental Microbiology, 69(3), 1548(2003).

12. J. Sokhee Philemon, Practical Implementation of Microbial Fuel Cells for Bioelectrochemical Wastewater Treatment, Journal of the Korean Society of Urban Environment, 13(2), 93-100(2013).

13. H. Wang and Z. J. Ren, A comprehensive review of microbial electrochemical systems as a platform technology, Biotechnology advances, 31(8), 1796-1807(2013).

14. L. Zhuang and S. Zhou, Substrate cross-conduction effect on the performance of serially connected microbial fuel cell stack, Electrochemistry Communications, 11(5), 937-940(2009).
15. V. Oliveira, M. Simões, L. Melo, A. Pinto, Overview on the developments of microbial fuel cells, Biochemical engineering journal, 73, 53-64(2013).

16. I. Gajda, J. Greenman, I. A. Ieropoulos, Recent advancements in real-world microbial fuel cell applications, Current Opinion in Electrochemistry, 11, 78-83(2018).

17. Y.-C. Song, D.-S. Kim, J.-H. Woo, K. Yoo, J.-W. Chung, C.-Y. Lee, Modification of Anode Surface with Hydrogel and Multiwall Carbon Nanotube for High Performance of Microbial Fuel Cells, Journal of Korean Society of Environmental Engineers, 34(11), 757-764(2012).

18. Y.-C. Song, J.-H. Woo, K.-S. Yoo, Materials for microbial fuel cell: electrodes, separator and current collector, Journal of Korean Society of Environmental Engineers, 31(9), 693-704(2009).

19. B. E. Logan, Exoelectrogenic bacteria that power microbial fuel cells, Nature Reviews Microbiology, 7(5), 375-381(2009).

20. R. K. Thauer, K. Jungermann, K. Decker, Energy conservation in chemotrophic anaerobic bacteria, Bacteriological reviews, 41(1), 100-180(1977).

21. R. Ma, G. Lin, Y. Zhou, Q. Liu, T. Zhang, G. Shan, M. Yang, J. Wang, A review of oxygen reduction mechanisms for metal-free carbon-based electrocatalysts, npj Computational Materials, 5(1), 1-15(2019).

22. S. Tanisho, N. Kamiya, N. Wakao, Microbial fuel cell using Enterobacter aerogenes, Bioelectrochemistry and Bioenergetics, 21(1), 25-32(1989).

23. X.-Y. Wu, F. Tong, T.-S. Song, X.-Y. Gao, J.-J. Xie, C. C. Zhou, L.-X. Zhang, P. Wei, Effect of zeolite-coated anode on the performance of microbial fuel cells, Journal of Chemical Technology \& Biotechnology, 90(1), 87-92(2015).

24. T. Huggins, H. Wang, J. Kearns, P. Jenkins, Z. J. Ren, Biochar as a sustainable electrode material for electricity production in microbial fuel cells, Bioresource Technology, 157, 114-119(2014).

25. N. Zhu, X. Chen, T. Zhang, P. Wu, P. Li, J. Wu, Improved performance of membrane free single-chamber air-cathode microbial fuel cells with nitric acid and ethylenediamine surface modified activated carbon fiber felt anodes, Bioresource Technology, 102(1), 422-426(2011).

26. C. Santoro, M. Guilizzoni, J. P. Correa Baena, U. Pasaogullari, A. Casalegno, B. Li, S. Babanova, K. Artyushkova, P. Atanassov, The effects of carbon electrode surface properties on bacteria attachment and start up time of microbial fuel cells, Carbon, 67, 128-139(2014).

27. Y.-Y. Yu, C. X. Guo, Y.-C. Yong, C. M. Li, H. Song, Nitrogen doped carbon nanoparticles enhanced extracellular electron transfer for high-performance microbial fuel cells anode, Chemosphere, 140, 26-33(2015).

28. K. Dolch, J. Danzer, T. Kabbeck, B. Bierer, J. Erben, A. H. Förster, J. Maisch, P. Nick, S. Kerzenmacher, J. Gescher, Characterization of microbial current production as a function of microbe-electrode-interaction, Bioresource Technology, 157, 284-292(2014).

29. T. Nam, S. Son, B. Koo, H. V. H. Tran, J. R. Kim, Y. Choi, 
S. P. Jung, Comparative evaluation of performance and electrochemistry of microbial fuel cells with different anode structures and materials, international journal of hydrogen energy, 42(45), 27677-27684(2017).

30. M. Zhou, M. Chi, J. Luo, H. He, T. Jin, An overview of electrode materials in microbial fuel cells, Journal of Power Sources, 196(10), 4427-4435(2011).

31. T. Cai, L. Meng, G. Chen, Y. Xi, N. Jiang, J. Song, S. Zheng, Y. Liu, G. Zhen, M. Huang, Application of advanced anodes in microbial fuel cells for power generation: A review, Chemosphere, 248, 125985(2020).

32. J. M. Sonawane, A. Yadav, P. C. Ghosh, S. B. Adeloju, Recent advances in the development and utilization of modern anode materials for high performance microbial fuel cells, Biosensors and bioelectronics, 90, 558-576(2017).

33. V. S. Sarathi and K. S. Nahm, Recent advances and challenges in the anode architecture and their modifications for the applications of microbial fuel cells, Biosensors and Bioelectronics, 43, 461-475(2013).

34. X. Quan, H. Xu, B. Sun, Z. Xiao, Anode modification with palladium nanoparticles enhanced Evans Blue removal and power generation in microbial fuel cells, International biodeterioration \& biodegradation, 132, 94-101(2018).

35. M. Jarosz, J. Grudzień, K. Kamiński, K. Gawlak, K. Wolski, M. Nowakowska, G. D. Sulka, Novel bioelectrodes based on polysaccharide modified gold surfaces and electrochemically active Lactobacillus rhamnosus GG biofilms, Electrochimica Acta, 296, 999-1008(2019).

36. D. Zhong, X. Liao, Y. Liu, N. Zhong, Y. Xu, Enhanced electricity generation performance and dye wastewater degradation of microbial fuel cell by using a petaline $\mathrm{NiO} @$ polyaniline-carbon felt anode, Bioresource technology, 258, 125-134(2018).

37. S. Phonsa, P. Sreearunothai, S. Charojrochkul, K. Sombatmankhong, Electrodeposition of $\mathrm{MnO} 2$ on polypyrrolecoated stainless steel to enhance electrochemical activities in microbial fuel cells, Solid State Ionics, 316, 125-134(2018).

38. M. Gao, X. Liu, M. Irfan, J. Shi, X. Wang, P. Zhang, Nickle-cobalt composite catalyst-modified activated carbon anode for direct glucose alkaline fuel cell, International Journal of Hydrogen Energy, 43(3), 1805-1815(2018).

39. X. Ying, D. Shen, M. Wang, H. Feng, Y. Gu, W. Chen, Titanium dioxide thin film-modified stainless steel mesh for enhanced current-generation in microbial fuel cells, Chemical Engineering Journal, 333, 260-267(2018).

40. J. L. Varanasi, A. K. Nayak, Y. Sohn, D. Pradhan, D. Das, Improvement of power generation of microbial fuel cell by integrating tungsten oxide electrocatalyst with pure or mixed culture biocatalysts, Electrochimica Acta, 199, 154-163(2016).

41. L. Zeng, W. Zhang, P. Xia, W. Tu, C. Ye, M. He, Porous Ni0. 1Mn0. 9O1. 45 microellipsoids as high-performance anode electrocatalyst for microbial fuel cells, Biosensors and Bioelectronics, 102, 351-356(2018).

42. E. Taşkan, S. Bulak, B. Taşkan, M. Şaşmaz, S. El Abed, A. El Abed, Nitinol as a suitable anode material for electricity generation in microbial fuel cells, Bioelectrochemistry, 128,
118-125(2019).

43. R. Rani, D. Sharma, S. Kumar, Optimization of operating conditions of miniaturize single chambered microbial fuel cell using NiWO4/graphene oxide modified anode for performance improvement and microbial communities dynamics, Bioresource technology, 285, 121337(2019).

44. K.-B. Pu, Q. Ma, W.-F. Cai, Q.-Y. Chen, Y.-H. Wang, F.-J. $\mathrm{Li}$, Polypyrrole modified stainless steel as high performance anode of microbial fuel cell, Biochemical engineering journal, 132, 255-261(2018).

45. A. J. Slate, K. A. Whitehead, D. A. Brownson, C. E. Banks, Microbial fuel cells: An overview of current technology, Renewable and sustainable energy reviews, 101, 60-81(2019).

46. E. Antolini, Nitrogen-doped carbons by sustainable $\mathrm{N}$-and $\mathrm{C}$-containing natural resources as nonprecious catalysts and catalyst supports for low temperature fuel cells, Renewable and Sustainable Energy Reviews, 58, 34-51(2016).

47. L. Zhang, W. He, J. Yang, J. Sun, H. Li, B. Han, S. Zhao, Y. Shi, Y. Feng, Z. Tang, Bread-derived 3D macroporous carbon foams as high performance free-standing anode in microbial fuel cells, Biosensors and Bioelectronics, 122, 217-223(2018).

48. T. Cai, M. Huang, Y. Huang, W. Zheng, Enhanced performance of microbial fuel cells by electrospinning carbon nanofibers hybrid carbon nanotubes composite anode, International journal of hydrogen energy, 44(5), 3088-3098(2019).

49. A. ElMekawy, H. M. Hegab, D. Losic, C. P. Saint, D. Pant, Applications of graphene in microbial fuel cells: the gap between promise and reality, Renewable and Sustainable Energy Reviews, 72, 1389-1403(2017).

50. B. Koo, S. P. Jung, Recent Trends of Oxygen Reduction Catalysts in Microbial Fuel Cells: A Review, J Korean Soc Environ Eng, 41(11), 657-675(2019).

51. H. Dong, H. Yu, X. Wang, Catalysis kinetics and porous analysis of rolling activated carbon-PTFE air-cathode in microbial fuel cells, Environmental science \& technology, 46(23), 13009-13015(2012).

52. S. Cheng, H. Liu, B. E. Logan, Increased performance of single-chamber microbial fuel cells using an improved cathode structure, Electrochemistry communications, 8(3), 489-494(2006).

53. F. Zhang, S. Cheng, D. Pant, G. Van Bogaert, B. E. Logan, Power generation using an activated carbon and metal mesh cathode in a microbial fuel cell, Electrochemistry Communications, 11(11), 2177-2179(2009).

54. T. Saito, M. D. Merrill, V. J. Watson, B. E. Logan, M. A. Hickner, Investigation of ionic polymer cathode binders for microbial fuel cells, Electrochimica Acta, 55(9), 3398-3403 (2010).

55. S. Son, B. Koo, H. Chai, H. V. H. Tran, S. Pandit, S. P. Jung, Comparison of hydrogen production and system performance in a microbial electrolysis cell containing cathodes made of non-platinum catalysts and binders, 
Journal of Water Process Engineering, 40, 101844(2021).

56. A. Kraytsberg and Y. Ein-Eli, Review of advanced materials for proton exchange membrane fuel cells, Energy \& Fuels, 28(12), 7303-7330(2014).

57. W. Yang, W. He, F. Zhang, M. A. Hickner, B. E. Logan, Single-step fabrication using a phase inversion method of poly (vinylidene fluoride)(PVDF) activated carbon air cathodes for microbial fuel cells, Environmental Science \& Technology Letters, 1(10), 416-420(2014).

58. R. A. Rozendal, E. Leone, J. Keller, K. Rabaey, Efficient hydrogen peroxide generation from organic matter in a bioelectrochemical system, Electrochemistry Communications, 11(9), 1752-1755(2009).

59. S. G. Peera, T. Maiyalagan, C. Liu, S. Ashmath, T. G. Lee, Z. Jiang, S. Mao, A review on carbon and non-precious metal based cathode catalysts in microbial fuel cells, International Journal of Hydrogen Energy, 46(4), 3056-3089(2021).

60. S. Gouse Peera, K. K. Tintula, A. K. Sahu, S. Shanmugam, P. Sridhar, S. Pitchumani, Catalytic activity of Pt anchored onto graphite nanofiber-poly (3,4-ethylenedioxythiophene) composite toward oxygen reduction reaction in polymer electrolyte fuel cells, Electrochimica Acta, 108, 95-103(2013).

61. S. G. Peera, A. K. Sahu, A. Arunchander, S. D. Bhat, J. Karthikeyan, P. Murugan, Nitrogen and fluorine co-doped graphite nanofibers as high durable oxygen reduction catalyst in acidic media for polymer electrolyte fuel cells, Carbon, 93, 130-142(2015).

62. S. G. Peera, A. Arunchander, A. K. Sahu, Platinum nanoparticles supported on nitrogen and fluorine co-doped graphite nanofibers as an excellent and durable oxygen reduction catalyst for polymer electrolyte fuel cells, Carbon, 107, 667-679(2016).

63. G. P. Shaik, H.-J. Kwon, T. G. Lee, Highly efficient Co@NCS nanosheet electrocatalyst for oxygen reduction reaction: An environment-friendly, low-cost and sustainable electrocatalyst, Materials Research Bulletin, 128, 110873(2020).

64. S. G. Peera, J. Balamurugan, N. H. Kim, J. H. Lee, Sustainable Synthesis of Co@NC Core Shell Nanostructures from Metal Organic Frameworks via Mechanochemical Coordination Self-Assembly: An Efficient Electrocatalyst for Oxygen Reduction Reaction, Small, 14(19), 1800441(2018).

65. A. Arunchander, S. G. Peera, S. K. Panda, S. Chellammal, A. K. Sahu, Simultaneous co-doping of $\mathrm{N}$ and $\mathrm{S}$ by a facile in-situ polymerization of 6-N,N-dibutylamine-1,3,5-triazine2,4-dithiol on graphene framework: An efficient and durable oxygen reduction catalyst in alkaline medium, Carbon, 118, 531-544(2017).

66. S. Cheng, H. Liu, B. E. Logan, Power densities using different cathode catalysts (Pt and CoTMPP) and polymer binders (Nafion and PTFE) in single chamber microbial fuel cells, Environmental science \& technology, 40(1), 364-369 (2006).

67. M. Rahimnejad, A. Adhami, S. Darvari, A. Zirepour, S.-E. $\mathrm{Oh}$, Microbial fuel cell as new technology for bioelectricity generation: A review, Alexandria Engineering Journal, 54(3),
745-756(2015).

68. Y. Zhang, J. Sun, Y. Hu, S. Li, Q. Xu, Bio-cathode materials evaluation in microbial fuel cells: a comparison of graphite felt, carbon paper and stainless steel mesh materials, International Journal of Hydrogen Energy, 37(22), 16935-16942(2012).

69. S. Samad, K. S. Loh, W. Y. Wong, T. K. Lee, J. Sunarso, S. T. Chong, W. R. W. Daud, Carbon and non-carbon support materials for platinum-based catalysts in fuel cells, international journal of hydrogen energy, 43(16), 7823-7854 (2018).

70. B. Erable, N. Duteanu, S. S. Kumar, Y. Feng, M. M. Ghangrekar, K. Scott, Nitric acid activation of graphite granules to increase the performance of the non-catalyzed oxygen reduction reaction (ORR) for MFC applications, Electrochemistry communications, 11(7), 1547-1549(2009).

71. R. T. Khajeh, S. Aber, K. Nofouzi, Efficient improvement of microbial fuel cell performance by the modification of graphite cathode via electrophoretic deposition of $\mathrm{CuO} / \mathrm{ZnO}$, Materials Chemistry and Physics, 240, 122208(2020).

72. Y. Yuan, J. Ahmed, S. Kim, Polyaniline/carbon black composite-supported iron phthalocyanine as an oxygen reduction catalyst for microbial fuel cells, Journal of Power Sources, 196(3), 1103-1106(2011).

73. X. Wang, C. Yuan, C. Shao, S. Zhuang, J. Ye, B. Li, Enhancing oxygen reduction reaction by using metal-free nitrogen-doped carbon black as cathode catalysts in microbial fuel cells treating wastewater, Environmental research, 182, 109011(2020).

74. X. Zhang, Q. Wang, X. Xia, W. He, X. Huang, B. E. Logan, Addition of conductive particles to improve the performance of activated carbon air-cathodes in microbial fuel cells, Environmental Science: Water Research \& Technology, 3(5), 806-810(2017).

75. B. Koo, H. Kang, T. Nam, E. Kim, S. Son, S. P. Jung, Performance Enhancement of a Microbial Fuel Cell by Physico-chemical Treatments of Activated-Carbon Catalyst of an Air Cathode, Journal of the Korean Society of Urban Environment 16(4), 431-439(2016).

76. Q. Yang, X. Zhao, J. Yang, B. Zhou, J. Wang, Y. Dong, H. Zhao, Welding assembly of 3D interconnected carbon nanotubes on carbon fiber as the high-performance anode of microbial fuel cells, International Journal of Hydrogen Energy, 44(36), 20304-20311(2019).

77. U. Karra, S. S. Manickam, J. R. McCutcheon, N. Patel, B. $\mathrm{Li}$, Power generation and organics removal from wastewater using activated carbon nanofiber (ACNF) microbial fuel cells (MFCs), International journal of hydrogen energy, 38(3), 1588-1597(2013).

78. L. Deng, M. Zhou, C. Liu, L. Liu, C. Liu, S. Dong, Development of high performance of $\mathrm{Co} / \mathrm{Fe} / \mathrm{N} / \mathrm{CNT}$ nanocatalyst for oxygen reduction in microbial fuel cells, Talanta, 81(1-2), 444-448(2010)

79. Y. Zhang, Y. Hu, S. Li, J. Sun, B. Hou, Manganese dioxide-coated carbon nanotubes as an improved cathodic 
catalyst for oxygen reduction in a microbial fuel cell, Journal of Power Sources, 196(22), 9284-9289(2011).

80. J. C. Wu, W. M. Yan, W. H. Chiang, S. Thangavel, C. H. Wang, C. T. Wang, Innovative multi processed $\mathrm{N}$ doped carbon and $\mathrm{Fe}_{3} \mathrm{O}_{4}$ cathode for enhanced bioelectro Fenton microbial fuel cell performance, International Journal of Energy Research, 43(13), 7594-7603(2019).

81. C. Zhang, P. Liang, X. Yang, Y. Jiang, Y. Bian, C. Chen, $\mathrm{X}$. Zhang, $\mathrm{X}$. Huang, Binder-free graphene and manganese oxide coated carbon felt anode for high-performance microbial fuel cell, Biosensors and Bioelectronics, 81, 32-38(2016).

82. M. Kannan, Current status, key challenges and its solutions in the design and development of graphene based ORR catalysts for the microbial fuel cell applications, Biosensors and Bioelectronics, 77, 1208-1220(2016).

83. F. Yu, C. Wang, J. Ma, Capacitance-enhanced 3D graphene anode for microbial fuel cell with long-time electricity generation stability, Electrochimica Acta, 259, 1059-1067 (2018).

84. L. Zhuang, Y. Yuan, G. Yang, S. Zhou, In situ formation of graphene/biofilm composites for enhanced oxygen reduction in biocathode microbial fuel cells, Electrochemistry Communications, 21, 69-72(2012).

85. J. Liu, Y. Zhang, Y. Li, J. Li, Z. Chen, H. Feng, J. Li, J. Jiang, D. Qian, In situ chemical synthesis of sandwich-structured $\mathrm{MnO}$ a- $\mathrm{MnO}_{2} /$ graphene nanoflowers and their supercapacitive behavior, Electrochimica Acta, 173, 148-155(2015).

86. P. Pachfule, D. Shinde, M. Majumder, Q. Xu, Fabrication of carbon nanorods and graphene nanoribbons from a metal-organic framework, Nature Chemistry, 8(7), 718-724(2016).

87. L. Tan, S.-J. Li, X.-T. Wu, N. Li, Z.-Q. Liu, Porous $\mathrm{Co}_{3} \mathrm{O}_{4}$ decorated nitrogen-doped graphene electrocatalysts for efficient bioelectricity generation in MFCs, International Journal of Hydrogen Energy, 43(22), 10311-10321(2018).

88. A. A. Eissa, S. G. Peera, N. H. Kim, J. H. Lee, g-C3N4 templated synthesis of the Fe3C@NSC electrocatalyst enriched with $\mathrm{Fe}-\mathrm{Nx}$ active sites for efficient oxygen reduction reaction, Journal of Materials Chemistry A, 7(28), 16920-16936(2019)

89. U. I. Kramm, J. Herranz, N. Larouche, T. M. Arruda, M. Lefevre, F. Jaouen, P. Bogdanoff, S. Fiechter, I. Abs-Wurmbach, S. Mukerjee, Structure of the catalytic sites in $\mathrm{Fe} / \mathrm{N} / \mathrm{C}$-catalysts for $\mathrm{O}_{2}$-reduction in PEM fuel cells, Physical Chemistry Chemical Physics, 14(33), 11673-11688 (2012).

90. Q. Jia, N. Ramaswamy, H. Hafiz, U. Tylus, K. Strickland, G. Wu, B. Barbiellini, A. Bansil, E. F. Holby, P. Zelenay, Experimental observation of redox-induced $\mathrm{Fe}-\mathrm{N}$ switching behavior as a determinant role for oxygen reduction activity, ACS nano, 9(12), 12496-12505(2015).

91. S. Rojas-Carbonell, C. Santoro, A. Serov, P. Atanassov, Transition metal-nitrogen-carbon catalysts for oxygen reduction reaction in neutral electrolyte, Electrochemistry Communications, 75, 38-42(2017).
92. W. Yang, X. Wang, R. Rossi, B. E. Logan, Low-cost Fe-N-C catalyst derived from Fe (III)-chitosan hydrogel to enhance power production in microbial fuel cells, Chemical Engineering Journal, 380, 122522(2020).

93. B. Koo and S. P. Jung, Improvement of air cathode performance in microbial fuel cells by using catalysts made by binding metal-organic framework and activated carbon through ultrasonication and solution precipitation, Chemical Engineering Journal, 424, 130388(2021).

94. W. Xue, Q. Zhou, F. Li, B. S. Ondon, Zeolitic imidazolate framework-8 (ZIF-8) as robust catalyst for oxygen reduction reaction in microbial fuel cells, Journal of Power Sources, 423, 9-17(2019).

95. S. Venkata Mohan, G. Velvizhi, J. Annie Modestra, S. Srikanth, Microbial fuel cell: Critical factors regulating bio-catalyzed electrochemical process and recent advancements, Renewable and Sustainable Energy Reviews, 40, 779-797(2014).

96. T. Sadhasivam, K. Dhanabalan, S.-H. Roh, T.-H. Kim, K.-W. Park, S. Jung, M. D. Kurkuri, H.-Y. Jung, A comprehensive review on unitized regenerative fuel cells: Crucial challenges and developments, International Journal of Hydrogen Energy, 42(7), 4415-4433(2017).

97. H. Kang, J. Jeong, P. L. Gupta, S. P. Jung, Effects of brush-anode configurations on performance and electrochemistry of microbial fuel cells, international journal of hydrogen energy, 42(45), 27693-27700(2017).

98. Y. Ahn, B. E. Logan, A multi-electrode continuous flow microbial fuel cell with separator electrode assembly design, Applied microbiology and biotechnology, 93(5), 2241-2248 (2012).

99. T. Luo, S. Abdu, M. Wessling, Selectivity of ion exchange membranes: A review, Journal of membrane science, 555, 429-454(2018).

100. S. M. Daud, B. H. Kim, M. Ghasemi, W. R. W. Daud, Separators used in microbial electrochemical technologies: Current status and future prospects, Bioresource Technology, 195, 170-179(2015)

101. S. M. Daud, W. R. W. Daud, B. H. Kim, M. R. Somalu, M. H. A. Bakar, A. Muchtar, J. M. Jahim, S. S. Lim, I. S. Chang, Comparison of performance and ionic concentration gradient of two-chamber microbial fuel cell using ceramic membrane (CM) and cation exchange membrane (CEM) as separators, Electrochimica Acta, 259, 365-376(2018).

102. F. Harnisch and U. Schröder, Selectivity versus mobility: separation of anode and cathode in microbial bioelectrochemical systems, ChemSusChem: Chemistry \& Sustainability Energy \& Materials, 2(10), 921-926(2009).

103.W.-W. Li, G.-P. Sheng, X.-W. Liu, H.-Q. Yu, Recent advances in the separators for microbial fuel cells, Bioresource technology, 102(1), 244-252(2011).

104. M. Buonomenna and J. Bae, Membrane processes and renewable energies, Renewable and Sustainable Energy Reviews, 43, 1343-1398(2015).

105. S. Choi, J. R. Kim, J. Cha, Y. Kim, G. C. Premier, C. Kim, 
Enhanced power production of a membrane electrode assembly microbial fuel cell (MFC) using a cost effective poly [2, 5-benzimidazole](ABPBI) impregnated non-woven fabric filter, Bioresource technology, 128, 14-21(2013).

106. R. A. Rozendal, T. H. J. A. Sleutels, H. V. Hamelers, C. J. Buisman, Effect of the type of ion exchange membrane on performance, ion transport, and $\mathrm{pH}$ in biocatalyzed electrolysis of wastewater, Water Science and Technology, 57(11), 1757-1762(2008).

107. B. Christgen, K. Scott, J. Dolfing, I. M. Head, T. P. Curtis, An evaluation of the performance and economics of membranes and separators in single chamber microbial fuel cells treating domestic wastewater, PLoS One, 10(8), e0136108(2015).

108. C. Abourached, M. J. English, H. Liu, Wastewater treatment by microbial fuel cell (MFC) prior irrigation water reuse, Journal of Cleaner Production, 137, 144-149(2016).

109. Y. Fan, H. Hu, H. Liu, Enhanced Coulombic efficiency and power density of air-cathode microbial fuel cells with an improved cell configuration, Journal of Power Sources, 171(2), 348-354(2007).

110. Y. Park, S. Park, J. Yu, T. Lee, Effects of anode spacing and flow rate on energy recovery of flat-panel air-cathode microbial fuel cells using domestic wastewater, Bioresource technology, 258, 57-63(2018).

111. Y. Park, J. Yu, E. Widyaningsih, T. Lee, Effect of reactor width and HRT on simultaneous removal of organic compounds and nitrogen in flat-type air-cathode microbial fuel cell, Journal of Korean society of environmental engineers, 41(2), 69-75(2019).

112. C. Munoz-Cupa, Y. Hu, C. C. Xu, A. Bassi, An overview of microbial fuel cell usage in wastewater treatment, resource recovery and energy production, Science of the Total Environment, 142429(2020).

113. J. X. Leong, W. R. W. Daud, M. Ghasemi, K. B. Liew, M. Ismail, Ion exchange membranes as separators in microbial fuel cells for bioenergy conversion: A comprehensive review, Renewable and Sustainable Energy Reviews, 28, 575-587(2013).

114. E. Yang, K.-J. Chae, M.-J. Choi, Z. He, I. S. Kim, Critical review of bioelectrochemical systems integrated with membrane-based technologies for desalination, energy self-sufficiency, and high-efficiency water and wastewater treatment, Desalination, 452, 40-67(2019).

115. Q. Xu, L. Wang, C. Li, X. Wang, C. Li, Y. Geng, Study on improvement of the proton conductivity and anti-fouling of proton exchange membrane by doping $\mathrm{SGO} @ \mathrm{SiO}_{2}$ in microbial fuel cell applications, International Journal of Hydrogen Energy, 44(29), 15322-15332(2019).

116. S. G. Flimban, S. H. Hassan, M. M. Rahman, S.-E. Oh, The effect of Nafion membrane fouling on the power generation of a microbial fuel cell, international journal of hydrogen energy, 45(25), 13643-13651(2020).

117. W. He, Y. Dong, C. Li, X. Han, G. Liu, J. Liu, Y. Feng, Field tests of cubic-meter scale microbial electrochemical system in a municipal wastewater treatment plant, Water research, 155, 372-380(2019).

118. M. Oliot, S. Galier, H. Roux de Balmann, A. Bergel, Ion transport in microbial fuel cells: Key roles, theory and critical review, Applied Energy, 183, 1682-1704(2016).

119. S. Jung, M. M. Mench, J. M. Regan, Impedance characteristics and polarization behavior of a microbial fuel cell in response to short-term changes in medium $\mathrm{pH}$, Environmental science \& technology, 45(20), 9069-9074 (2011).

120. B. Koo, S.-M. Lee, S.-E. Oh, E. J. Kim, Y. Hwang, D. Seo, J. Y. Kim, Y. H. Kahng, Y. W. Lee, S.-Y. Chung, Addition of reduced graphene oxide to an activated-carbon cathode increases electrical power generation of a microbial fuel cell by enhancing cathodic performance, Electrochimica Acta, 297, 613-622(2019).

121. T. Nam, H. Kang, S. Pandit, S.-H. Kim, S. Yoon, S. Bae, S. P. Jung, Effects of vertical and horizontal configurations of different numbers of brush anodes on performance and electrochemistry of microbial fuel cells, Journal of Cleaner Production, 277, 124125(2020).

122. T. Nam, S. Son, E. Kim, H. V. H. Tran, B. Koo, H. Chai, J. Kim, S. Pandit, A. Gurung, S.-E. Oh, Improved structures of stainless steel current collector increase power generation of microbial fuel cells by decreasing cathodic charge transfer impedance, Environmental Engineering Research, 23(4), 383-389(2018).

123. B. P. Cario, R. Rossi, K.-Y. Kim, B. E. Logan, Applying the electrode potential slope method as a tool to quantitatively evaluate the performance of individual microbial electrolysis cell components, Bioresource technology, 287, 121418(2019).

124. M. Á. López Zavala, O. I. Gonzalez Pena, H. Cabral Ruelas, C. Delgado Mena, M. Guizani, Use of cyclic voltammetry to describe the electrochemical behavior of a dual-chamber microbial fuel cell, Energies, 12(18), 3532(2019).

125. J. N. Roy, H. R. Luckarift, C. Lau, A. Falase, K. E. Garcia, L. K. Ista, P. Chellamuthu, R. P. Ramasamy, V. Gadhamshetty, G. Wanger, A study of the flavin response by Shewanella cultures in carbon-limited environments, Rsc Advances, 2(26), 10020-10027(2012).

126. K. Fricke, F. Harnisch, U. Schröder, On the use of cyclic voltammetry for the study of anodic electron transfer in microbial fuel cells, Energy \& Environmental Science, 1(1), 144-147(2008).

127. Y. Yuan, S. Zhou, N. Xu, L. Zhuang, Electrochemical characterization of anodic biofilms enriched with glucose and acetate in single-chamber microbial fuel cells, Colloids and Surfaces B: Biointerfaces, 82(2), 641-646(2011).

128. Z. He and F. Mansfeld, Exploring the use of electrochemical impedance spectroscopy (EIS) in microbial fuel cell studies, Energy \& Environmental Science, 2(2), 215-219(2009).

129. N. Sekar and R. P. Ramasamy, Electrochemical impedance spectroscopy for microbial fuel cell characterization, J. Microb. Biochem. Technol. S, 6(2)(2013).

130. B. E. Logan, D. Call, S. Cheng, H. V. Hamelers, T. H. 
Sleutels, A. W. Jeremiasse, R. A. Rozendal, Microbial electrolysis cells for high yield hydrogen gas production from organic matter, Environmental science \& technology, 42(23), 8630-8640(2008).

131.D. Call and B. E. Logan, Hydrogen production in a single chamber microbial electrolysis cell lacking a membrane, Environmental science \& technology, 42(9), 3401-3406(2008).

132. P. S. Jana, M. Behera, M. Ghangrekar, Performance comparison of up-flow microbial fuel cells fabricated using proton exchange membrane and earthen cylinder, International Journal of Hydrogen Energy, 35(11), 5681-5686(2010).

133. J. Choi and Y. Ahn, Effect of hydrogen producing mixed culture on performance of microbial fuel cells, International journal of hydrogen energy, 39(17), 9482-9489(2014).

134. J. L. Varanasi, S. Roy, S. Pandit, D. Das, Improvement of energy recovery from cellobiose by thermophillic dark fermentative hydrogen production followed by microbial fuel cell, international journal of hydrogen energy, 40(26), 8311-8321(2015).

135. M. Li, K. Lv, S. Wu, S. Chen, Immobilization of Anodophilic Biofilms for Use in Aerotolerant Bioanodes of Microbial Fuel Cells, ACS applied materials \& interfaces, 8(51), 34985-34990(2016).

136.Z. Ge, J. Li, L. Xiao, Y. Tong, Z. He, Recovery of electrical energy in microbial fuel cells: brief review, Environmental Science \& Technology Letters, 1(2), 137-141(2014).

137. J. Öijerholm, S. Forsberg, H. Hermansson, M. Ullberg, Relation Between the SHE and the Internal $\mathrm{Ag} / \mathrm{AgCl}$ Reference Electrode at High Temperatures, Journal of the Electrochemical Society, 156(3), P56(2009).

138. A. Bard, R. Parsons, J. Jordan, Standard potentials in aqueous solution. Marcel Dekker, New York, Standard potentials in aqueous solution. Marcel Dekker, New York., (1985).

139. H. J. Kim, H. S. Park, M. S. Hyun, I. S. Chang, M. Kim, B. H. Kim, A mediator-less microbial fuel cell using a metal reducing bacterium, Shewanella putrefaciens, Enzyme and Microbial technology, 30(2), 145-152(2002).

140. G.-C. Gil, I.-S. Chang, B. H. Kim, M. Kim, J.-K. Jang, H. S. Park, H. J. Kim, Operational parameters affecting the performannce of a mediator-less microbial fuel cell, Biosensors and Bioelectronics, 18(4), 327-334(2003).

141.D. H. Park, J. G. Zeikus, Improved fuel cell and electrode designs for producing electricity from microbial degradation, Biotechnology and bioengineering, 81(3), 348-355(2003).

142. H. Liu, B. E. Logan, Electricity generation using an air-cathode single chamber microbial fuel cell in the presence and absence of a proton exchange membrane, Environmental science \& technology, 38(14), 4040-4046(2004).

143.Z. He, S. D. Minteer, L. T. Angenent, Electricity generation from artificial wastewater using an upflow microbial fuel cell, Environmental science \& technology, 39(14), 5262-5267 (2005).

144. H. Liu, S. Cheng, B. E. Logan, Power generation in fed-batch microbial fuel cells as a function of ionic strength, temperature, and reactor configuration, Environmental science \& technology, 39(14), 5488-5493(2005).

145.Z. He, L. T. Angenent, Application of bacterial biocathodes in microbial fuel cells, Electroanalysis: An International Journal Devoted to Fundamental and Practical Aspects of Electroanalysis, 18(19 20), 2009-2015(2006).

146. P. Aelterman, K. Rabaey, H. T. Pham, N. Boon, W. Verstraete, Continuous electricity generation at high voltages and currents using stacked microbial fuel cells, Environmental science \& technology, 40(10), 3388-3394(2006).

147. B. Logan, S. Cheng, V. Watson, G. Estadt, Graphite fiber brush anodes for increased power production in air-cathode microbial fuel cells, Environmental science \& technology, 41(9), 3341-3346(2007).

148. S. You, Q. Zhao, J. Zhang, J. Jiang, C. Wan, M. Du, S. Zhao, A graphite-granule membrane-less tubular air-cathode microbial fuel cell for power generation under continuously operational conditions, Journal of Power Sources, 173(1), 172-177(2007).

149. Y. Qiao, C. M. Li, S.-J. Bao, Q.-L. Bao, Carbon nanotube/polyaniline composite as anode material for microbial fuel cells, Journal of Power Sources, 170(1), 79-84(2007).

150. S. Cheng,B. E. Logan, Ammonia treatment of carbon cloth anodes to enhance power generation of microbial fuel cells, Electrochemistry Communications, 9(3), 492-496(2007).

151. D. Pant, A. Singh, G. Van Bogaert, S. I. Olsen, P. S. Nigam, L. Diels, K. Vanbroekhoven, Bioelectrochemical systems (BES) for sustainable energy production and product recovery from organic wastes and industrial wastewaters, Rsc Advances, 2(4), 1248-1263(2012).

152. Y. Fan, H. Hu, H. Liu, Sustainable power generation in microbial fuel cells using bicarbonate buffer and proton transfer mechanisms, Environmental science \& technology, 41(23), 8154-8158(2007).

153. H. Tang, S. Cai, S. Xie, Z. Wang, Y. Tong, M. Pan, X. Lu, Metal-organic framework derived dual metal and nitrogen doped carbon as efficient and robust oxygen reduction reaction catalysts for microbial fuel cells, Advanced science, 3(2), 1500265(2016).

154. Y. Wang, C. He, W. Li, W. Zong, Z. Li, L. Yuan, G. Wang, $\mathrm{Y}$. $\mathrm{Mu}$, High power generation in mixed-culture microbial fuel cells with corncob-derived three-dimensional $\mathrm{N}$-doped bioanodes and the impact of $\mathrm{N}$ dopant states, Chemical Engineering Journal, 399, 125848(2020).

155. S. Pandit, N. Savla, S. P. Jung, Recent advancements in scaling up microbial fuel cells, Integrated Microbial Fuel Cells for Wastewater Treatment, 349-368(2020).

156. I. Ieropoulos, J. Greenman, C. Melhuish, Improved energy output levels from small-scale microbial fuel cells, Bioelectrochemistry, 78(1), 44-50(2010).

157. A. Dewan, H. Beyenal, Z. Lewandowski, Scaling up microbial fuel cells, Environmental science \& technology, 42(20), 7643-7648(2008).

158. P. Clauwaert, P. Aelterman, L. De Schamphelaire, M. Carballa, K. Rabaey, W. Verstraete, Minimizing losses in bio-electrochemical 
systems: the road to applications, Applied microbiology and biotechnology, 79(6), 901-913(2008).

159.X. A. Walter, C. Santoro, J. Greenman, I. A. Ieropoulos, Scalability and stacking of self-stratifying microbial fuel cells treating urine, Bioelectrochemistry, 133, 107491(2020).

160. Y. Feng, W. He, J. Liu, X. Wang, Y. Qu, N. Ren, A horizontal plug flow and stackable pilot microbial fuel cell for municipal wastewater treatment, Bioresource technology, 156, 132-138(2014).

161. B. E. Logan, M. J. Wallack, K.-Y. Kim, W. He, Y. Feng, P. E. Saikaly, Assessment of Microbial Fuel Cell Configurations and Power Densities, Environmental Science \& Technology Letters, 2(8), 206-214(2015).

162. F. Qian, M. Baum, Q. Gu, D. E. Morse, A $1.5 \mu \mathrm{L}$ microbial fuel cell for on-chip bioelectricity generation, Lab on a Chip, 9(21), 3076-3081(2009).

163. A. Dekker, A. T. Heijne, M. Saakes, H. V. Hamelers, C. J. Buisman, Analysis and improvement of a scaled-up and stacked microbial fuel cell, Environmental science \& technology, 43(23), 9038-9042(2009).

164. B. Koo, S.-M. Lee, S.-E. Oh, E. J. Kim, Y. Hwang, D. Seo, J. Y. Kim, Y. H. Kahng, Y. W. Lee, S.-Y. Chung, S.-J. Kim, J. H. Park, S. P. Jung, Addition of reduced graphene oxide to an activated-carbon cathode increases electrical power generation of a microbial fuel cell by enhancing cathodic performance, Electrochimica Acta, 297, 613-622(2019).

165.Z. Ge, F. Zhang, J. Grimaud, J. Hurst, Z. He, Long-term investigation of microbial fuel cells treating primary sludge or digested sludge, Bioresource Technology, 136, 509-514(2013).

166. K. Guo, A. Prévoteau, K. Rabaey, A novel tubular microbial electrolysis cell for high rate hydrogen production, Journal of Power Sources, 356, 484-490(2017).

167. S. Cheng, B. E. Logan, Increasing power generation for scaling up single-chamber air cathode microbial fuel cells, Bioresource technology, 102(6), 4468-4473(2011).

168. S. J. Robertson, M. Grattieri, J. Behring, M. Bestetti, S. D. Minteer, Transitioning from batch to flow hypersaline microbial fuel cells, Electrochimica Acta, 317, 494-501(2019).

169. B.-M. An, S.-j. Seo, S. Hidayat, J.-Y. Park, Treatment of ethanolamine and electricity generation using a scaled-up single-chamber microbial fuel cell, Journal of Industrial and Engineering Chemistry, 81, 1-6(2020).

170. K. Bonyoung, P. J. Sokhee, Characterization of Impedance and Polarization of Carbon-Felt Bioanodes and Activated-Carbon Cathodes in a Continuous-Flow Microbial Fuel Cell, Journal of the Korean Society of Urban Environment, 18(2), 177-191(2018).

171.L. Caizán-Juanarena, I. Servin-Balderas, X. Chen, C. J. Buisman, A. ter Heijne, Electrochemical and microbiological characterization of single carbon granules in a multi-anode microbial fuel cell, Journal of Power Sources, 435, 126514(2019).

172. Y. Liu, X. Sun, D. Yin, L. Cai, L. Zhang, Suspended anode-type microbial fuel cells for enhanced electricity generation, RSC
Advances, 10(17), 9868-9877(2020).

173. J. V. Boas, V. Oliveira, L. Marcon, M. Simões, A. Pinto, Optimization of a single chamber microbial fuel cell using Lactobacillus pentosus: Influence of design and operating parameters, Science of The Total Environment, 648, 263-270(2019).

174. R. Rossi, D. Jones, J. Myung, E. Zikmund, W. Yang, Y. A. Gallego, D. Pant, P. J. Evans, M. A. Page, D. M. Cropek, Evaluating a multi-panel air cathode through electrochemical and biotic tests, Water research, 148, 51-59(2019).

175. R. Rossi, P. J. Evans, B. E. Logan, Impact of flow recirculation and anode dimensions on performance of a large scale microbial fuel cell, Journal of power sources, 412, 294-300(2019).

176. Y. Dong, W. He, C. Li, D. Liang, Y. Qu, X. Han, Y. Feng, Performance of integrated bioelectrochemical membrane reactor: Energy recovery, pollutant removal and membrane fouling alleviation, Journal of Power Sources, 384, 178-186(2018).

177. C. Li, W. He, D. Liang, Y. Tian, R. S. Yadav, D. Li, J. Liu, Y. Feng, The anaerobic and starving treatment eliminates filamentous bulking and recovers biocathode biocatalytic activity with residual organic loading in microbial electrochemical system, Chemical Engineering Journal, 404, 127072(2021).

178. I. A. Ieropoulos, A. Stinchcombe, I. Gajda, S. Forbes, I. Merino-Jimenez, G. Pasternak, D. Sanchez-Herranz, J. Greenman, Pee power urinal - microbial fuel cell technology field trials in the context of sanitation, Environmental Science: Water Research \& Technology, 2(2), 336-343(2016).

179. J. Niu, Y. Feng, N. Wang, S. Liu, Y. Liang, J. Liu, W. He, Effects of high ammonia loading and in-situ short-cut nitrification in low carbon nitrogen ratio wastewater treatment by biocathode microbial electrochemical system, Science of The Total Environment, 755, 142641(2021).

180. H. Wang, Z. Miao, Y. Li, W. He, Y. Qu, Y. Feng, Energetically self-sustaining treatment of swine wastewater in a microbial electrochemical technology-centered hybrid system, Environmental Science: Water Research \& Technology, 6(3), 747-756(2020).

181. S. Liu, Y. Feng, J. Niu, J. Liu, N. Li, W. He, A novel single chamber vertical baffle flow biocathode microbial electrochemical system with microbial separator, Bioresource technology, 294, 122236(2019).

182. I. Ieropoulos, J. Greenman, C. Melhuish, Microbial fuel cells based on carbon veil electrodes: Stack configuration and scalability, International Journal of Energy Research, 32(13), 1228-1240(2008).

183.Z. Liu, J. Liu, S. Zhang, Z. Su, A novel configuration of microbial fuel cell stack bridged internally through an extra cation exchange membrane, Biotechnology Letters, 30(6), 1017-1023(2008).

184. L. Zhuang, Y. Zheng, S. Zhou, Y. Yuan, H. Yuan, Y. Chen, Scalable microbial fuel cell (MFC) stack for continuous real wastewater treatment, Bioresource technology, 106, 82-88 (2012). 
185. L. Zhuang, Y. Yuan, Y. Wang, S. Zhou, Long-term evaluation of a 10-liter serpentine-type microbial fuel cell stack treating brewery wastewater, Bioresource Technology, 123, 406-412(2012).

186. I. Gajda, O. Obata, M. Jose Salar-Garcia, J. Greenman, I. A. Ieropoulos, Long-term bio-power of ceramic microbial fuel cells in individual and stacked configurations, Bioelectrochemistry, 133, 107459(2020).

187. I. Gajda, J. Greenman, I. Ieropoulos, Microbial Fuel Cell stack performance enhancement through carbon veil anode modification with activated carbon powder, Applied Energy, 262, 114475(2020).

188. M. Oliot, L. Etcheverry, R. Mosdale, A. Bergel, Microbial fuel cells connected in series in a common electrolyte underperform: Understanding why and in what context such a set-up can be applied, Electrochimica Acta, 246, 879-889(2017).

189. Y. Park, S. Park, V. K. Nguyen, J. Yu, C. I. Torres, B. E. Rittmann, T. Lee, Complete nitrogen removal by simultaneous nitrification and denitrification in flat-panel air-cathode microbial fuel cells treating domestic wastewater, Chemical Engineering Journal, 316, 673-679(2017).

190. M. Oliot, L. Etcheverry, A. Mosdale, R. Basseguy, M. L. Délia, A. Bergel, Separator electrode assembly (SEA) with 3-dimensional bioanode and removable air-cathode boosts microbial fuel cell performance, Journal of Power Sources, 356, 389-399(2017).

191.J. An, N. Li, L. Wan, L. Zhou, Q. Du, T. Li, X. Wang, Electric field induced salt precipitation into activated carbon air-cathode causes power decay in microbial fuel cells, Water Research, 123, 369-377(2017).

192. I. Gajda, J. Greenman, C. Melhuish, I. A. Ieropoulos, Electricity and disinfectant production from wastewater: Microbial Fuel Cell as a self-powered electrolyser, Scientific Reports, 6(1), 25571(2016).

193. I. Gajda, J. Greenman, C. Melhuish, I. Ieropoulos, Simultaneous electricity generation and microbially-assisted electrosynthesis in ceramic MFCs, Bioelectrochemistry, 104, 58-64(2015).

194. K. Scott, C. Murano, G. Rimbu, A tubular microbial fuel cell, Journal of Applied Electrochemistry, 37(9), 1063-1068(2007).

195. M. Kadivarian, A. A. Dadkhah, M. Nasr Esfahany, Oily wastewater treatment by a continuous flow microbial fuel cell and packages of cells with serial and parallel flow connections, Bioelectrochemistry, 134, 107535(2020).

196. M. Blatter, L. Delabays, C. Furrer, G. Huguenin, C. P. Cachelin, F. Fischer, Stretched 1000-L microbial fuel cell, Journal of Power Sources, 483, 229130(2021).

197. P. Liang, R. Duan, Y. Jiang, X. Zhang, Y. Qiu, X. Huang, One-year operation of 1000-L modularized microbial fuel cell for municipal wastewater treatment, Water Research, 141, 1-8(2018)

198. X. A. Walter, I. Merino-Jiménez, J. Greenman, I. Ieropoulos, PEE POWER® urinal II - Urinal scale-up with microbial fuel cell scale-down for improved lighting, Journal of Power
Sources, 392, 150-158(2018).

199. Y. Dong, W. He, D. Liang, C. Li, G. Liu, J. Liu, N. Ren, Y. Feng, Operation strategy of cubic-meter scale microbial electrochemistry system in a municipal wastewater treatment plant, Journal of Power Sources, 441, 227124(2019).

200. A. Mohamed, H. M. Zmuda, P. T. Ha, E. R. Coats, H. Beyenal, Large-scale switchable potentiostatically controlled/ microbial fuel cell bioelectrochemical wastewater treatment system, Bioelectrochemistry, 138, 107724(2021).

201. B. E. Logan, Scaling up microbial fuel cells and other bioelectrochemical systems, Applied Microbiology and Biotechnology, 85(6), 1665-1671(2010).

202. H. Hiegemann, D. Herzer, E. Nettmann, M. Lübken, P. Schulte, K.-G. Schmelz, S. Gredigk-Hoffmann, M. Wichern, An integrated $45 \mathrm{~L}$ pilot microbial fuel cell system at a full-scale wastewater treatment plant, Bioresource Technology, 218, 115-122(2016).

203. S. Wu, H. Li, X. Zhou, P. Liang, X. Zhang, Y. Jiang, X. Huang, A novel pilot-scale stacked microbial fuel cell for efficient electricity generation and wastewater treatment, Water Research, 98, 396-403(2016).

204. Y. Dong, Y. Qu, W. He, Y. Du, J. Liu, X. Han, Y. Feng, A 90-liter stackable baffled microbial fuel cell for brewery wastewater treatment based on energy self-sufficient mode, Bioresource Technology, 195, 66-72(2015).

205. E. Cho, D. H. Han, J. Ha, Energy Efficiency Evaluation of Publicly Owned Wastewater Utilities, Journal of Environmental Policy, 11(4), 85-105(2012).

206. K. E. Institute, Construction Technology Digital Library http://218.49.22.39/viewDtlConRpt.do?pMetaCode=OTKCR K200662\&gubun=rpt, (2019).

207. C. Tang, Y. Zhao, C. Kang, Y. Yang, D. Morgan, L. Xu, Towards concurrent pollutants removal and high energy harvesting in a pilot-scale CW-MFC: Insight into the cathode conditions and electrodes connection, Chemical Engineering Journal, 373, 150-160(2019).

208. P. Srivastava, R. Abbassi, V. Garaniya, T. Lewis, A. K. Yadav, Performance of pilot-scale horizontal subsurface flow constructed wetland coupled with a microbial fuel cell for treating wastewater, Journal of Water Process Engineering, 33, 100994(2020).

209. P. Srivastava, A. K. Yadav, V. Garaniya, R. Abbassi, Chapter 6.3 - Constructed Wetland Coupled Microbial Fuel Cell Technology: Development and Potential Applications, Microbial Electrochemical Technology, 1021-1036(2019).

210. O. Guadarrama-Pérez, T. Gutiérrez-Macías, L. García-Sánchez, V. H. Guadarrama-Pérez, E. B. Estrada-Arriaga, Recent advances in constructed wetland-microbial fuel cells for simultaneous bioelectricity production and wastewater treatment: A review, International Journal of Energy Research, 43(10), 5106-5127(2019).

211. T. Gazali and M. A. Moqsud, Evaluation of Scale-Up And Environmental Factors On Microbial Fuel Cell, International Journal on Advanced Science, Engineering and Information Technology, 9, 861(2019). 
212. M. Li, S. Zhou, Y. Xu, Z. Liu, F. Ma, L. Zhi, X. Zhou, Simultaneous $\mathrm{Cr}(\mathrm{VI})$ reduction and bioelectricity generation in a dual chamber microbial fuel cell, Chemical Engineering Journal, 334, 1621-1629(2018).

213. A. Singh and A. Kaushik, Removal of $\mathrm{Cd}$ and $\mathrm{Ni}$ with enhanced energy generation using biocathode microbial fuel cell: Insights from molecular characterization of biofilm communities, Journal of Cleaner Production, 127940(2021).

214.H.-C. Tao, M. Liang, W. Li, L.-J. Zhang, J.-R. Ni, W.-M. $\mathrm{Wu}$, Removal of copper from aqueous solution by electrodeposition in cathode chamber of microbial fuel cell, Journal of hazardous materials, 189(1-2), 186-192(2011).

215. A.-J. Wang, H.-C. Wang, H.-Y. Cheng, B. Liang, W.-Z. Liu, J.-L. Han, B. Zhang, S.-S. Wang, Electrochemistry-stimulated environmental bioremediation: Development of applicable modular electrode and system scale-up, Environmental Science and Ecotechnology, 3, 100050(2020).

216. C. I. Torres, R. Krajmalnik-Brown, P. Parameswaran, A. K. Marcus, G. Wanger, Y. A. Gorby, B. E. Rittmann, Selecting anode-respiring bacteria based on anode potential: phylogenetic, electrochemical, and microscopic characterization, Environmental science \& technology, 43(24), 9519-9524(2009).

217. C. Santoro, A. Serov, R. Gokhale, S. Rojas-Carbonell, L. Stariha, J. Gordon, K. Artyushkova, P. Atanassov, A family of Fe-NC oxygen reduction electrocatalysts for microbial fuel cell (MFC) application: relationships between surface chemistry and performances, Applied Catalysis B: Environmental, 205, 24-33(2017).

218. C. Li, W. He, D. Liang, Y. Tian, D. Li, Y. Yu, Y. Feng, The operation characters of biocathode microbial electrochemical system with microbial separator for domestic wastewater treatment: Power generation, long-term stability, and organic removal, Journal of Power Sources, 495, 229785(2021).

219. J. Sun, Y.-y. Hu, Z. Bi, Y.-q. Cao, Simultaneous decolorization of azo dye and bioelectricity generation using a microfiltration membrane air-cathode single-chamber microbial fuel cell, Bioresource Technology, 100(13), 3185-3192(2009).

220. C. Li, W. He, D. Liang, Y. Tian, R. S. Yadav, J. Liu, Y. Feng, Power density of microbial electrochemical system responds to mass transfer characters of non - ion - selective microbial separator, Bioresource Technology, 311, 123478(2020).

221.T. Tommasi and G. Lombardelli, Energy sustainability of Microbial Fuel Cell (MFC): A case study, Journal of Power Sources, 356, 438-447(2017).

222. H. Hiegemann, T. Littinski, S. Krimmler, M. Lübken, D. Klein, K.-G. Schmelz, K. Ooms, D. Pant, M. Wichern, Performance and inorganic fouling of a submergible $255 \mathrm{~L}$ prototype microbial fuel cell module during continuous long-term operation with real municipal wastewater under practical conditions, Bioresource technology, 294, 122227(2019).

223. S.-E. Oh and B. E. Logan, Voltage reversal during microbial fuel cell stack operation, Journal of Power Sources, 167(1), 11-17(2007)
224. B. Kim, S. V. Mohan, D. Fapyane, I. S. Chang, Controlling voltage reversal in microbial fuel cells, Trends in biotechnology, 38(6), 667-678(2020).

225. J. An, J. Nam, B. Kim, H.-S. Lee, B. H. Kim, I. S. Chang, Performance variation according to anode-embedded orientation in a sediment microbial fuel cell employing a chessboard-like hundred-piece anode, Bioresource technology, 190, 175-181(2015).

226. S. Chen, S. A. Patil, R. K. Brown, U. Schröder, Strategies for optimizing the power output of microbial fuel cells: transitioning from fundamental studies to practical implementation, Applied energy, 233, 15-28(2019).

227. Y. Song, J. An, K. J. Chae, Effect of temperature variation on the performance of microbial fuel cells, Energy Technology, 5(12), 2163-2167(2017).

228. P. Kumar and A. K. Mungray, Microbial fuel cell: optimizing $\mathrm{pH}$ of anolyte and catholyte by using taguchi method, Environmental Progress \& Sustainable Energy, 36(1), 120-128(2017).

229. Y. Ye, H. H. Ngo, W. Guo, S. W. Chang, D. D. Nguyen, Y. Liu, L. D. Nghiem, X. Zhang, J. Wang, Effect of organic loading rate on the recovery of nutrients and energy in a dual-chamber microbial fuel cell, Bioresource technology, 281, 367-373(2019)

230. F. Guo, H. Luo, Z. Shi, Y. Wu, H. Liu, Substrate salinity: A critical factor regulating the performance of microbial fuel cells, a review, Science of The Total Environment, 143021(2020).

231. A. Stefanova, A. Angelov, S. Bratkova, P. Genova, K. Nikolova, Influence of electrical conductivity and temperature in a microbial fuel cell for treatment of mining waste water, Annals of the Constantin Brâncuși University of Târgu Jiu, Letters and Social Science Series, (2018).

232. F. Vicari, S. Mateo, F. Fernandez-Morales, P. Cañizares, A. Galia, O. Scialdone, M. Rodrigo, Influence of the methodology of inoculation in the performance of air-breathing microbial fuel cells, Journal of Electroanalytical Chemistry, 803, 81-88(2017).

233. Y. Ye, H. H. Ngo, W. Guo, S. W. Chang, D. D. Nguyen, X. Zhang, S. Zhang, G. Luo, Y. Liu, Impacts of hydraulic retention time on a continuous flow mode dual-chamber microbial fuel cell for recovering nutrients from municipal wastewater, Science of The Total Environment, 734, 139220(2020).

234. S. Huang, J. Zhang, J. Pi, L. Gong, G. Zhu, Long-term electricity generation and denitrification performance of MFCs with different exchange membranes and electrode materials, Bioelectrochemistry, 140, 107748(2021).

235.Z. Ge and Z. He, Long-term performance of a 200 liter modularized microbial fuel cell system treating municipal wastewater: treatment, energy, cost, Environmental Science: Water Research \& Technology, 2(2), 274-281(2016).

236. E. Zhang, F. Wang, Q. Yu, K. Scott, X. Wang, G. Diao, Durability and regeneration of activated carbon air-cathodes in long-term operated microbial fuel cells, Journal of Power 
Sources, 360, 21-27(2017).

237.R. Valladares Linares, J. Domínguez-Maldonado, E. Rodríguez-Leal, G. Patrón, A. Castillo-Hernández, A. Miranda, D. Diaz Romero, R. Moreno-Cervera, G. Camara-chale, C. G. Borroto, Scale up of microbial fuel cell stack system for residential wastewater treatment in continuous mode operation, Water, 11(2), 217(2019).

238. B. Zhang, H. Zhao, S. Zhou, C. Shi, C. Wang, J. Ni, A novel UASB - MFC - BAF integrated system for high strength molasses wastewater treatment and bioelectricity generation, Bioresource Technology, 100(23), 5687-5693(2009).

239. Y. Ahn and B. E. Logan, Effectiveness of domestic wastewater treatment using microbial fuel cells at ambient and mesophilic temperatures, Bioresource technology, 101(2), 469-475(2010).

240. S. i. Ishii, K. Watanabe, S. Yabuki, B. E. Logan, Y. Sekiguchi, Comparison of electrode reduction activities of Geobacter sulfurreducens and an enriched consortium in an air-cathode microbial fuel cell, Applied and environmental microbiology, 74(23), 7348-7355(2008).

241. J. R. Kim, S. H. Jung, J. M. Regan, B. E. Logan, Electricity generation and microbial community analysis of alcohol powered microbial fuel cells, Bioresource technology, 98(13), 2568-2577(2007).

242. A. A. Yaqoob, M. N. M. Ibrahim, C. Guerrero-Barajas, Modern trend of anodes in microbial fuel cells (MFCs): an overview, Environmental Technology \& Innovation, 101579(2021).

243. Y. Yuan, S. Zhou, Y. Liu, J. Tang, Nanostructured macroporous bioanode based on polyaniline-modified natural loofah sponge for high-performance microbial fuel cells, Environmental science \& technology, 47(24), 14525-14532(2013)

244. J. Zhang, J. Li, D. Ye, X. Zhu, Q. Liao, B. Zhang, Tubular bamboo charcoal for anode in microbial fuel cells, Journal of Power Sources, 272, 277-282(2014).

245. H. Zhu, H. Wang, Y. Li, W. Bao, Z. Fang, C. Preston, O. Vaaland, Z. Ren, L. Hu, Lightweight, conductive hollow fibers from nature as sustainable electrode materials for microbial energy harvesting, Nano Energy, 10, 268-276(2014).

246. Y. Yuan, T. Liu, P. Fu, J. Tang, S. Zhou, Conversion of sewage sludge into high-performance bifunctional electrode materials for microbial energy harvesting, Journal of Materials Chemistry A, 3(16), 8475-8482(2015).

247. S. Chen, J. Tang, X. Jing, Y. Liu, Y. Yuan, S. Zhou, A hierarchically structured urchin-like anode derived from chestnut shells for microbial energy harvesting, Electrochimica Acta, 212, 883-889(2016).

248. X. Ma, C. Feng, W. Zhou, H. Yu, Municipal sludge-derived carbon anode with nitrogen-and oxygen-containing functional groups for high-performance microbial fuel cells, Journal of Power Sources, 307, 105-111(2016).

249. H. Feng, Y. Jia, D. Shen, Y. Zhou, T. Chen, W. Chen, Z. Ge, S. Zheng, M. Wang, The effect of chemical vapor deposition temperature on the performance of binder-free sewage sludge-derived anodes in microbial fuel cells, Science of The Total Environment, 635, 45-52(2018).

250. H. Yuan, G. Dong, D. Li, L. Deng, P. Cheng, Y. Chen,
Steamed cake-derived 3D carbon foam with surface anchored carbon nanoparticles as freestanding anodes for high-performance microbial fuel cells, Science of the Total Environment, 636, 1081-1088(2018).

251.L. Zeng, S. Zhao, M. He, Macroscale porous carbonized polydopamine-modified cotton textile for application as electrode in microbial fuel cells, Journal of Power Sources, 376, 33-40(2018).

252. N. Senthilkumar, M. Pannipara, A. G. Al-Sehemi, PEDOT/ $\mathrm{NiFe} 2 \mathrm{O} 4$ nanocomposites on biochar as a free-standing anode for high-performance and durable microbial fuel cells, New Journal of Chemistry, 43(20), 7743-7750(2019).

253. Y.-H. Hung, T.-Y. Liu, H.-Y. Chen, Renewable coffee waste-derived porous carbons as anode materials for high-performance sustainable microbial fuel cells, ACS Sustainable Chemistry \& Engineering, 7(20), 16991-16999 (2019).

254. A. Mehdinia, E. Ziaei, A. Jabbari, Facile microwave-assisted synthesized reduced graphene oxide/tin oxide nanocomposite and using as anode material of microbial fuel cell to improve power generation, International journal of hydrogen energy, 39(20), 10724-10730(2014).

255. X. Y. Wu, F. Tong, T. S. Song, X. Y. Gao, J. J. Xie, C. C. Zhou, L. X. Zhang, P. Wei, Effect of zeolite coated anode on the performance of microbial fuel cells, Journal of Chemical Technology \& Biotechnology, 90(1), 87-92(2015).

256. C. Zhang, P. Liang, Y. Jiang, X. Huang, Enhanced power generation of microbial fuel cell using manganese dioxide-coated anode in flow-through mode, Journal of Power Sources, 273, 580-583(2015).

257. X. Quan, B. Sun, H. Xu, Anode decoration with biogenic Pd nanoparticles improved power generation in microbial fuel cells, Electrochimica Acta, 182, 815-820(2015).

258. L. Huang, X. Li, Y. Ren, X. Wang, In-situ modified carbon cloth with polyaniline/graphene as anode to enhance performance of microbial fuel cell, international journal of hydrogen energy, 41(26), 11369-11379(2016).

259. M. Harshiny, N. Samsudeen, R. J. Kameswara, M. Matheswaran, Biosynthesized FeO nanoparticles coated carbon anode for improving the performance of microbial fuel cell, international journal of hydrogen energy, 42(42), 26488-26495(2017).

260. L. Zou, Z. Lu, Y. Huang, Z.-e. Long, Y. Qiao, Nanoporous $\mathrm{Mo}_{2} \mathrm{C}$ functionalized 3D carbon architecture anode for boosting flavins mediated interfacial bioelectrocatalysis in microbial fuel cells, Journal of Power Sources, 359, 549-555(2017).

261. H. O. Mohamed, M. A. Abdelkareem, M. Obaid, S.-H. Chae, M. Park, H. Y. Kim, N. A. Barakat, Cobalt oxides-sheathed cobalt nano flakes to improve surface properties of carbonaceous electrodes utilized in microbial fuel cells, Chemical Engineering Journal, 326, 497-506(2017).

262. W. Zhang, B. Xie, L. Yang, D. Liang, Y. Zhu, H. Liu, Brush-like polyaniline nanoarray modified anode for improvement of power output in microbial fuel cell, Bioresource technology, 233, 291-295(2017). 
263. H. Xu, X. Quan, Z. Xiao, L. Chen, Effect of anodes decoration with metal and metal oxides nanoparticles on pharmaceutically active compounds removal and power generation in microbial fuel cells, Chemical Engineering Journal, 335, 539-547(2018).

264. J. M. Sonawane, S. Al-Saadi, R. K. Singh Raman, P. C. Ghosh, S. B. Adeloju, Exploring the use of polyaniline-modified stainless steel plates as low-cost, high-performance anodes for microbial fuel cells, Electrochimica Acta, 268, 484-493(2018).

265. J. Tang, Y. Yuan, T. Liu, S. Zhou, High-capacity carbon-coated titanium dioxide core - shell nanoparticles modified three dimensional anodes for improved energy output in microbial fuel cells, Journal of Power Sources, 274, 170-176(2015).

266.X. Yang, X. Ma, K. Wang, D. Wu, Z. Lei, C. Feng, Eighteen-month assessment of 3D graphene oxide aerogel-modified 3D graphite fiber brush electrode as a high-performance microbial fuel cell anode, Electrochimica Acta, 210, 846-853(2016).

267. J. Chen, Y. Hu, X. Tan, L. Zhang, W. Huang, J. Sun, Enhanced performance of microbial fuel cell with in situ preparing dual graphene modified bioelectrode, Bioresource Technology, 241, 735-742(2017).

268. Q.-Q. Wang, X.-Y. Wu, Y.-Y. Yu, D.-Z. Sun, H.-H. Jia, Y.-C. Yong, Facile in-situ fabrication of graphene/riboflavin electrode for microbial fuel cells, Electrochimica Acta, 232, 439-444(2017).

269. Y. Cheng, M. Mallavarapu, R. Naidu, Z. Chen, In situ fabrication of green reduced graphene-based biocompatible anode for efficient energy recycle, Chemosphere, 193, 618-624(2018).

270. D. Paul, M. T. Noori, P. P. Rajesh, M. M. Ghangrekar, A. Mitra, Modification of carbon felt anode with graphene oxide-zeolite composite for enhancing the performance of microbial fuel cell, Sustainable Energy Technologies and Assessments, 26, 77-82(2018).

271. X.-Q. Lin, Z.-L. Li, B. Liang, J. Nan, A.-J. Wang, Identification of biofilm formation and exoelectrogenic population structure and function with graphene/polyanliline modified anode in microbial fuel cell, Chemosphere, 219, 358-364(2019).

272.J. Y. Chen, P. Xie, Z. P. Zhang, Reduced graphene oxide/polyacrylamide composite hydrogel scaffold as biocompatible anode for microbial fuel cell, Chemical Engineering Journal, 361, 615-624(2019).

273. Y. Li, J. Liu, X. Chen, X. Yuan, N. Li, W. He, Y. Feng, Enhanced electricity generation and extracellular electron transfer by polydopamine-reduced graphene oxide (PDA-rGO) modification for high-performance anode in microbial fuel cell, Chemical Engineering Journal, 387, 123408(2020).

274. J. R. Kim, J.-Y. Kim, S.-B. Han, K.-W. Park, G. Saratale, S.-E. Oh, Application of Co-naphthalocyanine (CoNPc) as alternative cathode catalyst and support structure for microbial fuel cells, Bioresource technology, 102(1), 342-347(2011).

275. B. Mecheri, A. Iannaci, A. D'Epifanio, A. Mauri, S. Licoccia, Carbon-supported zirconium oxide as a cathode for microbial fuel cell applications, ChemPlusChem, 81(1), 80(2016).

276. M. Ghasemi, W. R. W. Daud, M. Rahimnejad, M. Rezayi, A. Fatemi, Y. Jafari, M. Somalu, A. Manzour,
Copper-phthalocyanine and nickel nanoparticles as novel cathode catalysts in microbial fuel cells, International Journal of hydrogen energy, 38(22), 9533-9540(2013).

277. X. Zhang, X. Xia, I. Ivanov, X. Huang, B. E. Logan, Enhanced activated carbon cathode performance for microbial fuel cell by blending carbon black, Environmental science \& technology, 48(3), 2075-2081(2014).

278. L. Feng, Y. Chen, L. Chen, Easy-to-operate and low-temperature synthesis of gram-scale nitrogen-doped graphene and its application as cathode catalyst in microbial fuel cells, ACS nano, 5(12), 9611-9618(2011).

279. D. Li, J. Liu, H. Wang, Y. Qu, Y. Feng, Effect of long-term operation on stability and electrochemical response under water pressure for activated carbon cathodes in microbial fuel cells, Chemical Engineering Journal, 299, 314-319(2016).

280. X. Zhang, D. Pant, F. Zhang, J. Liu, W. He, B. E. Logan, Long term performance of chemically and physically modified activated carbons in air cathodes of microbial fuel cells, ChemElectroChem, 1(11), 1859-1866(2014).

281. W. Yang, F. Zhang, W. He, J. Liu, M. A. Hickner, B. E. Logan, Poly (vinylidene fluoride-co-hexafluoropropylene) phase inversion coating as a diffusion layer to enhance the cathode performance in microbial fuel cells, Journal of Power Sources, 269, 379-384(2014).

282. X. Li, X. Wang, Y. Zhang, N. Ding, Q. Zhou, Opening size optimization of metal matrix in rolling-pressed activated carbon air-cathode for microbial fuel cells, Applied Energy, 123, 13-18(2014).

283. L. Xiao, J. Damien, J. Luo, H. D. Jang, J. Huang, Z. He, Crumpled graphene particles for microbial fuel cell electrodes, Journal of Power Sources, 208, 187-192(2012).

284. S. Khilari, S. Pandit, M. Ghangrekar, D. Das, D. Pradhan, Graphene supported a-MnO 2 nanotubes as a cathode catalyst for improved power generation and wastewater treatment in single-chambered microbial fuel cells, Rsc Advances, 3(21), 7902-7911(2013).

285.Z. Yan, M. Wang, Y. Lu, R. Liu, J. Zhao, Ethylene glycol stabilized $\mathrm{NaBH} 4$ reduction for preparation carbon-supported $\mathrm{Pt}-\mathrm{Co}$ alloy nanoparticles used as oxygen reduction electrocatalysts for microbial fuel cells, Journal of Solid State Electrochemistry, 18(4), 1087-1097(2014).

286. C. J. Kirubaharan, D. J. Yoo, A. R. Kim, Graphene/poly (3, 4-ethylenedioxythiophene) $/ \mathrm{Fe}_{3} \mathrm{O}_{4} \quad$ nanocomposite - An efficient oxygen reduction catalyst for the continuous electricity production from wastewater treatment microbial fuel cells, International Journal of Hydrogen Energy, 41(30), 13208-13219(2016).

287. Q. Wen, S. Wang, J. Yan, L. Cong, Z. Pan, Y. Ren, Z. Fan, $\mathrm{MnO}_{2}$ - graphene hybrid as an alternative cathodic catalyst to platinum in microbial fuel cells, Journal of power sources, 216, 187-191(2012).

288.Z. Yan, M. Wang, B. Huang, J. Zhao, R. Liu, Carboxyl multi-wall carbon nanotubes supported $\mathrm{Pt}-\mathrm{Ni}$ alloy nanoparticles as cathode catalyst for microbial fuel cells, Int. J. Electrochem. Sci, 7, 10825-10834(2012). 
289. N. Zhu, J. Huang, W. Shen, L. Tu, P. Wu, H. Ma, Carboxylic carbon nanotube: Catalyst support material and oxygen reduction reaction of microbial fuel cells, Int. J. Electrochem. Sci, 10, 2634-2645(2015).

290.L. Tan, Z.-Q. Liu, N. Li, J.-Y. Zhang, L. Zhang, S. Chen, $\mathrm{CuSe}$ decorated carbon nanotubes as a high performance cathode catalyst for microbial fuel cells, Electrochimica Acta, 213, 283-290(2016).

291. Y.-C. Song, J.-H. Woo, K. Yoo, J.-W. Chung, C.-Y. Lee, Dual layered CNT structure air cathode for power generation from microbial fuel cells, KSCE Journal of Civil Engineering, 17(4), 646-650(2013).

292. X. Shi, Y. Feng, X. Wang, H. Lee, J. Liu, Y. Qu, W. He, S. S. Kumar, N. Ren, Application of nitrogen-doped carbon powders as low-cost and durable cathodic catalyst to aircathode microbial fuel cells, Bioresource technology, 108, 89-93(2012).

293. L. Feng, L. Yang, Z. Huang, J. Luo, M. Li, D. Wang, Y. Chen, Enhancing electrocatalytic oxygen reduction on nitrogen-doped graphene by active sites implantation, Scientific reports, 3(1), 1-8(2013).

294. Y. Su, Y. Zhu, X. Yang, J. Shen, J. Lu, X. Zhang, J. Chen, C. Li, A highly efficient catalyst toward oxygen reduction reaction in neutral media for microbial fuel cells, Industrial \& Engineering Chemistry Research, 52(18), 6076-6082(2013).

295. Y. Ahn, I. Ivanov, T. C. Nagaiah, A. Bordoloi, B. E. Logan, Mesoporous nitrogen-rich carbon materials as cathode catalysts in microbial fuel cells, Journal of Power Sources, 269, 212-215(2014).

296. L. Feng, Y. Yan, Y. Chen, L. Wang, Nitrogen-doped carbon nanotubes as efficient and durable metal-free cathodic catalysts for oxygen reduction in microbial fuel cells, Energy \& Environmental Science, 4(5), 1892-1899(2011).

297. G. Yue, K. Meng, Q. Liu, One-step synthesis of N-doped carbon and its application as a cost-efficient catalyst for the oxygen reduction reaction in microbial fuel cells, ChemPlusChem, 80(7), 1133(2015).

298. Q. Wen, S. Wang, J. Yan, L. Cong, Y. Chen, H. Xi, Porous nitrogen-doped carbon nanosheet on graphene as metal-free catalyst for oxygen reduction reaction in air-cathode microbial fuel cells, Bioelectrochemistry, 95, 23-28(2014).

299. Y. Liu, K. Li, Y. Liu, L. Pu, Z. Chen, S. Deng, The high-performance and mechanism of P-doped activated carbon as a catalyst for air-cathode microbial fuel cells, Journal of Materials Chemistry A, 3(42), 21149-21158(2015).

300. H. Yuan, Y. Hou, Z. Wen, X. Guo, J. Chen, Z. He, Porous carbon nanosheets codoped with nitrogen and sulfur for oxygen reduction reaction in microbial fuel cells, ACS applied materials \& interfaces, 7(33), 18672-18678(2015).

301. D. L. Hoskins, X. Zhang, M. A. Hickner, B. E. Logan, Spray-on polyvinyl alcohol separators and impact on power production in air-cathode microbial fuel cells with different solution conductivities, Bioresource technology, 172, 156-161(2014).

302. J. Chouler, I. Bentley, F. Vaz, A. O'Fee, P. J. Cameron, M.
Di Lorenzo, Exploring the use of cost-effective membrane materials for Microbial Fuel Cell based sensors, Electrochimica Acta, 231, 319-326(2017).

303. H. Ilbeygi, M. Ghasemi, D. Emadzadeh, A. F. Ismail, S. Zaidi, S. A. Aljlil, J. Jaafar, D. Martin, S. Keshani, Power generation and wastewater treatment using a novel SPEEK nanocomposite membrane in a dual chamber microbial fuel cell, International Journal of Hydrogen Energy, 40(1), 477-487(2015).

304. A. Sivasankaran, D. Sangeetha, Y.-H. Ahn, Nanocomposite membranes based on sulfonated polystyrene ethylene butylene polystyrene (SSEBS) and sulfonated $\mathrm{SiO}_{2}$ for microbial fuel cell application, Chemical Engineering Journal, 289, 442-451(2016).

305. S. Ayyaru and S. Dharmalingam, A study of influence on nanocomposite membrane of sulfonated $\mathrm{TiO}_{2}$ and sulfonated polystyrene-ethylene-butylene-polystyrene for microbial fuel cell application, Energy, 88, 202-208(2015).

306. E. Mahendiravarman and D. Sangeetha, Increased microbial fuel cell performance using quaternized poly ether ether ketone anionic membrane electrolyte for electricity generation, International journal of hydrogen energy, 38(5), 2471-2479(2013).

307. M. Elangovan and S. Dharmalingam, Preparation and performance evaluation of poly (ether-imide) based anion exchange polymer membrane electrolyte for microbial fuel cell, International Journal of Hydrogen Energy, 41(20), 8595-8605(2016).

308. M. Elangovan and S. Dharmalingam, A facile modification of a polysulphone based anti biofouling anion exchange membrane for microbial fuel cell application, RSC advances, 6(25), 20571-20581(2016).

309. S. Pandit, A. Sengupta, S. Kale, D. Das, Performance of electron acceptors in catholyte of a two-chambered microbial fuel cell using anion exchange membrane, Bioresource technology, 102(3), 2736-2744(2011).

310. A. E. Inglesby and A. C. Fisher, Downstream application of a microbial fuel cell for energy recovery from an Arthrospira maxima fed anaerobic digester effluent, RSC advances, 3(38), 17387-17394(2013).

311. J. Ma, Z. Wang, D. Suor, S. Liu, J. Li, Z. Wu, Temporal variations of cathode performance in air-cathode single-chamber microbial fuel cells with different separators, Journal of Power Sources, 272, 24-33(2014).

312. I. Satar, W. R. W. Daud, B. H. Kim, M. R. Somalu, M. Ghasemi, M. H. A. Bakar, T. Jafary, S. N. Timmiati, Performance of titanium-nickel (Ti/Ni) and graphite felt-nickel (GF/Ni) electrodeposited by $\mathrm{Ni}$ as alternative cathodes for microbial fuel cells, Journal of the Taiwan Institute of Chemical Engineers, 89, 67-76(2018).

313. S. P. Jung, E. Kim, B. Koo, Effects of wire-type and mesh-type anode current collectors on performance and electrochemistry of microbial fuel cells, Chemosphere, 209, 542-550(2018).

314. J. R. Kim, J. Rodríguez, F. R. Hawkes, R. M. Dinsdale, A. 
J. Guwy, G. C. Premier, Increasing power recovery and organic removal efficiency using extended longitudinal tubular microbial fuel cell (MFC) reactors, Energy \& Environmental Science, 4(2), 459-465(2011).

315.Z. Li, L. Yao, L. Kong, H. Liu, Electricity generation using a baffled microbial fuel cell convenient for stacking, Bioresource Technology, 99(6), 1650-1655(2008).

316. F. Zhang, Z. Ge, J. Grimaud, J. Hurst, Z. He, In situ investigation of tubular microbial fuel cells deployed in an aeration tank at a municipal wastewater treatment plant, Bioresource technology, 136, 316-321(2013).

317. A. Gálvez, J. Greenman, I. Ieropoulos, Landfill leachate treatment with microbial fuel cells; scale-up through plurality, Bioresource technology, 100(21), 5085-5091(2009).

318. P. Liang, M. Fan, X. Cao, X. Huang, Evaluation of applied cathode potential to enhance biocathode in microbial fuel cells, Journal of Chemical Technology \& Biotechnology: International Research in Process, Environmental \& Clean Technology, 84(5), 794-799(2009).

319.F. Zhang, Z. Ge, J. Grimaud, J. Hurst, Z. He, Long-term performance of liter-scale microbial fuel cells treating primary effluent installed in a municipal wastewater treatment facility, Environmental science \& technology, 47(9), 4941-4948(2013).

320. A. Ter Heijne, F. Liu, L. S. Van Rijnsoever, M. Saakes, H. V. Hamelers, C. J. Buisman, Performance of a scaled-up Microbial Fuel Cell with iron reduction as the cathode reaction, Journal of Power Sources, 196(18), 7572-7577(2011).
321. P. Clauwaert, S. Mulenga, P. Aelterman, W. Verstraete, Litre-scale microbial fuel cells operated in a complete loop, Applied microbiology and biotechnology, 83(2), 241-247 (2009).

\section{Declaration of Competing Interest}

The authors declare that they have no known competing financial interests or personal relationships that could have appeared to influence the work reported in this paper.

\section{Authors and Contribution Statement}

\section{Sunghoon Son}

Ph.D student, ORCID (10 0000-0002-1829-2422

\section{Youngjin Kim}

Professor, ORCID 두 0000-0002-6034-015X

\section{Myeongwoon Kim}

Professor, ORCID 다 0000-0001-9667-2968

Sokhee P. Jung

Professor, ORCID (D) 0000-0002-3566-5649 